SIMONE TESSARO

ESTUDO DA COMUNIDADE DE BACTÉRIAS METANOTRÓFICAS

EM UMA CRONOSSEQUÊNCIA DE SOLOS DA AMAZÔNIA

Dissertação apresentada ao Programa de PósGraduação em Microbiologia do Instituto de Ciências Biomédicas da Universidade de São Paulo, para obtenção do título de Mestre em Ciências. 
SIMONE TESSARO

\section{ESTUDO DA COMUNIDADE DE BACTÉRIAS METANOTRÓFICAS \\ EM UMA CRONOSSEQUÊNCIA DE SOLOS DA AMAZÔNIA}

Dissertação apresentada ao Programa de PósGraduação em Microbiologia do Instituto de Ciências Biomédicas da Universidade de São Paulo, para obtenção do título de Mestre em Ciências.

Área de concentração: Microbiologia

Orientadora: Dra. Vivian Helena Pellizari

Versão corrigida. A versão original eletrônica encontra se disponível tanto na Biblioteca do ICB quanto na Biblioteca Digital de Teses e Dissertações da USP (BDTD) 


\footnotetext{
DADOS DE CATALOGAÇÃO NA PUBLICAÇÃO (CIP)

Serviço de Biblioteca e Informação Biomédica do Instituto de Ciências Biomédicas da Universidade de São Paulo
}

reprodução não autorizada pelo autor

Tessaro, Simone.

Estudo da comunidade de bactérias metanotróficas em uma cronossequência de solos da Amazônia / Simone Tessaro. -- São Paulo, 2012.

Orientador: Profa. Dra. Vivian Helena Pellizari.

Dissertação (Mestrado) - Universidade de São Paulo. Instituto de Ciências Biomédicas. Departamento de Microbiologia. Área de concentração: Microbiologia. Linha de pesquisa: Diversidade Microbiana.

Versão do título para o inglês: Study of metanotrophic community present in chronosequence soils from Amazônia.

1. Amazônia 2. Uso do solo 3. Bactérias metanotróficas 4. Oxidação de metano 5. Gene pmoA 6. Pasture I. Pellizari, Profa. Dra. Vivian Helena II. Universidade de São Paulo. Instituto de Ciências Biomédicas. Programa de Pós-Graduação em Microbiologia III. Título. 


\section{Candidato(a): $\quad$ Simone Tessaro.}

Título da Dissertação: $\quad$ Estudo da comunidade de bactérias metanotróficas em uma cronossequência de solos da Amazônia.

Orientador(a): $\quad$ Profa. Dra. Vivian Helena Pellizari.

A Comissão Julgadora dos trabalhos de Defesa da Dissertação de Mestrado, em sessão pública realizada a ..............................................., considerou
( ) Aprovado(a)
( ) Reprovado(a)

Examinador(a): Assinatura:

Nome:

Instituição:

Examinador(a): Assinatura:

Nome:

Instituição:

Presidente: Assinatura:

Nome:

Instituição: 


\section{CERTIFICADO DE ISENÇÃO}

Certificamos que o Protocolo CEP-ICB N N $^{\circ}$ 77/10 referente ao projeto intitulado: "Estudo da diversidade de bactérias metanotróficas em solos da Amazônia submetidos à conversão a solo de pastagem" sob a responsabilidade de Simone Tessaro, foi analisado na presente data pela CEUA - COMISSÃO DE ÉTICA NO USO DE ANIMAIS e pela CEPSH- COMISSÃO DE Ética EM PESQuisa COM SEREs humanos, tendo sido deliberado que o referido projeto não envolve manipulação animal ou humana que justifique uma aprovação quanto aos princípios éticos exigidos por ambas as Comissões.

São Paulo, 20 de abril de 2010.

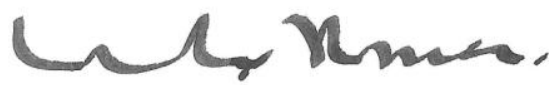

PROF. DR. WOTHAN TAVARES DE LIMA Coordenador da CEUA - ICB/USP

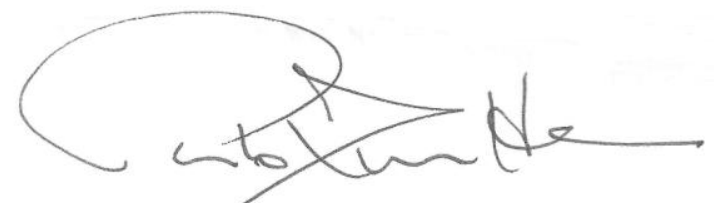

PROF. DR. PAOLO M.A ZANOTTO Vice-Coordenador da CEPsh - ICB/USP 
Aos meus pais Lurdes e Wilson, que foram à base da minha educação.

Ao meu irmão Paulo e minha cunhada Jane pelo incentivo e companheirismo em todos os momentos.

Ao meu marido Octavio, pela compreensão, carinho e dedicação.

A toda a família pela torcida... 


\section{AGRADECIMENTOS}

A realização deste trabalho só foi possível graças à colaboração, de forma direta ou indireta, de várias pessoas e instituições, às quais gostaria de exprimir meu profundo respeito e agradecimento.

À minha orientadora, Dra. Vivian Helena Pellizari, pela oportunidade, apoio e orientação em todas as fases deste trabalho, pela compreensão e amizade a mim dedicados.

À Dra. Cristina Rossi Nakayama, a Cris, pelos preciosos ensinamentos, e pelo carinho e apoio de sempre.

À Dra. Cláudia Echevenguá Teixeira, minha amiga Cláudia, pelo carinho, dedicação e por me estimular a procurar novos caminhos.

À Msc. Rosa de Carvalho Gamba, a Rosinha, pela sabedoria, disposição e incentivo em todos os momentos.

À colega de laboratório e amiga do coração, Daniella Vilela de Lima, pela sua amizade, por toda sua dedicação, ajuda e disponibilidade em todos os momentos, e claro por ser minha companheira de longas horas de laboratório.

Aos grandes amigos que fiz no Laboratório de Ecologia de Micro-organismos, pelos incansáveis momentos de ajuda. Ana Carol, (Aniiiiiiiiiiiinha), Rubens Duarte, Débora Linhares, Priscila Ikeda, Fabiana Paula, Adriana Lopes, Adriana Torres, André Rosh, Diego Castillo, Felipe Nóbrega. Obrigada pela prestatividade, disponibilidade e por não medirem esforços em ajudar. Obrigada também pelos momentos de alegria e convivência no laboratório e fora dele!

À Fundação de Amparo a pesquisa do Estado de São Paulo (FAPESP), pelo suporte financeiro e concessão da bolsa de mestrado, processo: 2010/06710-1

À Universidade de São Paulo, pela oportunidade.

Aos professores e funcionários do ICB/USP meus agradecimentos por toda a ajuda prestada. 
À todos integrantes do projeto ARMO -“Amazon Rainforest Microbial Observatory”, pela possibilidade de fazer parte deste grupo.

Ao Octavio Luz, pelo carinho, incentivo e constante encorajamento a fim de prosseguir a elaboração deste trabalho, enfim por acreditar que seria possível.

À minha família pelo apoio e incentivo, e por compreenderem muitas vezes a minha ausência nos momentos de encontro familiar.

E a todos aqueles que, embora não mencionados, contribuíram de alguma forma para a realização deste trabalho.

Meus sinceros agradecimentos! 
"A vitalidade é demonstrada não apenas pela persistência, mas pela capacidade de começar de novo"

Scott Fitzgerald 


\section{RESUMO}

TESSARO, S. Estudo da comunidade de bactérias metanotróficas em uma cronossequência de solos da Amazônia. 2012. 94 f. Dissertação (Mestrado em Microbiologia) - Instituto de Ciências Biomédicas, Universidade de São Paulo, São Paulo, 2012.

Bactérias metanotróficas são conhecidas por utilizarem o metano como única fonte de carbono e energia, e possuírem importante papel na regulação do fluxo líquido de metano entre o solo e a atmosfera. O gás metano é um dos principais gases que contribuem para o efeito estufa no planeta, tendo uma ação 25 vezes maior do que a do $\mathrm{CO}_{2}$, em relação à retenção do calor. A Amazônia possui importante papel no ciclo global do carbono, possuindo um significativo reservatório desse composto. $\mathrm{O}$ desmatamento da floresta original para conversão a pastagem é dos principais problemas enfrentados pela Amazônia. As mudanças no uso do solo levam a alterações na comunidade microbiana, podendo alterar as suas funções. O objetivo deste trabalho foi pesquisar a presença e a diversidade metanotrófica a partir de amostras de uma cronossequência de solos da Amazônia, onde ocorreu conversão de floresta à pastagem, e posteriormente a vegetação secundária, e verificar se tal manejo do solo influencia na estrutura da comunidade metanotrófica. Para isso técnicas de cultivo e enriquecimento, construção de bibliotecas do gene $p m o A$ e a aplicação da técnica de DNA-SIP foram utilizadas. A partir de amostras de solo de floresta primária, secundária e de pastagens, foram realizados enriquecimentos com a finalidade de avaliar o consumo de metano, e realizar extração do DNA total para construir bibliotecas do gene funcional pmoA para o estudo da comunidade metanotrófica. Uma amostra de pastagem foi também utilizada para a aplicação da técnica de DNA-SIP ${ }^{13} \mathrm{CH}_{4}$, resultando na análise de sequências de três bibliotecas do gene rRNA $16 \mathrm{~S}$. As bibliotecas do gene $p m o A$ indicaram a presença de bactérias metanotróficas das Famílias Methylocystaceae e Methylococcaceae, sendo que a maioria das sequências obtidas foram agrupadas com sequências relacionadas à família Methylocystaceae e ao gênero Methylocaldum. Os resultados da avaliação de consumo de metano demonstram que a comunidade consumidora de metano está ativa para todas as amostras avaliadas. No experimento de DNA-SIP ${ }^{13} \mathrm{CH}_{4}$, a recuperação do DNA marcado ocorreu após o consumo de $0,6 \mathrm{mmol}$ de metano no microcosmo do tempo de incubação t2. As bibliotecas do gene rRNA $16 \mathrm{~S}$ do DNA total do solo revelaram a presença bactérias distribuídas por diversos Filos relacionados a solo. Nas bibliotecas construídas a partir do DNA em que foi incorporado o ${ }^{13} \mathrm{CH}_{4}$, foram identificados micro-organismos relacionados ao ciclo do metano, como as metanotróficas pertecentes as famílias Methylocystaceae e Methylococcaceae, além de outros grupos de micro-organismos cujo papel no ciclo do metano não é totalmente conhecido, como os pertecentes a família Methylophilaceae e ao Filo Armatimonadetes (OP10). Apesar de incerto o processo de como ocorre à utilização dos metabólitos da oxidação do metano por estes micro-organismos, a presença destes no ambiente pode ser de grande importância.

Palavras-chave: Bactérias metanotróficas. Oxidação do metano. Uso do solo. Amazônia. Pastagem. Gene pmoA. 


\begin{abstract}
TESSARO, S. Study of the methanotrophic community present in chronosequence soils from Amazon. 2012. 94 p. Masters thesis (Microbiology) - Instituto de Ciências Biomédicas, Universidade de São Paulo, São Paulo, 2012.

Methanotrophic bacteria are known to utilize methane as a single source of carbon and energy, and have an important role in regulating methane flux between soil and atmosphere. Methane is a major gas contributing to global warming on Earth, taking an action 25 times greater than $\mathrm{CO}_{2}$, relative to heat retention. The Amazon forest plays an important role in the global carbon cycle, having a significant carbon reservoir. Deforestation of the original forest for the conversion to pasture is a major problem faced by the Amazon forest. Changes in land use lead to changes in soil microbial community, altering the functions of this community. The objective of this study was to investigate the presence and the diversity of methanotrophic bacteria in samples of Amazon forest chronosequence soils, where there have been a conversion of forest to pasture, and then to secondary forest, and verify if such soil management influences the structure of the methanotrophic community. Enrichment and cultivation techniques, gene libraries of $p m o A$ gene and application of the DNA-SIP technique were used to achieve this goal. From primary, secondary forest and pasture soil samples, enrichments were performed in order to evaluate the consumption of methane. Functional gene $p m o A$ libraries werw constructed from total DNA extracted from soils in order to study the methanotrophic community. A pasture sample was used in the DNA-SIP ${ }^{13} \mathrm{CH}_{4}$ technique, resulting in three sequence analysis of $16 \mathrm{~S}$ rRNA gene libraries. The $p m o A$ gene libraries indicated the presence of methanotrophic bacteria from Families Methylocystaceae and Methylococcaceae, and most of the sequences were grouped with sequences related to Methylocystaceae Family and Methylocaldum. The evaluation of methane consumption showed that the methane consuming community is active for all samples. In the DNA-SIP ${ }^{13} \mathrm{CH}_{4}$ experiment, the recovery of labeled DNA occurred after $0.6 \mathrm{mmol}$ of methane were consumed in the microcosm, - incubation time t2. Gene libraries of rRNA 16S from total DNA of soil, revealed the presence of bacteria over several Phyla related to soil. In gene libraries constructed from labeled DNA, methane cycle microorganisms were identified such as the Methylocystaceae, and Methylococcaceae methanotrophic Families. Other groups of microorganisms like Methylophilaceae Family and Armatimonadetes Phylum (OP10) bacteria were also found, but their role in the methane cycle is not fully understood. The knowledge about the process of metabolites from the methane oxidation by these microorganisms may be uncertain, although the presence of this microorganisms in the environment may be important.
\end{abstract}

Keywords: Methanotrophic bacteria. Methane oxidation. Amazon. Soil use. Pastures. pmoA gene. 


\section{LISTA DE ILUSTRAÇÕES}

Figura 1 - Mapa do desmatamento acumulado no bioma Amazônia até 2010

Figura 2 - Esquema resumido do ciclo do metano, incluindo produção e consumo.

Figura 3 - Esquema do metabolismo da oxidação biológica do metano .27

Figura 4 - Estruturas de Methylocystis sp. apresentando as subunidades de pMMO .29

Figura 5 - Mapa com a localização da Fazenda NovaVida .34

Figura 6 - Esquema da cronossequência do solo amostrado.

Figura 7 - Imagem de satélite da Fazenda Nova Vida, com a localização dos cinco sítios de amostragem.

Figura 8 - Fluxograma da metodologia empregada para o estudo da comunidade metanotrófica em solos da Amazônia.

Figura 9 - Sistema de distribuição simultânea de gases, usado para a manipulação de micro-organismos metanotróficos - Laboratório de Ecologia de Microorganismos.

Figura 10 - Fluxograma da metodologia empregada na aplicação da técnica de DNA-SIP ${ }^{13}$ $\mathrm{CH}_{4}$

Figura 11 -Esquema simplificado dos microcosmos realizados para o emprego da técnica de DNA-SIP.

Figura 12 - Esquema simplificado do processamento do DNA obtido das frações do DNASIP.......

Figura 13 - NMDS da estrutura da comunidade oxidadora de metano, determinada por DGGE e correlação com variáveis ambientais

Figura 14 - Avaliação do consumo de metano por cromatografia gasosa. O consumo de metano está apresentado em mmol.

Figura 15 - Árvore filogenética baseada no alinhamento de sequências de aminoácidos do fragmento pmoA amplificado com os primers A189F e mb661R, e sequências referência adquiridas no GeneBank.....

Figura 16 - Representação gráfica mostrando a curva de consumo e realimentação de ${ }^{12} \mathrm{CH}_{4}(\mathrm{a}) \mathrm{e}{ }^{13} \mathrm{CH}_{4}$ (b) dos pares de frascos.

Figura 17 - Consumo acumulado de metano em cada frasco de enriquecimento. Os frascos foram incubados com ${ }^{12} \mathrm{CH}_{4}$, e incubados com ${ }^{13} \mathrm{CH}_{4}$ 
Figura 18 - Quantidades de DNA normalizadas para cada uma das frações, tanto para as relativas aos enriquecimentos com ${ }^{12} \mathrm{CH}_{4}\left({ }^{12} \mathrm{C}\right.$-DNA linha vermelha), quanto as relativas ao enriquecimento com ${ }^{13} \mathrm{CH}_{4}\left({ }^{13} \mathrm{C}\right.$-DNA linha azul).

Figura 19 - Árvore filogenética baseada no alinhamento de sequências do gene rRNA 16S, obtidas a partir do DNA da amostra original ( $\mathrm{t} 0$ )

Figura 20 - Árvore filogenética baseada no alinhamento de sequências do gene rRNA 16S, obtidas a partir do DNA recuperado dos enriquecimento com metano marcado, temp de incubação $\mathrm{t} 2$-fração 9

Figura 21 - Árvore filogenética baseada no alinhamento de sequências do gene rRNA 16S, obtidas a partir do DNA recuperado dos enriquecimento com metano marcado, tempo de incubação $\mathbf{2} 2$ - fração 11

Figura 22 - Distribuição dos Filos detectados no solo da amostra P04, identificados através de três bibliotecas do gene rRNA $16 \mathrm{~S}$

Figura 23 - Árvore filogenética mostrando a posição do Candidato a Filo OP10 dentre os grupos mais representativos do Domínio Bactéria. 


\section{LISTA DE ABREVIATURAS E SIGLAS}

ARMO Amazon Rainforest Microbial Observatory

$\mathrm{CO}_{2} \quad$ Dióxido de carbono

$\mathrm{CH}_{4} \quad$ Gás metano

DGGE Eletroforese em gel de gradiente desnaturante

DNA Deoxyribonucleic Acid (Ácido Desoxirribonucleico)

DNA-SIP DNA - Stable Isotope Probing - Marcação de Ácidos Nucléicos com Isótopos Estáveis

Dntp Deoxyribonucleotide Triphosphates (Desoxiribonucleotídeos Trifosfatados)

EDTA Ethylenediamine Tetraacetic Acid (Ácido Etilenodiamino Tetra-acético)

GEE Gases de efeito estufa

MMO Enzima metano mono-xigenase

NCBI National Center for Biotechnology Information

$\mathrm{N}_{2} \mathrm{O} \quad$ Óxido nitroso

PQQ Pyrroloquinolina quinona

RNA Ribonucleic Acid (Ácido Ribonucleico)

rRNA Ribosomal Ribonucleic Acid (RNA ribossomal)

TAE Tris - Acetato - EDTA 


\section{SUMÁRIO}

1 INTRODUÇÃ

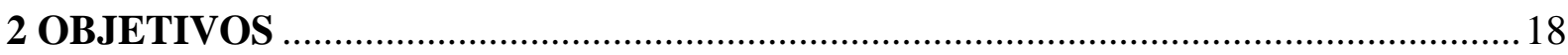

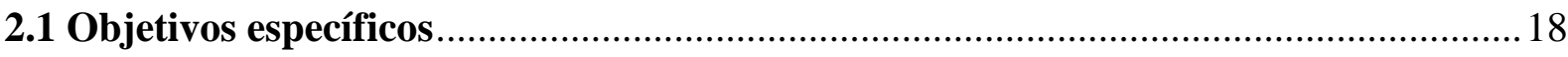

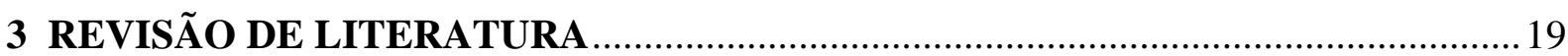

3.1 Amazônia: o desmatamento e as emissões de metano ................................................. 19

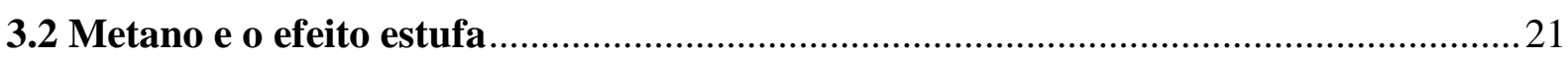

3.3 Bactérias metanotróficas e a oxidação biológica do metano (OBM) .......................... 23

3.3.1 Bactérias metanotróficas: Filogenia e taxonomia ..................................................... 24

3.3.2 Estrutura e função da Enzima metano mono -oxigenage (MMO) ...............................26

3.3.3 Bactérias metanotróficas e a diversidade de ambientes .............................................29

3.4 Métodos utilizados para o estudo das bactérias metanotróficas .................................30

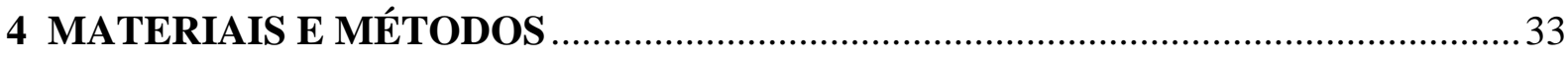

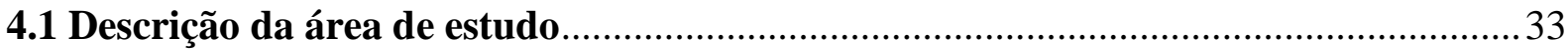

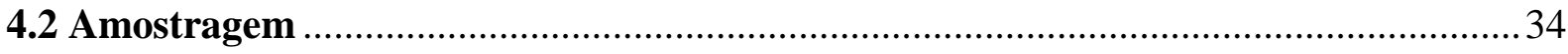

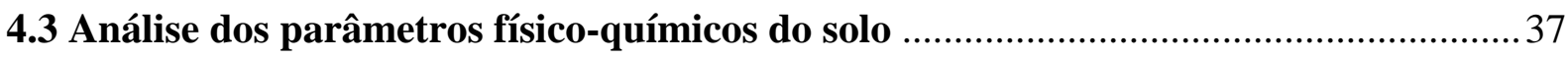

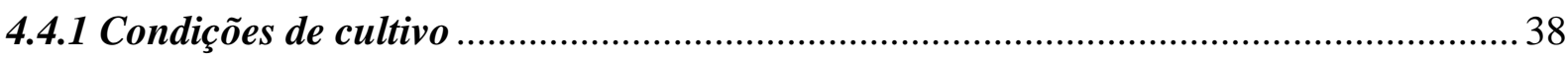

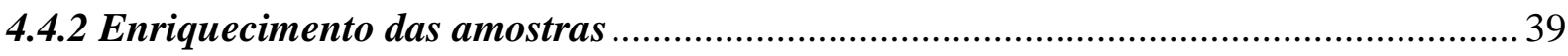

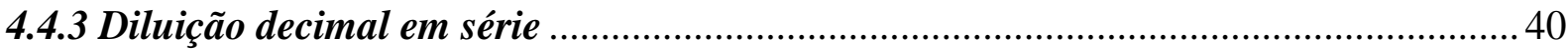

4.5 Análise da diversidade de metanotróficas em solos da Amazônia................................41

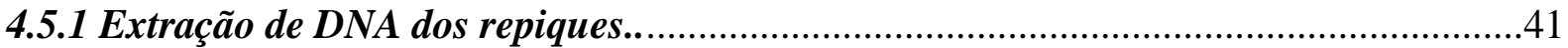

4.5.2 Detecção do gene pmoA a partir do DNA extraído dos repiques................................. 41

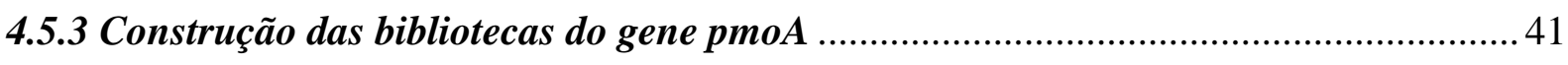

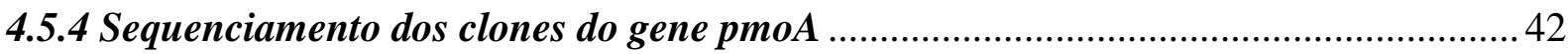

4.5.5 Análise da diversidade através das bibliotecas construídas ....................................... 42

4.5.6 Amplificação por PCR do gene rRNA 16S com primers com grampo ........................ 42

4.5.7 Eletroforese em Gel de Gradiente Desnaturante (DGGE)........................................ 43

4.6 Estudo da comunidade ativa através da aplicação da técnica de DNA-SIP .............. 43

4.6.1 Microcosmos para a aplicação da técnica de DNA-SIP ${ }^{13} \mathrm{CH}_{4}$.................................. 44

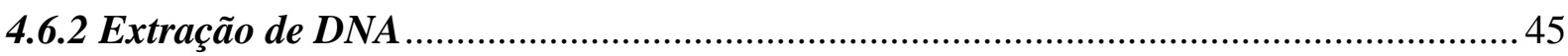

4.6.3 Fracionamento do DNA extraído dos enriquecimento s............................................. 46

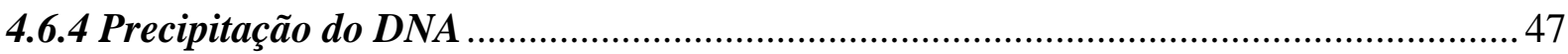


4.6.5 Amplificação por PCR gene rRNA 16S a partir do DNA obtido no DNA-SIP.

4.6.6 Construção das bibliotecas do gene rRNA $16 \mathrm{~S}$

4.6.7 Sequenciamento dos clones do gene rRNA 16S.

5 RESULTADOS E DISCUSSÃO

5.1 Influência de fatores ambientais sobre a estrutura da comunidade oxidadora de $\mathrm{CH}_{4}$

5.1.2 Correlações entre os fatores físico-químicos e a estrutura da comunidade oxidadora de $\mathrm{CH}_{4}$

5.2 Avaliação de consumo de metano

5.3 Acesso a diversidade funcional de bactérias metanotróficas, através da construção de bibliotecas do gene pmoA

5.4 Estudo da comunidade ativa para a oxidação de $\mathrm{CH}_{4}$, através do uso da técnica de Stable Isotope Probing (DNA-SIP ${ }^{13} \mathrm{CH}_{4}$ )

5.4.1 Enriquecimento

5.4.2 Resultados da ultracentrifugação e fracionamento

5.4.3 Estudos com Biologia Molecular com Material proveniente do SIP

6 CONCLUSÕES.

REFERÊECIAS . 79

APÊNDICES.

APÊNDICE A - Preparo do meio de cultura NMS 91

APÊNDICE B - Parâmetros físico-químicos 


\section{INTRODUÇÃO}

O metano é um dos principais gases que contribuem para o aquecimento do planeta, tendo uma ação 25 vezes maior do que a do $\mathrm{CO}_{2}$ em relação à retenção do calor (DALTON, 2005; INTERGOVERNAMENTAL PANEL ON CLIMATE CHANGE, 2007). O protocolo de Kyoto considera de suma importância o controle das emissões deste gás para a atmosfera, intensificando-se assim as pesquisas que visam esclarecer o papel dos micro-organismos envolvidos com o ciclo do metano em diversos ambientes.

As bactérias metanotróficas formam um grupo fisiologicamente distinto pela sua habilidade em usar o metano como única fonte de carbono e energia, desenvolvendo assim um papel importante no ciclo do metano (HANSON; HANSON, 1996). Estas bactérias possuem grande potencial na redução de emissões de $\mathrm{CH}_{4}$ para a atmosfera, pois podem formar uma espécie de barreira biológica no solo (VISVANATHAN et al., 1999), regulando o fluxo líquido de $\mathrm{CH}_{4}$ entre o solo e a atmosfera (VERCHOT et al., 2000).

Os níveis de emissões de $\mathrm{CH}_{4}$ na Amazônia estão aumentando com o passar dos anos (FEIGL et al., 2002; STEUDLER et al., 1996). Desde os anos 70, a Amazônia passa por um processo contínuo de desmatamento, sendo que, muitas destas áreas desmatadas são utilizadas na agricultura e na formação de pastagens para a pecuária (NEPSTAD et al., 2008). Muitas destas pastagens são utilizadas na criação de gado por um determinado período, sendo posteriormente abandonadas, surgindo então uma floresta secundária (FEIGL et al., 2002).

As investigações sobre a estrutura e composição das comunidades microbianas do solo da região Amazônica tem-se intensificado, assim como estudos que tentam compreender qual o impacto gerado pelas mudanças no manejo do solo para estas comunidades (JESUS et al., 2009). O entendimento de como estas comunidades microbianas respondem às perturbações ambientais é crítico para a manutenção e restauração de funções importantes do ecossistema (WU et al., 2006).

Dessa forma, buscando caracterizar a microbiota e compreender as respostas das comunidades microbianas do solo da Amazônia, frente a diferentes formas de uso, o projeto denominado - Monitoramento da Microbiota da Floresta Amazônica - (“Amazon Rainforest Microbial Observatory" - ARMO), ao qual este trabalho está integrado, reuniu pesquisadores da Universidade de São Paulo, Michigan State University, University of Massachusetts at Amherst, University of Oregon e University of Texas at Arlington.

As amostras do projeto ARMO são advindas da Fazenda Nova Vida, em Rondônia, estado este que possui uma das maiores áreas de floresta já comprometida pelo desmatamento. A 
Fazenda Nova Vida também integra um dos locais de pesquisa do LBA-ECO (Large Scale Biosphere-Atmosphere Experiment in Amazonia), sendo este um dos maiores programas de investigação internacional para estudar as consequências do desmatamento nos níveis local, regional e global.

Dentro deste contexto, o presente trabalho tem como objetivo pesquisar a diversidade taxonômica e funcional de bactérias metanotróficas a partir de amostras de uma cronossequência de solos da Amazônia, onde ocorreu a conversão de floresta à pastagem, e posteriormente à vegetação secundária, e compreender se tal manejo do solo influencia na estrutura da comunidade metanotrófica.

Para atingir os objetivos foram empregadas as técnicas clássicas de cultivo e avaliação de consumo de $\mathrm{CH}_{4}$ in vitro, além de técnicas de biologia molecular como a construção de bibliotecas do gene pmoA e a Marcação de Ácidos Nucleicos com Isótopos Estáveis" ("DNA Stable Isotope Probing” - DNA-SIP). A técnica de DNA-SIP tem se mostrado de grande importância para a microbiologia ambiental, pois possibilita estabelecer uma ligação entre filogenia e funcionalidade (CÉBRON et al., 2007 a,b). 


\section{OBJETIVOS}

Verificar a presença e a diversidade metanotrófica a partir de amostras de uma cronossequência de solos da Amazônia, onde ocorreu conversão de floresta a pastagem, e posteriormente à vegetação secundária, e verificar se tal manejo do solo influencia na estrutura da comunidade metanotrófica.

\subsection{Objetivos específicos}

a) Avaliar o consumo de metano "in vitro" a partir das amostras de solo de floresta primária, floresta secundária e de pastagem;

b) estudar a diversidade da comunidade metanotrófica enriquecida através da construção de bibliotecas do gene funcional pmoA, amplificado a partir do DNA extraído dos repiques dos cultivos das amostras de solo estudadas;

c) estudar a comunidade ativa para a oxidação de $\mathrm{CH}_{4}$, através do emprego da técnica de Stable Isotope Probing (DNA-SIP ${ }^{13} \mathrm{CH}_{4}$ ), e da construção de bibliotecas do gene rRNA 16S, construídas a partir das frações de DNA marcado e não marcado;

d) avaliar a estrutura da comunidade oxidadora de $\mathrm{CH}_{4}$ através de DGGE e correlacioná-la com as propriedades físico-químicas do solo. 


\section{REVISÃO DE LITERATURA}

\subsection{Amazônia: o desmatamento e as emissões de metano}

A Amazônia possui importante papel no ciclo global do carbono, (GALFORD et al., 2011), possuindo um significativo reservatório (FEIGL; CERRI; BERNOUX, 1998) e podendo agir também como sorvedouro de $\mathrm{CO}_{2}$ (GALFORD et al., 2011; MALHI et al., 2006; STEUDLER et al., 1996). O desmatamento e o uso do solo na região podem promover a liberação de carbono (DAVIDSON et al., 2012; FEIGL; CERRI; BERNOUX, 1998; GALFORD et al., 2011), aumentando os índices de gases de efeito estufa na atmosfera (KAUFFMAN; CUMMINGS; WARD, 1998).

A Amazônia passa por um processo de desmatamento desde os anos 70, quando grandes áreas nativas começaram a ser derrubadas (KRUSCHE et al., 2005). Até 2008 uma área com mais de 750 mil $\mathrm{Km}^{2}$ já havia sido desmatada na Amazônia Brasileira, sendo que mais de $70 \%$ desta área foi convertida a pastagem e a plantação de soja (SOARES-FILHO et al., 2006; NEPSTAD et al., 2008). Segundo o Instituto Nacional de Pesquisas Espaciais (INPE) o desmatamento após o ano de 2005 vem diminuindo, mas ainda atinge índices preocupantes, como os apresentados entre os anos de 2010 e 2011, quando chegaram a ser desmatados mais $6200 \mathrm{~km}^{2}$.

A Amazônia Brasileira compreende os estados do Acre, Amazonas, Amapá, Rondônia, Mato Grosso, Roraima, Pará, Maranhão e Tocantins. Os estados do Mato Grosso, Pará e Rondônia lideram os índices de desmatamento (Figura 1), e fazem parte do chamado "arco do desmatamento", que compreende uma região onde se encontram os maiores índices de desmatamento da Amazônia (FERREIRA; VENTICINQUE; ALMEIDA, 2005).

A formação de pastagens para pecuária é um dos principais motivos para o desmatamento (KRUSCHE et al., 2005; MALHI et al., 2006 ). Muitas destas pastagens são utilizadas na criação de gado por um determinado período, sendo após abandonadas, resultando no surgimento de floresta secundária (FERNANDES et al., 2002). O uso intensivo do solo, sem a utilização de práticas sustentáveis, leva invariavelmente a efeitos negativos ao ambiente, como a redução da matéria orgânica do solo e aumento das emissões de gases de efeito estufa (GEE) para a atmosfera (CERRI et al., 2005; FOLEY et al., 2005), além de diminuir a capacidade de captação de metano pelo solo (STEUDLER et al., 1996). 
Figura 1 - Mapa do desmatamento acumulado no bioma Amazônia até 2010.

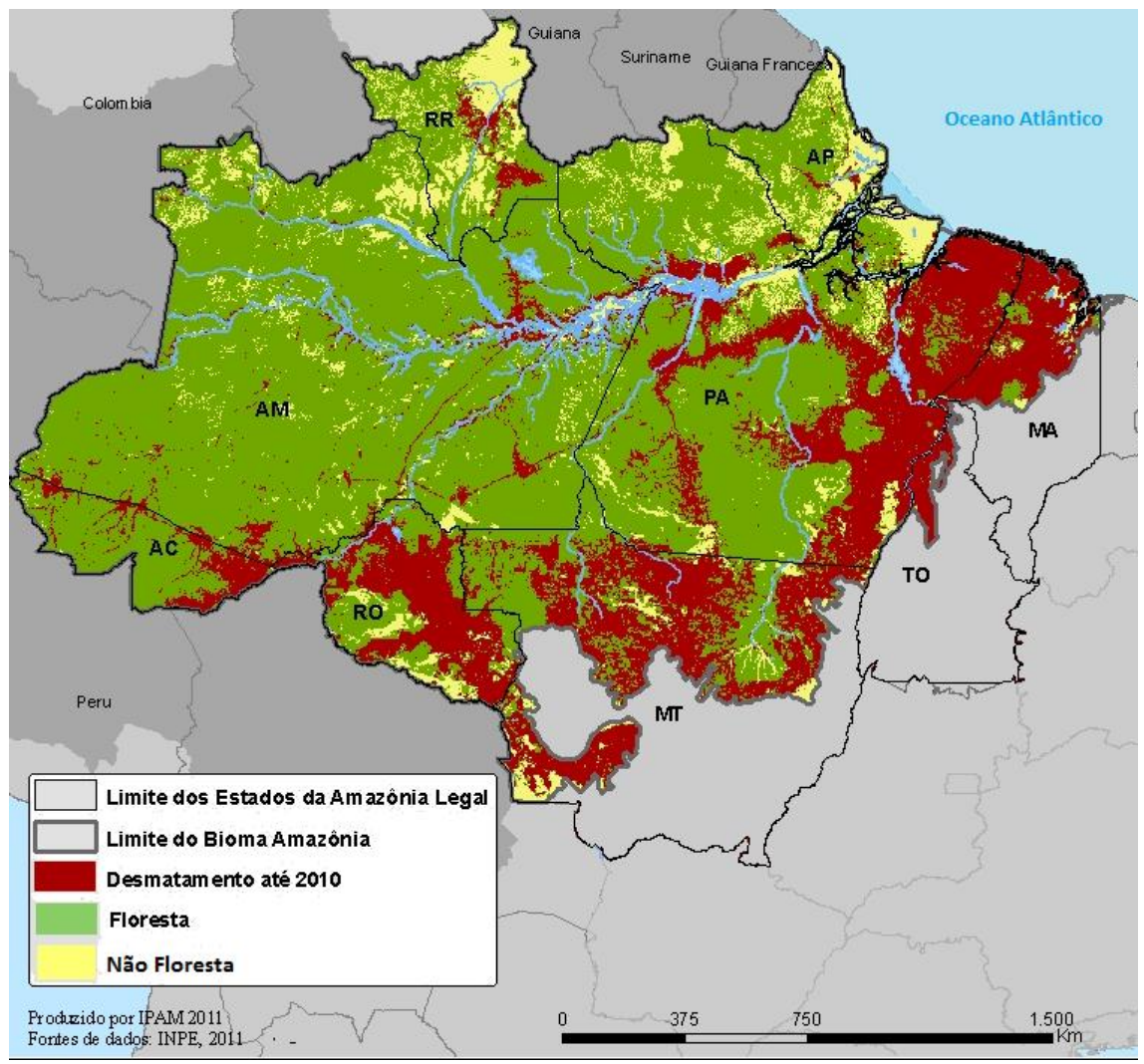

Fonte: Instituto de Pesquisa Ambiental da Amazônia (2012).

Em algumas áreas o poder dissipador e o de acumulador de $\mathrm{CH}_{4}$ podem ser o mesmo, pois, os ecossistemas terrestres servem como biofiltro do gás $\mathrm{CH}_{4}$ produzido, formando uma espécie de barreira biológica formada pelas bactérias metanotróficas, consumidoras de metano (VISVANATHAN et al., 1999). Segundo Verchot et al. (2000) as bactérias metanotróficas possuem importante papel na regulação do fluxo líquido de metano entre o solo e a atmosfera. Portanto, os impactos provocados pelas ações humanas na Amazônia podem levar a perda deste equilíbrio, e consequentemente, a maior liberação de metano para a atmosfera.

Frankenberg et al. (2005) apresentam um estudo realizado em 2003 pela Agência Espacial Européia, que indica haver um aumento nos níveis de metano atmosférico sobre a bacia Amazônica. Na Fazenda Nova Vida, em Rondônia, já foram realizados estudos que revelam haver um aumento nos níveis de emissões de $\mathrm{CH}_{4}$ associadas à conversão de floresta tropical a pastagem (FERNANDES et al., 2002), podendo com o passar dos anos após a conversão da floresta a pastagem haver um aumento gradativo nos índices de emissões de $\mathrm{CH}_{4}$ (STEUDLER et al., 1996). Outros fatores também podem estar associados ao aumento 
das emissões de metano por solos de pastagens, como a compactação do solo com tropel do gado, que acaba por diminuir a aerobicidade do solo, propiciando uma maior produção de metano por arqueias metanogênicas anaeróbias (STEUDLER et al., 1996), e uma maior retenção de água pelo solo em locais de pastagem (CERRI et al., 2005).

Existem diferenças entre comunidades microbianas presentes em solos de pastagens e de florestas (JESUS et al., 2009; NUSSLEIN; TIEDJE, 1999) e, com as alterações sofridas pelo solo estas comunidades microbianas podem ser alteradas. Estudos realizados com grupos funcionais específicos demonstraram que comunidades de arqueias oxidadoras de amônia são alteradas pelo uso do solo (TAKETANI; TSAI, 2010) e, segundo Lammel (2011), este manejo do solo pode levar a alterações na abundância de genes relacionados ao fluxo de gases do efeito estufa.

A diversidade microbiana e a diversidade funcional do solo podem servir como um indicador da qualidade do solo (PAPATHEODOROU; EFTHIMIADOU; STAMOU, 2008), e o entendimento da estrutura e composição das comunidades microbianas do solo e suas respostas às perturbações ambientais é crítico para manutenção e restauração de funções importantes do ecossistema (WU et al., 2006).

\subsection{Metano e o efeito estufa}

O efeito estufa é um problema ambiental global, definido como o aumento da retenção de calor na baixa atmosfera, devido ao aumento da concentração de certos gases naturalmente presentes na atmosfera. $\mathrm{O}$ excesso de emissões dos chamados $\mathrm{GEE}$, principalmente $\mathrm{CO}_{2}, \mathrm{CH}_{4}$ e $\mathrm{N}_{2} \mathrm{O}$, está produzindo mudanças climáticas significativas ainda em estudo (DUNFIELD et al., 2007). A redução do ritmo de produção dos GEE é a principal medida a ser tomada para combater este problema (KIPERSTOK et al., 2002).

$\mathrm{O} \mathrm{CH}_{4}$ é um dos principais gases que contribuem com o efeito estufa no planeta, tendo uma ação 25 vezes maior do que a do $\mathrm{CO}_{2}$, em relação à retenção do calor responsável pelo aquecimento do planeta (DALTON, 2005; IPCC, 2007). Alterações no clima atribuídas ao $\mathrm{CH}_{4}$ nos últimos 150 anos representam 1/3 (um terço) daquela atribuída ao $\mathrm{CO}_{2}$ (STEENBERGH et al., 2010). Hoje, estima-se que sua concentração seja em torno de 1,75 partes por milhão em volume (ppmv) (BAANI; LIESACK, 2008).

$\mathrm{O} \quad \mathrm{CH}_{4}$ é produzido em diferentes ecossistemas (Figura 2) sendo formado principalmente (80 a 90\%) pela decomposição microbiana anaeróbia da matéria orgânica e, em menor porcentagem, nos processos geotermais (MOREIRA; SIQUEIRA, 2006). Quando 
produzido nos solos, o metano formado em condições anaeróbias difunde-se para regiões aeróbias, onde parte é geralmente oxidada a dióxido de carbono pelas bactérias metanotróficas (SMITH et al., 2000) e parte segue para a atmosfera (HANSON; HANSON, 1996). Segundo Conrad (2007) as emissões de $\mathrm{CH}_{4}$ seriam consideravelmente mais elevadas sem a oxidação pelas bactérias metanotróficas, que mitigam cerca de $50 \%$ do metano produzido biogenicamente. Da quantidade liberada na atmosfera, cerca de 90\% (HANSON; HANSON, 1996) é oxidada através de reações fotoquímicas, sendo destruídos quimicamente por radicais $\mathrm{OH}^{-}$e $\mathrm{Cl}^{-}$na troposfera e estratosfera, respectivamente (CONRAD, 2007).

Figura 2 - Esquema resumido do ciclo do metano, incluindo produção e consumo.

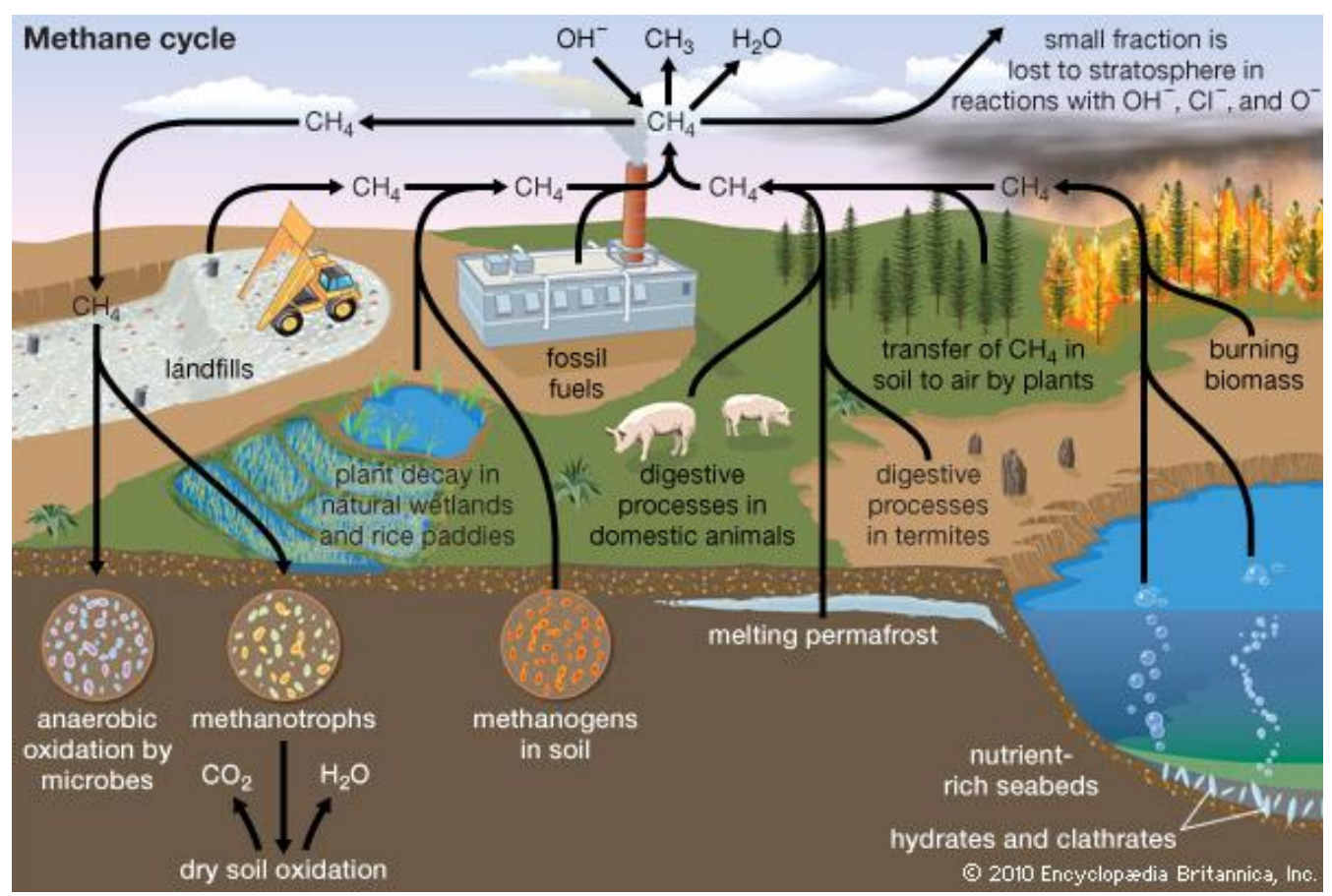

Fonte: Adaptado de Encyclopédia Britannica, 2010.

Em função das ações estabelecidas pelo protocolo de Kyoto, intensificaram-se as pesquisas voltadas para a determinação da produção de metano, do seu consumo biótico e abiótico e o controle de suas emissões. No Brasil, o Ministério das Cidades vem também incentivando Mecanismos de Desenvolvimento Limpo, de modo a possibilitar a comercialização de "créditos de carbono" aos países ou cidades que não conseguem reduzir seus níveis de emissão nos padrões exigidos pelo Protocolo de Kyoto (MALDANER, 2011). A criação do Mercado Brasileiro de Reduções de Emissões (MBRE) pelo Ministério do 
Desenvolvimento, Indústria e Comércio Exterior também mostra a preocupação com a redução das emissões de $\mathrm{CH}_{4}$ no Brasil.

Há interesse em estimar o potencial emissor ou sorvedor de metano do solo, em diversos ambientes, como na Península Antártica (NAKAYAMA et al., 2011) áreas de solo alagadas como os manguezais (LINHARES, 2011), aterros sanitários (MALDANER, 2011; TORVES, 2008), florestas tropicais (DO CARMO et al., 2006; KOLB, 2009) pastagens (FERNANDES et al., 2002; STEUDLER et al., 1996) e áreas de reflorestamento (SINGH et al., 2009) entre outros. Este tipo de monitoramento ainda não é feito de forma sistemática, embora seja importante para estimar os impactos que mudanças no uso destes ambientes podem provocar, do ponto de vista do equilíbrio gasoso entre a superfície e a atmosfera.

\subsection{Bactérias metanotróficas e a oxidação biológica do metano (OBM)}

As bactérias metanotróficas formam um grupo fisiologicamente único e distinto pela sua habilidade em usar o metano como única fonte de carbono e energia (HANSON; HANSON, 1996; MURRELL; MACDONALD; BOURNE, 1998; WISE; MCARTHUR; SHIMKETS, 1999), sendo em sua maioria aeróbicas, embora existam na forma anaeróbica (DALTON, 2005). Este fenômeno ocorre na presença de $\mathrm{CH}_{4}$ e oxigênio (mesmo em baixas concentrações) (BARLAZ et al., 2004; BOECKX; VAN CLEEMPUT; VILLARALVO, 1996; BORJESSON et al., 1997; EINOLA; KARHU; RINTALA, 2008). O $\mathrm{CH}_{4}$ é, em geral, oxidado a $\mathrm{CO}_{2}$, porém alguns estudos vêm pontuando que uma grande porção deste gás é consumida no processo de oxidação sem produzir o dióxido de carbono (BORJESSON; CHANTON; SVENSSON, 2001). A reação a seguir é a comumente descrita para a utilização aeróbia do metano:

$$
\mathrm{CH}_{4}+2 \mathrm{O}_{2}=\mathrm{CO}_{2}+2 \mathrm{H}_{2} \mathrm{O} \quad \Delta \mathrm{G}^{\mathrm{o}}=-778 \mathrm{~kJ} / \mathrm{mol}
$$

A maioria das linhagens de bactérias metanotróficas descritas até o momento pertence ao Filo Proteobacteria e estão classificadas como um subgrupo funcional de bactérias metilotróficas (HANSON; HANSON, 1996). As metilotróficas são capazes de crescer utilizando compostos $\mathrm{C} 1$, tais como metanol e metilamina, como também uma variedade de compostos C2, C3 e C4, sendo assim, obrigatórias ou facultativas, respectivamente (HANSON; HANSON, 1996; LIDSTROM, 1990; LIDSTROM, 2006). 


\subsubsection{Bactérias metanotróficas: Filogenia e taxonomia}

A divisão Proteobacteria apresenta bactérias Gram-negativas, com grande diversidade de formas e metabolismos. A diversidade de estudos e hipóteses sobre a diferenciação ecológica dos dois tipos de metanotróficas do Filo Proteobacteria, ainda se apresenta bastante incompleto se comparado com outros grupos funcionais (HOLMES et al., 1999). Os gêneros de metanotróficas conhecidos e pertencentes a este Filo estão divididos em dois tipos: tipo I, pertencentes à subdivisão Gammaproteobacteria, e tipo II, pertencentes à subdivisão Alphaproteobacteria (HANSON; HANSON, 1996; SEMRAU; DISPIRITO; YOON, 2010).

Os dois tipos de bactérias metanotróficas se distinguem pela existência e tipos de complexos membranosos, pela composição dos fosfolipídios predominantes na membrana, pela forma de metabolizar o formaldeído (DEDYSH et al., 2007), além da habilidade de fixar nitrogênio, formação de esporos ou cistos e conteúdo G+C (DALTON, 2005).

As metanotróficas do tipo I apresentam ácidos graxos de 16 carbonos nas membranas, e estas se encontram organizadas como feixes de vesículas discóides distribuídas por toda a célula. Esse grupo corresponde à família Methylococcaceae, na qual se encontram os gêneros: Methylococcus sp., Methylomonas sp., Methylobacter sp., Methylomicrobium sp., Methylosphaera sp., Methylocaldum sp., Methylosarcina sp., Methylossoma sp., estas assimilam o formaldeído produzido na oxidação do metano (via metanol) utilizando a rota da monofosfato ribulose. Novos gêneros pertencentes à subdivisão Gammaproteobacteria foram incluídos ao grupo: Methylohalobius, Methtyhlothermus (KALYUZHNAYA et al., 2005; RAHALKAR et al., 2007; SEMRAU; DISPIRITO; YOON, 2010).

As metanotróficas pertencentes ao tipo II utilizam a rota da serina para a assimilação do formaldeído, apresentam nas membranas predominantemente ácidos graxos de 18 carbonos e estas se encontram emparelhadas ao longo da periferia celular, pertencem a família Methylocystaceae, e incluem os gêneros Methylosinus sp. e Methylocystis sp. (HANSON; HANSON, 1996) e Methylocella sp. e Methylocapsa sp. (DEDYSH, 2000; DUNFIELD et al., 2003; SEMRAU; DISPIRITO; YOON, 2010).

Algumas exceções já são conhecidas, como: a espécie Methylocystis heyeri que pertecente ao gênero Methylocystis, e contém ácidos graxos de 16 carbonos em sua membrana, diferentemente das demais metanotróficas do tipo II, que contém acidos graxos de 18 carbonos em sua membrana. (DEDYSH et al., 2007). Outra exceção ocorre com as metanotróficas pertencente ao gênero de Methylocella sp. que diferem das outras metanotróficas pela sua capacidade de consumir compostos com mais de um carbono, como 
piruvato, succinato, malato, etanol e acetato, sendo este último consumido preferencialmente em relação ao metano quando ambos estão disponíveis (DEDYSH; KNIEF; DUNFIELD, 2005). O micro-organismo Methylothermus thermalis, que validou o gênero Methylothermus, apresenta ácidos graxos com 16 e 18 carbonos em sua membrana (TSUBOTA, 2005).

Novos grupos de bactérias metanotróficas têm sido descobertos recentemente. Entre as novas descobertas estão as espécies Crenothrix polyspora e Clonothrix fusca, duas bactérias filamentosas, que apesar de terem sido descobertas a mais de 100 anos, somente há poucos anos foram reconhecidas como capazes de oxidar metano (SEMRAU; DISPIRITO; YOON, 2010; STOECKER et al., 2006; VIGLIOTTA et al., 2007). Estas estão sendo agrupadas a bactérias metanotróficas do tipo I, pertencente à família Methylococcaceae (OP DEN CAMP et al., 2009; VIGLIOTTA et al., 2007).

Novas linhagens acidófilas pertencentes à Divisão Verrucomicrobia, também têm sido apresentadas, porém pouco se sabe sobre as metanotróficas pertencentes á esta Divisão (DUNFIELD et al., 2007; ISLAM et al., 2008; POL et al., 2007). As três cepas de metanotróficas Verrucomicrobia relatadas até o momento são termófilas, apresentam um crescimento ótimo em temperaturas que variam entre $55^{\circ} \mathrm{C}$ e 65 , e foram incluídas ao gênero Methylacidiphulum (SEMRAU; DISPIRITO; YOON, 2010).

Existem algumas hipóteses descritas que podem explicar as diferenças ecológicas entre metanotróficas do tipo I e do tipo II, mas ainda não há uma ampla compreensão de como os gêneros diferem ecologicamente. Acredita-se que existem fatores que influenciam sua distribuição e competição, como as concentrações de acetato, $\mathrm{CH}_{4}$, oxigênio, disponibilidade de nitrogênio e cobre, pH e temperatura (MOHANTY et al., 2007), além da presença de inibidores (KIGHTLE; NEDWELL; COOPER, 1995; VISVANATHAN et al., 1999). A capacidade de fixar $\mathrm{N}_{2}$ pode ser também um fator de competição importante nos ambientes pobres em formas facilmente assimiláveis deste nutriente, visto que poucos gêneros de metanotróficas do tipo I (Methylococcus sp. e Methylosphaera sp.) apresentam esta habilidade, enquanto todos os gêneros pertencentes ao tipo II a possuem (LIOTTI, 2007).

Bactérias metanotróficas do tipo I têm sido associadas ao grupo que possui alta afinidade por metano, sendo capazes de oxidar metano em concentrações atmosféricas, enquanto metanotróficas do tipo II são associadas ao grupo de baixa afinidade (EINOLA; KETTUNEN; RINTALA, 2007; SINGH et al., 2007). Bender e Conrad (1994) já sugeriam a existência de duas populações diferentes de metanotróficas em solos expostos a diferentes concentrações de metano, uma apresentando uma enzima metano mono-oxigenage (MMO) de alta afinidade, e outra de baixa afinidade ao gás. 
Esta hipótese sobre afinidades diferentes ao $\mathrm{CH}_{4}$ tem sido estudada ao longo dos anos. Estudo realizado por Knief e Dunfield (2005), apresenta resultados que invertem esta tendência na presença de índices de metano inferiores a 1000 ppmv, sugerindo que metanotróficas do tipo II se tornam mais oligotróficas, ou seja, mais competitivas que as do tipo I diante destas condições.

Outro estudo realizado foi conduzido por Baani e Liesack (2008), no qual foi detectada a ocorrência de duas isozimas da forma particulada da enzima MMO em linhagem do gênero Methylocystis sp., revela que a isozima pMMO2 é expressa constitutivamente em metanotróficas do tipo II e é capaz de oxidar metano até mesmo em concentrações traço, enquanto a forma pMMO1 oxida metano apenas em concentrações maiores que 600 ppm.

Nota-se que há uma grande diversidade de estudos e hipóteses sobre a diferenciação ecológica dos dois tipos de metanotróficas, com resultados nem sempre convergentes. Assim percebe-se que ainda existe muito a ser esclarecido, e que o equilíbrio competitivo entre metanotróficas do tipo I e tipo II não apresenta um padrão único que possa ser postulado.

\subsubsection{Estrutura e função da enzima metano mono-oxigenage (MMO)}

A enzima que catalisa a oxidação do metano a metanol é a metano mono-oxigenase MMO (DEDYSH et al., 2000; HANSON; HANSON, 1996). A enzima utiliza o $\mathrm{O}_{2}$ incorporando um átomo de oxigênio ao substrato formando metanol $\left(\mathrm{CH}_{3} \mathrm{OH}\right)$, com o outro átomo há formação de $\mathrm{H}_{2} \mathrm{O}$. Na reação seguinte, a enzima metanol desidrogenase (MDH), que funciona com a PQQ (pyrroloquinolina quinona) como aceptor de elétrons, catalisa a oxidação do metanol a formaldeído, forma pela qual o carbono é assimilado para formar intermediários das rotas metabólicas centrais, que serão subsequentemente usadas para biossíntese de material celular (DUNFIELD et al., 2002).

São conhecidas duas formas da enzima MMO; uma forma particulada (pMMO), presente na membrana celular de todas as metanotróficas, com exceção do gênero Methylocella sp. (DEDYSH et al., 2000); e uma forma solúvel citoplasmática (sMMO), encontrada apenas em algumas espécies. A assimilação do formaldeído pode ocorrer pela Via Ribulose Monofosfato (RuMP) nas metanotróficas do tipo I, ou pela Via da Serina, nas metanotróficas do tipo II (HANSON; HANSON, 1996). Um esquema geral das etapas bioquímicas da oxidação do metano encontra-se apresentado na Figura 3. 
Figura 3 - Esquema do metabolismo da oxidação biológica do metano

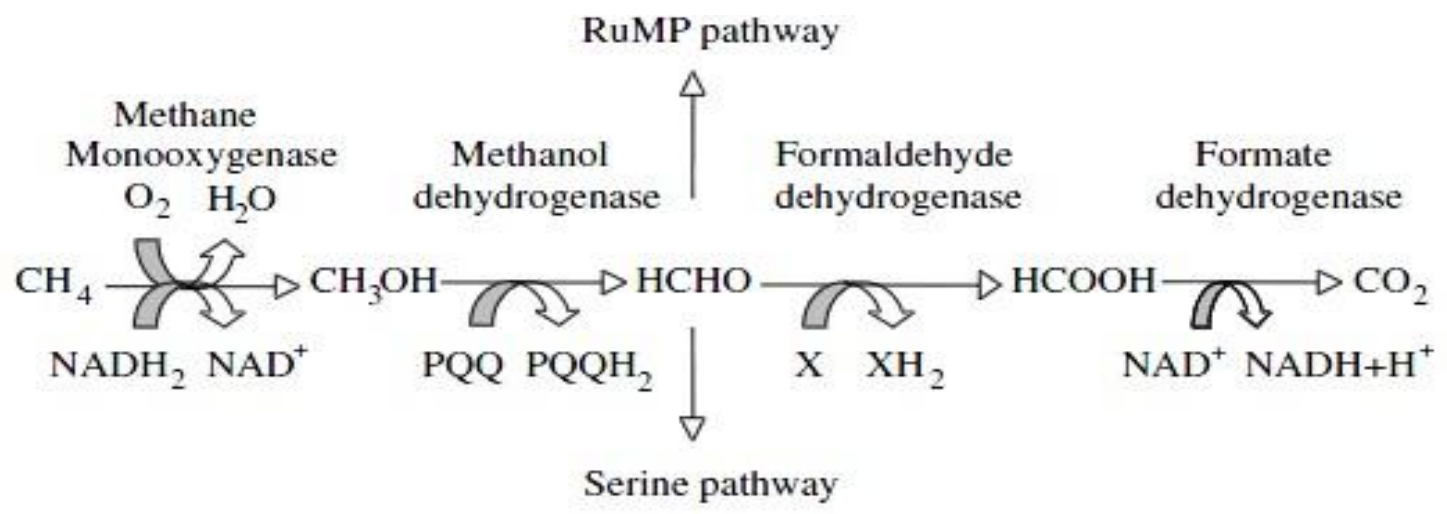

Fonte: MCDonald, Radajewski e Murrell, 2005

A forma citoplasmática (sMMO) contém três componentes: uma hidroxilase , que abriga o sítio ativo, uma redutase, que transfere elétrons de NADH para o sítio ativo, e uma proteína regulatória ou unidade $\beta$. Embora o local ativo e químico da enzima sMMO esteja bem estabelecido, a natureza do centro catalítico do pMMO continua controverso, principalmente quanto à quantidade e tipos de íons metálicos presentes (HAKEMIAN et al., 2008; SMITH et al., 2008). De uma forma geral, a estrutura da enzima pMMO é composta por três cópias de cada uma de suas três subunidades: $\alpha(p m o B), \beta(p m o A)$ e $\gamma(p m o C)$, (Figura 4) arranjadas na forma $\alpha 3 \beta 3 \gamma 3$ (HAKEMIAN; ROSENZWEIG, 2007).

Os genes que codificam para essa enzima encontram-se agrupados em um operon, na ordem $p m o C$ (subunidade $\gamma$ ), pmoA (subunidade $\beta$ ) e $p m o B$ (subunidade $\alpha$ ) (MURRELL; RADAJEWSK, 2000; SEMRAU; DISPIRITO; YOON, 2010). A localização do sítio ativo da enzima ficou indeterminada por muito tempo, mas já se acreditava que estaria na subunidade $\beta$ (pmoB), codificada pelo gene pmoA. Mais tarde, a descoberta da estrutura cristalográfica de pMMO levantou a possibilidade de que o sítio ativo poderia estar localizado em algum dos centros ligantes de metais (LIEBERMAN; ROSENZWEIG, 2005). Balasubramanian et al. (2010) aprofundaram os estudos na estrutura de pMMO de $M$. capsulatus e demonstraram que o sítio ativo está localizado na região N-terminal do domínio solúvel do peptídeo pmoB, onde se encontra o centro dinuclear de ligação de cobre $(\mathrm{Cu})$.

Possivelmente por abrigar a codificação para o sítio ativo da enzima, o gene pmoA possui uma sequência muito conservada e sua presença é quase universal no genoma das 
metanotróficas conhecidas (HOLMES et al., 1995; MURRELL; RADAJEWSK, 2000; RASTOGI et al., 2009; SEMRAU; DISPIRITO; YOON, 2010). Estas particularidades tornaram viável a ampla utilização deste gene como marcador filogenético para identificar e classificar especificamente as bactérias metanotróficas.

A concentração de cobre $(\mathrm{Cu})$ tem importante papel na regulação da expressão da enzima MMO (DALTON, 2005), podendo agir como inibidor quando presente em altas taxas, ou em baixa concentração. Em metanotróficas que expressam pMMO o $\mathrm{Cu}$ pode alterar a afinidade e especificidade ao substrato (SEMRAU; DISPIRITO; YOON, 2010). Em metanotróficas que expressam ambas as formas de MMO, a forma sMMO somente é expressa em condições com concentração de cobre $(\mathrm{Cu})$ abaixo de $0,8 \mu \mathrm{M}$, enquanto a pMMO é largamente expressada em meio com concentração de cobre em torno de $4 \mu \mathrm{M}$ (HAKEMIAN; ROSENZWEIG, 2007).

A ação da enzima MMO pode ser inibida na presença de amônia $\left(\mathrm{NH}_{3}\right)$, agindo principalmente sobre a sMMO, pois favorece bactérias nitrificantes. O mecanismo para inibição na oxidação do metano por amônia não é completamente entendido, mas o efeito depende da concentração de amônia no meio (DUNFIELD et al., 2002). 
Figura 4 - Estruturas de Methylocystis sp. apresentando as subunidades de pMMO

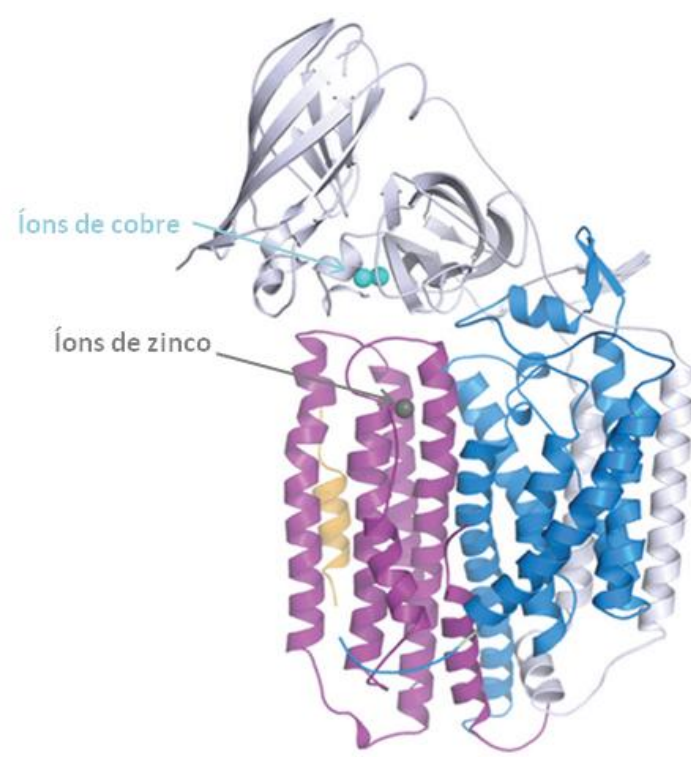

Estruturas de Methylocystis sp. apresentando as subunidades de pMMO sendo $p m o B$ em cinza, $p m o A$ em azul e pmoC em roxo.

Fonte: Adaptado de Smith et al., 2011.

\subsubsection{Bactérias metanotróficas e a diversidade de ambientes}

Organismos metanotróficos estão presentes em diversos ambientes, como nos solos alagados, cobertura de aterros sanitários, solo de florestas decíduas, coluna d'água, sedimento de lagos e rios, lodos de esgoto, plantações de arroz, turfeiras, tundra antártica e lagos alcalinos (BOWMAN, 2006; HANSON; HANSON, 1996; KNIEF; LIPSKI; DUNFIELD, 2003; MURRELL; MACDONALD; BOURNE, 1998; WISE; MCARTHUR; SHIMKETS, 1999). Além disso, cada vez mais surgem registros de endossimbiose com mexilhões, esponjas (DUBILIER; BERGIN; LOTT, 2008), e em associação com plantas típicas de ambientes alagados (RAGHOEBARSING et al., 2005).

Os primeiros trabalhos que caracterizaram a distribuição de bactérias metanotróficas sugeriam que estas eram em sua maioria neutrófilas e mesófilas, ou seja, tendo seu crescimento ótimo em $\mathrm{pH}$ neutro e temperatura moderada $\left(25^{\circ} \mathrm{C}\right)$ (SEMRAU; DISPIRITO; YOON, 2010). Recentemente novos estudos revelam a existência de metanotróficas vivendo 
em condições mais extremas. Já foram descritas metanotróficas conhecidas como termofílicas e termotolerantes, psicrófilas e psicotolerantes, halotolerantes, além de metanotróficas acidófilas e alcalinotolerantes (SEMRAU; DISPIRITO; YOON, 2010).

As espécies Methylocaldum tepidium e Methylocaldum gracile são representantes do grupo das termotolerantes, pois crescem sob temperatura de até $47{ }^{\circ} \mathrm{C}$, já as bactérias pertecentes a espécie Methylocaldum szegendiense são um bom exemplo de metanotróficas termofílicas, podendo crescer a uma temperatura de até $62^{\circ} \mathrm{C}$ (BODROSSY et al., 1997).

Estudos recentes informam que apenas três espécies de metanotróficas psicrófilas foram isoladas, estas tem crescimento ótimo em temperatura de até $15{ }^{\circ} \mathrm{C}$. A primeira espécie descrita foi a Methylobacter psychrophilus, que foi isolada a partir de solo de tundra da Rússia (TOUROVA et al., 1999). As bactérias pertecentes ao grupo das halofílicas podem crescer em concentrações de sal de até 43\%, como a espécie Methylohalobius crimeensis, que foi isolada de lagos hipersalinos da Ucrânia (HEYER et al., 2005).

Alguns exemplares de metanotróficas acidófilas foram descritas por Dedysh et al. $(1998,2000)$ e, apresentavam maior consumo de metano em pH baixo, entre 4,5 e 5,5. Mais recentemente foi descrita a primeira metanotrófica alcalinotolerante, esta teve seu o primeiro isolado a partir de lagos da Sibéria, que chegavam a apresentar pH de 9,7 (ESHINIMAEV; KHMELENINA; TROTSENKO, 2008).

\subsection{Métodos utilizados para o estudo das bactérias metanotróficas}

Vários métodos são propostos para estudos que envolvem a ecologia microbiana do solo. A diversidade biológica é geralmente utilizada como índice que reflete a qualidade do ecossistema, de modo que as metodologias que possibilitam o estudo da diversidade microbiana também podem indicar diferenças entre solos, suas populações e suas funções (YIN et al., 2000).

A utilização de técnicas moleculares se fez importante diante das limitações das técnicas clássicas (DUARTE, 2010), pois oferecem maior sensibilidade e especificidade, que as técnicas convencionais. O desenvolvimento destas técnicas possibilitou o acesso à diversidade microbiana do solo, revelando que esta é extremamente maior do que pode ser avaliado por técnicas de cultivo (HE et al., 2008).

Os estudos da diversidade e estrutura das comunidades, avaliando marcadores filogenéticos, como o gene 16S rRNA, se fazem muito importantes, devido a características como ubiquidade e propriedades evolucionárias desse gene (DUARTE, 2010). Uma 
particularidade do gene rRNA $16 \mathrm{~S}$ é a presença de regiões altamente conservadas, as quais permitem o desenho de primers específicos, e regiões hipervariadas, as quais são utilizadas para inferir relações filogenéticas entre os micro-organismos (WARD et al., 1990).

O estudo da comunidade funcional se faz também necessário, devido à importância de se inferir não apenas a distribuição de espécies de bactérias, mas também a sua capacidade metabólica (YIN et al., 2000), ou seja, as funções que podem ser realizadas pelos microorganismos presentes (HE et al., 2011). Um grande número de métodos com diferentes abordagens e poder de resolução, já foram desenvolvidos para estudar genes funcionais em amostras ambientais (PAULA, 2012).

Para o estudo de bactérias metanotróficas, além dos procedimentos clássicos, também são adotadas as técnicas de biologia molecular. Para avaliar a diversidade do gene no ambiente, é possível construir bibliotecas gênicas a partir da clonagem dos genes funcionais, como o pmoA, que está presente em todas as bactérias metanotróficas, com exceção de Methylocella sp (DEDYSH et al., 2000).

O princípio da técnica de clonagem baseia-se na inserção de um segmento de DNA de interesse em um vetor, o qual é introduzido em uma célula hospedeira. Células de E. coli são frequentemente usadas pois são de fácil propagação e manutenção. A partir do crescimento de colônias das bactérias que receberam o vetor, procede-se a amplificação do fragmento clonado através de reação em cadeia da polimerase (PCR). De forma geral, os produtos desta PCR representam os genes das populações dominantes na comunidade estudada, e o sequenciamento destes fragmentos permite a identificação das sequências em bancos de dados como o GenBank, além da construção de filogenias.

A técnica de DGGE (Eletroforese em Gel de Gradiente Desnaturante) é outra ferramenta molecular bem estabelecida na microbiologia ambiental, e permite o estudo do comportamento e da complexidade de comunidades microbianas. Ela separa fragmentos de DNA de acordo com características de sua sequência, sendo eficiente para mostrar variabilidade dentro da comunidade e fazer comparações entre amostras (THIES, 2007). Outro ponto positivo dessa técnica é que permite a identificação de membros da comunidade por sequenciamento das bandas obtidas do gel ou por análise de hibridização com sondas especificas (MUYZER; SMALLA, 1999).

Para a aplicação desta técnica, fragmentos dos genes de interesse são amplificados por PCR com a utilização de primers com grampo, que consiste em uma extensão de cerca de 40 nucleotídeos ricos em Guanina e Citosina, que ajudam a dar estabilidade ao fragmento durante a migração no DGGE. Os produtos desta PCR são então aplicados em um gel de 
poliacrilamida. A separação ocorre à medida que os fragmentos de DNA migram no gel poliacrilamida contendo agentes desnaturantes, como a uréia e a formamida. Durante a eletroforese, os fragmentos de DNA migram com velocidades diferentes, decorrentes de sua desnaturação, específica para cada sequência de nucleotídeos, o que permite a separação das moléculas segundo a sua composição (MUYZER; DE WAAL; UITTERLINDEN, 1993; MUYZER; SAMALA 1999).

Desenvolvida mais recentemente a técnica de marcação com isótopo estável - SIP (Stable Isotope Probing), tem se sido bem sucedida na identificação de micro-organismos ativos que assimilam carbono, além de atuar como uma ferramenta importante para atribuir funções metabólicas para diversos organismos que habitam uma variedade de ambientes terrestres e aquáticos (DUNFORD; NEUFELD, 2010). Esta técnica tem como princípio a exposição de uma amostra ambiental contendo um substrato com carbono ou nitrogênio, enriquecidos com isótopos estáveis $\left({ }^{13} \mathrm{C}\right.$ ou $\left.{ }^{15} \mathrm{~N}\right)$ de baixa abundância natural, que são assimilados na biomassa da comunidade microbiana ativa, incluindo a incorporação nos ácidos nucléicos (BOSCHKER; MIDDELBURG, 2002).

Após a incubação da amostra com o composto marcado, extrai-se o DNA, que é submetido a ultracentrifugação por gradiente de densidade para separar ácidos nucleicos de densidades diferentes. Após o fracionamento, cada fração irá conter o genoma completo de toda uma população microbiana que é capaz de incorporar o substrato em seu ácido nucléico. O DNA recuperado marcado (DNA pesado) e não marcado (DNA leve), é utilizado para a caracterização molecular subsequente, por exemplo, bibliotecas gênicas, DGGE, etc (DUNFORD; NEUFELD, 2010; MURELL et al., 2010; NEUFELD et al., 2007).

O desenvolvimento de novas técnicas de biologia molecular como PCR em tempo real (TAKETANI et al., 2009), Microarray (WU et al., 2006) e o Pirosequenciamento (ROESCH et al., 2007; TEIXEIRA et al., 2010), juntamente com os avanços na bioinformática, tem oferecido novas possibilidades para os estudos em ecologia microbiana, permitindo a identificação e compreensão dos mecanismos moleculares, além de estudar a distribuição e dispersão de diferentes genes em comunidades naturais ou alteradas (LEE et al., 2011; SANTOS et al., 2011). 


\section{MATERIAIS E MÉTODOS}

\subsection{Descrição da área de estudo}

Os estudos foram realizados com amostras de solo coletadas na Fazenda Nova Vida (62 49' 27” $\left.\mathrm{W} ; 10^{\circ} 10^{\prime} 5^{\prime \prime} \mathrm{S}\right)$, que compreende uma área de 22 mil hectares no município de Ariquemes - RO, a $250 \mathrm{~km}$ ao sul da cidade de Porto Velho (Figura 5). Segundo a classificação climática de Köppen o clima predominante é do tipo Aw - tropical úmido chuvoso, com precipitação média anual $2200 \mathrm{~mm}$ e temperatura média de $25{ }^{\circ} \mathrm{C}$ (BASTOS ; DINIZ, 2004), a umidade do ar é cerca de 85\% (MORTATTI et al., 1989; RÔNDONIA 2003). O solo predominante é o Argissolo, e a vegetação é classificada como floresta tropical úmida (RÔNDONIA, 2003).

A principal atividade da fazenda é a criação extensiva de gado. De um modo geral, a implantação das pastagens é feita com pouca tecnologia e sem aplicação de fertilizantes químicos ou práticas agrícolas mecanizadas. O plantio das gramíneas Brachiaria brizantha e Panicum maximum, é realizado após ocorrer o corte e queima da vegetação. As ervas daninhas são controladas periodicamente com fogo e quando as pastagens são consideradas improdutivas, são abandonadas, dando origem a uma floresta secundária.

A Fazenda Nova Vida retrata bem o sistema de uso do solo no estado de Rondônia, onde são encontrados mosaicos com remanescentes de floresta primária, intercaladas por pastagens criadas em diferentes anos e florestas secundárias em diferentes estágios de recuperação. A Fazenda Nova Vida também faz parte do Programa de Grande Escala da Biosfera-Atmosfera da Amazônia ("Large Scale Bioshpere-Atmosphere Experiment in Amazon - LBA; www.lbaeco.org/lbaeco).

Os impactos que o desmatamento e o manejo do solo geram sobre o ecossistema, são fortemente estudados neste local da Amazônia. Estudos de monitoramento de fluxos de gases do efeito estufa e emissões de $\mathrm{CH}_{4}$ já foram realizados nesta área (CERRI et al., 2003; NEILL et al., 2005; STEUDLER et al., 1996), porém a diversidade de bactérias metanotróficas, somente agora começa a ser estudada. 
Figura 5 - $\quad$ Mapa com a localização da Fazenda Nova.

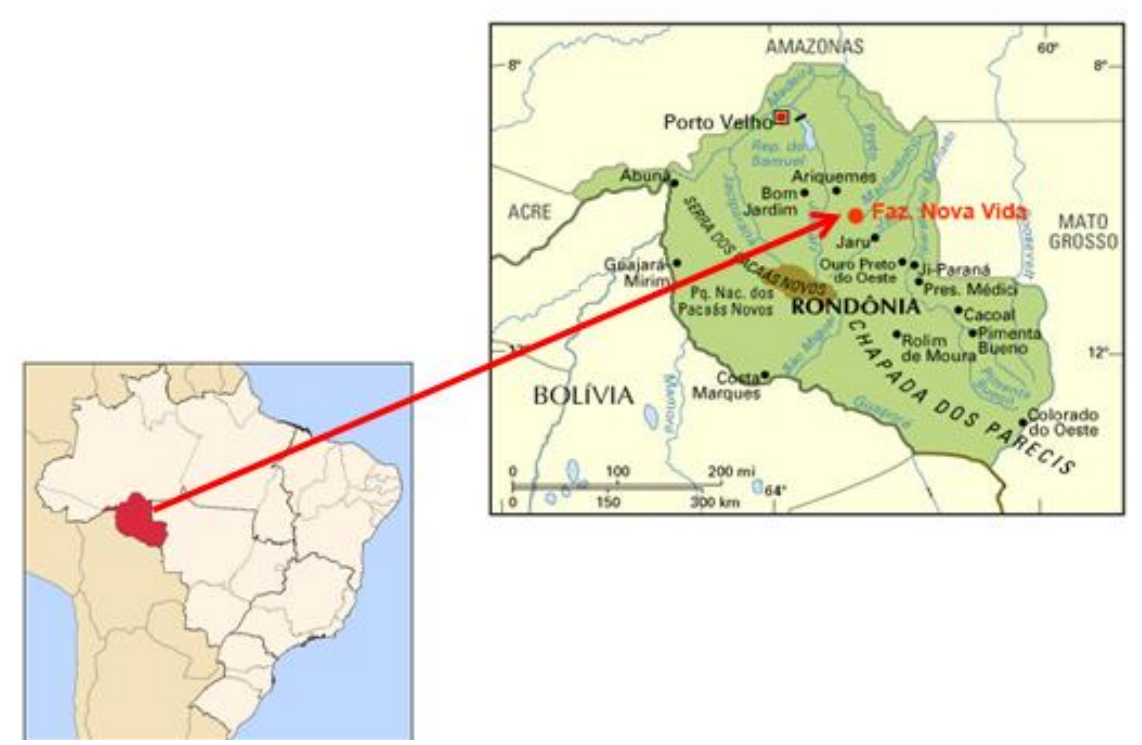

A seta na figura da ampliação do estado de Rondônia, à direita.

Fonte: Tessaro (2012).

\subsection{Amostragem}

A coleta foi realizada no mês de março do ano de 2010. Os sítios de amostragem selecionados foram: uma floresta primária, considerada área preservada; três pastagens estabelecidas em diferentes anos, 1911 (antiga), 1972 (em estabilização) e 2004 (recente), sendo ainda na data da coleta utilizadas como pastagem; e uma floresta secundária, que foi usada como pastagem até 1997, quando foi abandonada e tomada por vegetação secundária, que vem se estabelecendo desde então (Figura 6). Todos os sítios eram caracterizados como floresta tropical úmida anteriormente à intervenção antrópica. 
Figura 6 - Esquema da cronossêquencia do solo amostrado.
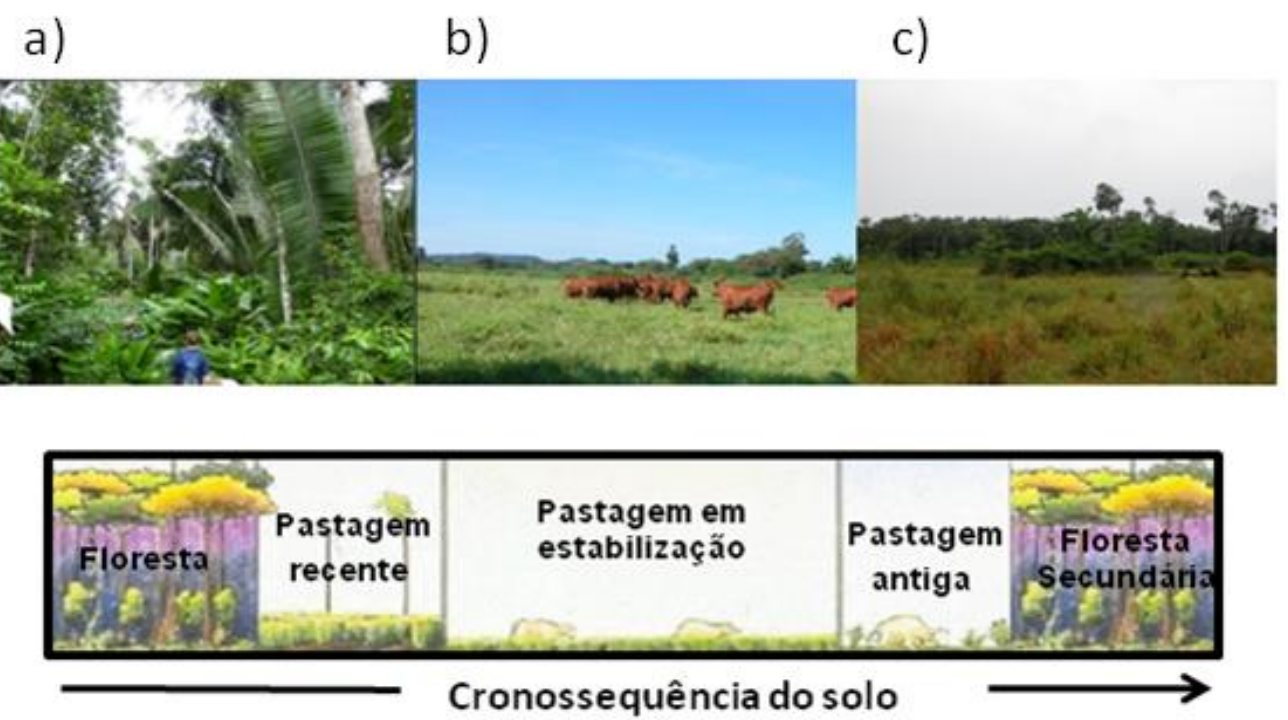

A Figura 4a representa floresta primária, $4 \mathrm{~b}$ pastagens e a Figura $4 \mathrm{c}$ representa floresta secundária.

Fonte: Tessaro (2012)

Em cada um dos cinco sítios foi utilizado um sistema de amostragem em escala espacial (desenhado pelo Prof. Dr. Brendan Bohannan, da "University of Oregon"), no qual foi feito um quadrante de $100 \mathrm{~m}^{2}$, composto de 12 (doze) pontos de coleta. Dos pontos coletados, apenas três pontos foram selecionados para serem utilizados neste trabalho. Foram coletadas três amostras compostas para cada sítio estudado, sendo que a distância de coleta entre as amostras utilizadas foi de $1 \mathrm{~m}, 10 \mathrm{~m}$ e $100 \mathrm{~m}$. As coletas de solo foram realizadas utilizando cilindros de tamanhos padronizados, atingindo uma profundidade de 0 a $10 \mathrm{~cm}$. Na Figura 7 é apresentada uma imagem de satélite dos sítios amostrados. 
Figura 7 - Imagem de satélite da Fazenda Nova Vida, com a localização dos cinco sítios de amostragem.

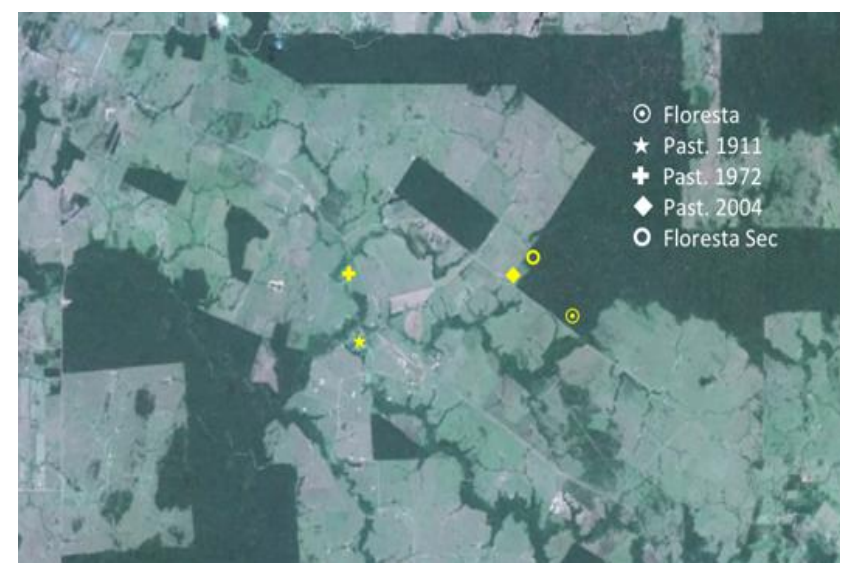

Fonte: Google Earth, adaptado e cedido gentilmente por Fabiana Paula (2012).

Após a coleta, as amostras foram acondicionadas à temperatura de $4{ }^{\circ} \mathrm{C}$ e transportadas até o local de processamento (Rondônia), onde parte da amostra foi peneirada $(2 \mathrm{~mm})$ e congelada $\left(-20{ }^{\circ} \mathrm{C}\right)$ para a posterior realização dos procedimentos de extração de DNA em laboratório. Outra parte foi mantida sob refrigeração a $4{ }^{\circ} \mathrm{C}$ para posteriores análises físicoquímicas e cultivo. A Figura 8 apresenta um esquema das etapas de trabalho realizadas a partir da coleta realizada no ano de 2010. 
Figura 8 - Fluxograma da metodologia empregada para o estudo da comunidade metanotrófica em solos da Amazônia.

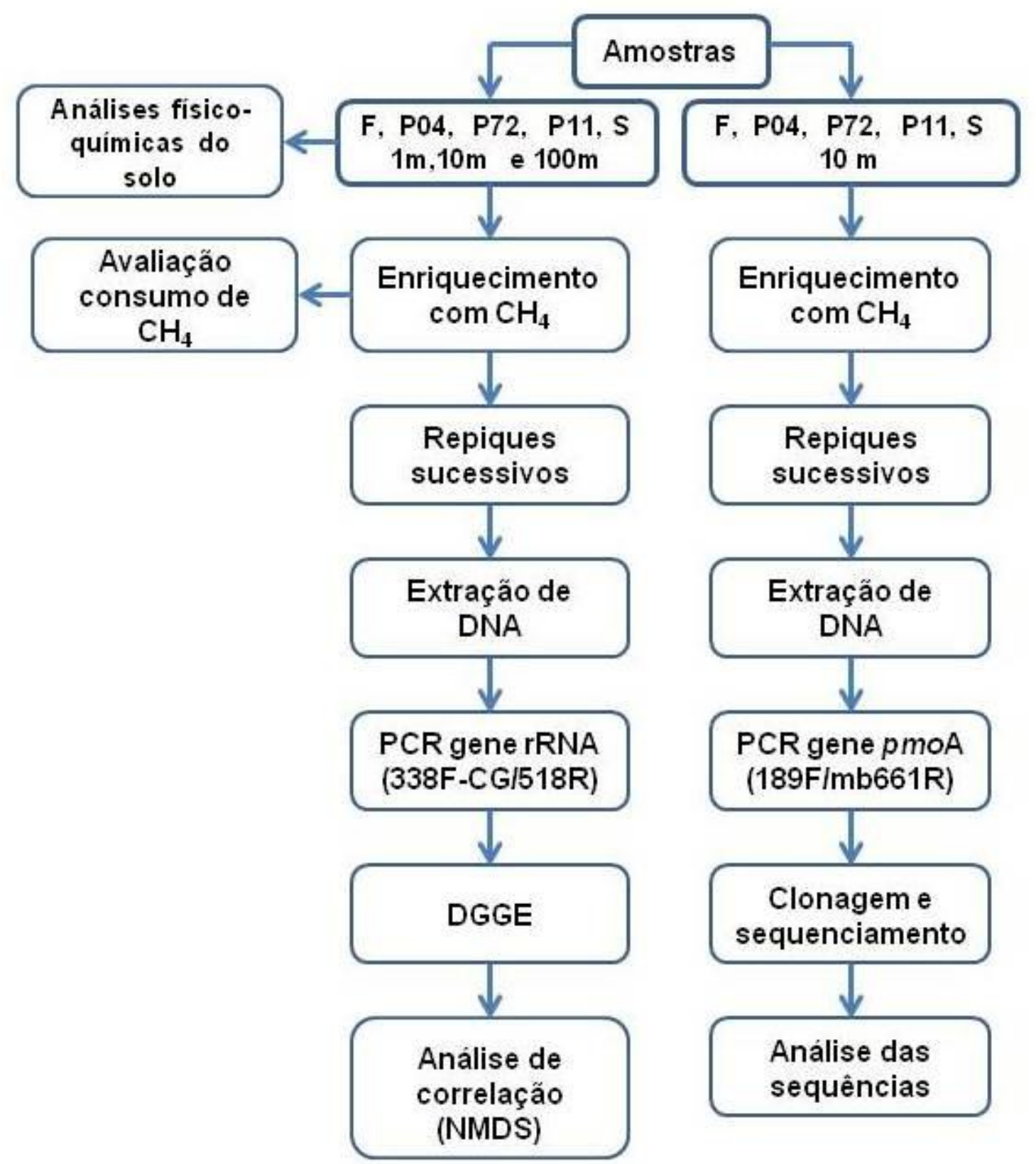

4.3 Análise dos parâmetros físico-químicos do solo

As análises físico-químicas das amostras de solo foram realizadas no Laboratório de Biogeoquímica Ambiental do Centro de Energia Nuclear na Agricultura (CENA-USP) e no 
Laboratório de Fertilidade e Classificação de Solo, da Escola Superior de Agricultura Luiz de Queiroz (ESALQ-USP).

As amostras foram secas e peneiradas (malha 100) antes de serem enviadas para o CENA-USP, onde foram realizadas as análises de Carbono e Nitrogênio totais, através do auto analisador Leco Truspec CN (St. Joseph, MI, USA). As análises de macro e micro nutrientes e parâmetros de fertilidade do solo realizadas na ESALQ-USP, utilizaram as técnicas descritas por Van Raij et al. (2001): Fósforo (P): Resina de troca de íons; Boro (B): Colorimetria; Enxofre (S): Turbidimetria; Cálcio (Ca), Magnésio (Mg), Potássio (K), Cobre $(\mathrm{Cu})$, Zinco $(\mathrm{Zn})$, Manganês $(\mathrm{Mn})$, Ferro $(\mathrm{Fe})$ : Espectrometria de Absorção Atômica; pH: $\mathrm{CaCl} 2$ 0,01 mol.1-1. Matéria Orgânica (MO) foi verificada pelo método Dicromato/colorimétrico.

\subsection{Cultivo para enriquecimento de bactérias metanotróficas}

\subsubsection{Condições de cultivo}

As culturas foram incubadas em meio mínimo mineral líquido - Nitrate Mineral Salts Medium - ATCC 1306 (NMS) -, mantidos à temperatura de $28{ }^{\circ} \mathrm{C}$, sob agitação de 150 rotações por minuto (rpm). Os frascos foram fechados com batoques de borracha (butila) e lacres metálicos.

O metano empregado foi o da marca Linde, grau analítico $(99,95 \%$ de pureza), em proporção aproximada de 1:9 metano/ar atmosférico. Para a realização da troca de atmosfera dos frascos, foi empregado o sistema de distribuição simultânea de gases, comum nos trabalhos para a manipulação de anaeróbios estritos e adaptado para a manipulação de cultivos com metanotróficas no Laboratório de Ecologia de Micro-organismos (Figura 9). Todos os gases que entraram nos frascos passaram por uma unidade filtrante com poros de $0,2 \mu \mathrm{m}$, da marca Millipore, sendo esta mais uma medida adotada para evitar a contaminação.

A ocorrência de atividade metanotrófica nos cultivos foi feita analisando-se a porcentagem de gás metano na atmosfera do frasco, através de cromatografia gasosa (Agilent, modelo HP6850A, equipado com detector de ionização de chama - GC/FID), utilizando-se $\mathrm{N}_{2}$ como gás de arraste. As análises cromatográficas foram realizadas a $40{ }^{\circ} \mathrm{C}$, por 3 minutos, sendo o tempo de retenção do metano por volta de 1,3 minutos. As amostras foram retiradas dos frascos de cultivo com seringa de $1 \mathrm{~mL}$ descartável. O volume de injeção foi de $100 \mu \mathrm{L}$. 
As áreas de pico de metano encontradas nas amostras foram comparadas com o padrão de metano 99,95\%, o qual é representado pela média das áreas de pico geradas por cinco injeções de metano puro (diretamente da tubulação). O cálculo da quantidade de metano em mmol foi realizado segundo a equação de Clapeyron para gases perfeitos ( $\mathrm{PV}=\mathrm{nRT}$ ), com a temperatura em $25{ }^{\circ} \mathrm{C}$, e o volume correspondendo ao valor total de mililitros de metano consumidos em dado período.

Figura 9 - Sistema de distribuição simultânea de gases, usado para a manipulação de micro-organismos metanotróficos - Laboratório de Ecologia de Microorganismos.

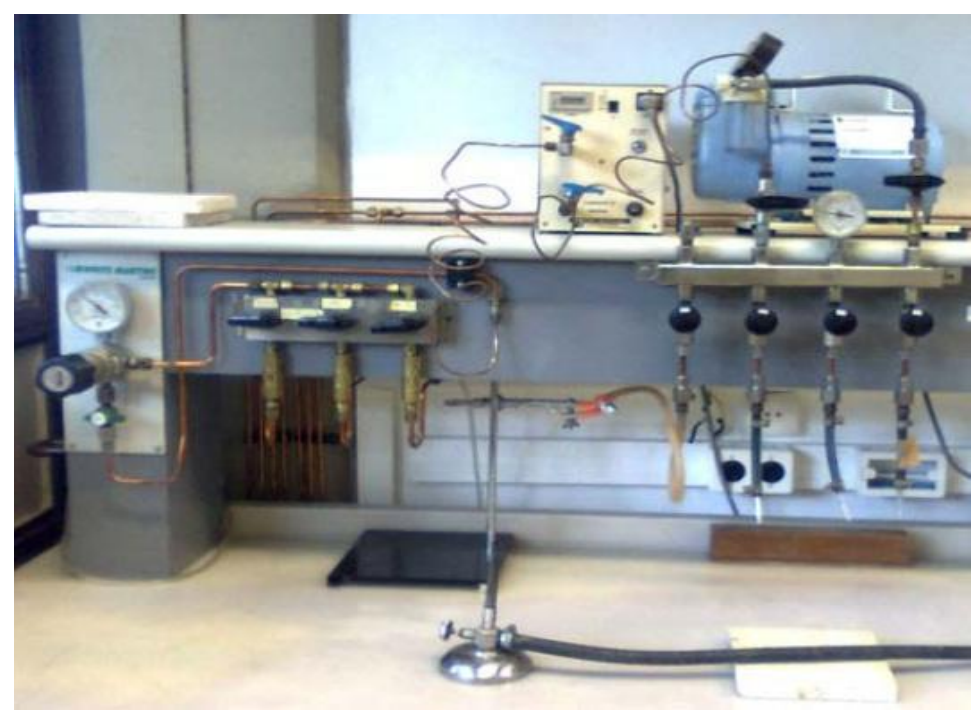

Fonte: Tessaro (2012).

\subsubsection{Enriquecimento das amostras}

Foram pesados $5 \mathrm{~g}$ de solo (em peso úmido) de cada amostra, em placas de Petri estéreis, e imediatamente transferidos para os frascos que já continham NMS. Com o objetivo de favorecer o crescimento de bactérias metanotróficas em detrimento de outras, foram realizados repiques sequenciais, com intervalos de cerca de oito dias, a partir dos frascos de enriquecimento inicial. 


\subsubsection{Diluição decimal em série}

Os frascos de cada um dos últimos repiques do enriquecimento foram amostrados para execução de diluição decimal seriada. A diluição foi realizada na faixa de $10^{-1}$ a $10^{-9}$, em frascos de $50 \mathrm{~mL}$. Os frascos das diluições tiveram também a atmosfera composta por 10\% de metano em ar atmosférico. A concentração de metano na atmosfera dos frascos foi medida periodicamente durante a incubação, a fim de verificar o consumo do gás. Após o último repique sequencial foi realizada a extração de DNA segundo Protocolo de Wilson (2001).

\subsection{Análise da diversidade de metanotróficas em solos da Amazônia}

\subsubsection{Extração de DNA dos repiques}

Para a extração de DNA, os frascos contendo as culturas foram abertos em fluxo e o meio contendo as cultura foi transferido para tubos de polipropileno de $50 \mathrm{~mL}$, após foram centrifugados a $10.000 \mathrm{rpm}$ por 10 minutos para formação do pellet que foi utilizado para extração. O protocolo utilizado para extração de DNA bacteriano foi descrito por Wilson (2001). A extração iniciou-se com o descarte do sobrenadante e a ressuspensão do pellet em $567 \mu \mathrm{L}$ de tampão TE, após ocorrendo a transferência do conteúdo para um tubo de $2 \mathrm{~mL}$. Procedeu-se, então, a adição de $30 \mu \mathrm{L}$ de solução de SDS - concentração final de $10 \%$ - e proteinase K - concentração final $20 \mathrm{mg} / \mathrm{ml}$ - após leve agitação, ocorreu 1 hora de incubação à $37^{\circ} \mathrm{C}$. Após a incubação ocorreu uma lavagem com clorofórmio-álcool isoamílico (24:1), que consistiu na adição de $700 \mu \mathrm{L}$ da referida solução, homogeneização e centrifugação por 20 min a $10.000 \mathrm{rpm}$. A fase aquosa foi transferida para novo tubo e passando então, por uma incubação de 30 min a $37{ }^{\circ} \mathrm{C}$, após adição à de $5 \mu \mathrm{L}$ de RNAse $\mathrm{A}$ - concentração final $1 \mathrm{mg} / \mathrm{mL}$. Repetiu-se, então, o processo de lavagem com clorofórmio-álcool isoamílico (24:1). Após a transferência da fase aquosa para outro tubo, ocorreu a adição de $300 \mu \mathrm{L}$ de isopropanol gelado, e centrifugação por $10 \mathrm{~min}$ a $12.000 \mathrm{rpm}$ a $4{ }^{\circ} \mathrm{C}$. O sobrenadante foi descartado e procedeu-se a última lavagem do DNA com $200 \mu \mathrm{L}$ de etanol absoluto gelado. Após a retirada completa do etanol com pipeta, os tubos permaneceram invertidos para total evaporação do etanol, após secagem, ressuspendeu-se o DNA em $30 \mu \mathrm{L}$ de água milli-Q estéril. 


\subsubsection{Detecção do gene pmoA a partir do DNA extraído dos repiques}

Para as reações de amplificação do gene $p m o A$, que codifica para uma porção conservada da enzima pMMO, foram utilizados os primers A189f (5' GGN GAC TGG GAC TTC TGG 3') (HOLMES et al., 2005) e mb661r (5' CCG GMG CAA CGT CYT TAC C 3'), desenhado por Costello e Lidstrom (1999). As reações foram preparadas com volume final de $25 \mu \mathrm{L}$, contendo cerca de $40 \mathrm{ng}$ de DNA molde, 1,5 $\mathrm{mM}$ de $\mathrm{MgCl}_{2}, 0,8 \mathrm{mM}$ de dNTPs, 0,25 $\mu \mathrm{m}$ de cada primer e $1 \mathrm{U}$ da enzima Taq DNA Polimerase Platinum (Invitrogen, Brasil). As condições da PCR foram as seguintes: desnaturação inicial a $94{ }^{\circ} \mathrm{C}$ por 5 min, seguido de 35 ciclos de $94{ }^{\circ} \mathrm{C}$ por 1 minuto, rampa de $64{ }^{\circ} \mathrm{C}$ a $57{ }^{\circ} \mathrm{C}$ por 1 minuto $\left(-0,2{ }^{\circ} \mathrm{C}\right.$ por ciclo), e 72 ${ }^{\circ} \mathrm{C}$ por 1 minuto. Uma extensão final foi realizada a $72{ }^{\circ} \mathrm{C}$ por 7 minutos. Os produtos de PCR foram verificados por meio de eletroforese em gel de agarose 1\%, e corados posteriormente à corrida, com brometo de etídeo e observação em luz ultravioleta.

Os produtos de PCR utilizados posteriormente para a construção de bibliotecas foram purificados utilizando o kit Pure Link PCR purification kit (Invitrogen, Brasil) e quantificados no espectrofotômetro NanoDrop ND-1000 (Uniscience).

\subsubsection{Construção das bibliotecas do gene pmoA}

Para construção das bibliotecas do gene pmoA foi utilizado o sistema de clonagem pGEM-T-Easy (Promega - Madison, Wisconsin, USA), de acordo com as instruções do fabricante. Foram utilizados os fragmentos amplificados em triplicata e purificados. A reação de ligação teve uma concentração apropriada de produto de PCR para obter-se uma proporção de 3:1 (mol de inserto: mol de vetor) em um volume final de $10 \mu \mathrm{L}$. Células competentes de E. coli foram transformadas com $2 \mu \mathrm{L}$ da reação de ligação utilizando-se o método de choque térmico.

As células transformadas foram plaqueadas em meio Luria Bertani - LB, contendo ampicilina $(100 \mu \mathrm{g} / \mathrm{mL})$, IPTG $50 \mu \mathrm{g} / \mathrm{mL}$ (Isopropyl $\beta$-D-thiogalactopyranoside) e X-Gal 40pg/mL (5-bromo-4-chloro-3-indolyl $\beta$-D-galactopyranoside) . Cerca de 120 colônias brancas foram selecionadas para repique numa nova placa para confirmação da coloração branca. 


\subsubsection{Sequenciamento dos clones do gene pmoA}

Os clones foram transferidos diretamente para a reação de PCR sem a necessidade de uma etapa de extração de DNA. A amplificação foi realizada utilizando-se os pares de primers M13F (5' GTT TTC CCA GTC ACG AC 3') e M13R (5' CAG GAA ACA GCT ATG AC 3') (pGEMT-Easy, manual - Promega ). A reação de PCR em volume final de $50 \mu \mathrm{L}$, continha tampão de PCR 1X, 1,7 mM de $\mathrm{MgCl}_{2}, 0,8 \mathrm{mM}$ de dNTPs, 0,3 $\mu \mathrm{M}$ de cada primer e $1 \mathrm{U}$ de Taq DNA Polimerase Platinum. As reações de amplificação foram realizadas com ciclo inicial de desnaturação a $97{ }^{\circ} \mathrm{C}$ por 3 minutos, seguido de 40 ciclos de $94{ }^{\circ} \mathrm{C}$ por 30 segundos, $60{ }^{\circ} \mathrm{C}$ por 30 segundos, e $72{ }^{\circ} \mathrm{C}$ por 90 segundos, com extensão final a $72{ }^{\circ} \mathrm{C}$ por 5 $\min$.

Os produtos de PCR foram purificados e concentrados com o kit Pure Link PCR purification kit (Invitrogen). Os produtos da purificação foram verificados em gel de agarose 1\%, quantificados no espectofotômetro NanoDrop ND-1000 e enviados para sequenciamento no Centro de Estudos do Genoma Humano (IB-USP), utilizando o sistema MegaBACE 1000. Para a reação de sequenciamento dos clones, foi utilizado o primer T7-F (5' TAA TAC GAC TCA CTA TAG GG 3') (pGEM-T-Easy, manual - Promega).

\subsubsection{Análise da diversidade através das bibliotecas construídas}

A qualidade do sequenciamento foi averiguada através da ferramenta Phred, disponível online no software Electropherogram quality analysis da EMBRAPA, e as sequências com score $<20$ foram removidas. Em seguida as sequências foram editadas manualmente no software BioEdit v7.0.9.0 (HALL et al., 1999) e então comparadas com sequências referência adquiridas nos bancos de dados "GenBank - National Center for Biotechnology Information" - NCBI (BENSON et al., 2005). As árvores filogenéticas foram criadas utilizando-se o software MEGA 4 (TAMURA et al., 2007) utilizando o método Neighbor Joining.

\subsubsection{Amplificação por PCR do gene rRNA 16S com primers com grampo}

O perfil da comunidade das amostras de solos da Amazônia em DGGE. Na reação de PCR foram empregados os primers 338F-CG (5' ACT CCT ACGGGA GGC AGC AG 3') (AMPE et al., 1999) 518R (5’ ATT ACC GCG GCT GCT GG 3') (MUYZER et al., 1993). A sequência do grampo de GC, sintetizada ao final do oligonucleotídeo 338F foi a seguinte: 5' 
CGC CCG CCG CGC GCG GCG GGC GGG GCG GGGGCA CGG GGG G 3’. As reações foram realizadas com volume final de $30 \mu \mathrm{L}$, contendo o DNA molde, tampão de PCR 1X, 1,5 $\mathrm{mM}$ de $\mathrm{MgCl}_{2}, 200 \mathrm{mM}$ de cada um dos dNTPs, 0,20 $\mu \mathrm{M}$ de cada primer e $1 \mathrm{U}$ de Taq DNA Polimerase Platinum. O programa de amplificação foi: desnaturação inicial a $94{ }^{\circ} \mathrm{C}$ por 5 minutos, 30 ciclosde $94{ }^{\circ} \mathrm{C}$ por 1 minuto, $55^{\circ} \mathrm{C}$ por 1 minuto e $72{ }^{\circ} \mathrm{C}$ por 2 minutos, e, finalmente extensão final a $72{ }^{\circ} \mathrm{C}$ por 7 minutos.

\subsubsection{Eletroforese em Gel de Gradiente Desnaturante (DGGE)}

Alíquotas de $15 \mathrm{uL}$ dos produtos amplificados com os primers 338F-CG/518R foram aplicados em gel de poliacrilamida $8 \%$ com gradiente desnaturante de $45-55 \%$. A eletroforese levou 16 horas a $60{ }^{\circ} \mathrm{C}$, a uma voltagem de $60 \mathrm{~V}$. Os géis foram corados com nitrato de prata (MAECK et al., 1997).

Os perfis de bandas dos géis de DGGE, realizado com o DNA extraído dos repiques das amostras, foram correlacionados com as variáveis físico-químicos do solo, por meio de análise de ordenação em escala multidimensional não métrica (NMDS), utilizando a análise de envfit, com objetivo de verificar uma possível influência dos fatores físico-químicos para com a comunidade oxidadora de metano.

Para realizar esta análise foram usadas as informações de presença e ausência de bandas do DGGE e as variáveis físico-químicas.

\subsection{Estudo da comunidade ativa através da aplicação da técnica de DNA-SIP}

O emprego da técnica de DNA-SIP foi realizado utilizando a amostra de pastagem P04. A escolha da amostra foi baseada nos resultados obtidos pelo projeto Amazon Rainforest Microbial Observatory: Functional Diversity,Taxonomic, Diversity, and Response to Ecossystem Conversion, que em testes com genes funcionais e rRNA16S, demonstraram que a amostra de pastagem P04 apresentava um padrão diferenciado das demais amostras. Dentre as amostras P04 $1 \mathrm{~m}$, P04 $1 \mathrm{~m}$ e P04 $100 \mathrm{~m}$, esta última foi selecionada, pois apresentou melhor rendimento de DNA(ng/uL) durante a extração, um fator importante para que o experimento de DNA-SIP pudesse ser realizado com sucesso. A Figura 10 apresenta um esquema contendo as etapas empregadas na aplicação da técnica de DNA-SIP. 
Figura 10 - Fluxograma da metodologia empregada na aplicação da técnica de DNA-SIP ${ }^{13} \mathrm{CH}_{4}$.

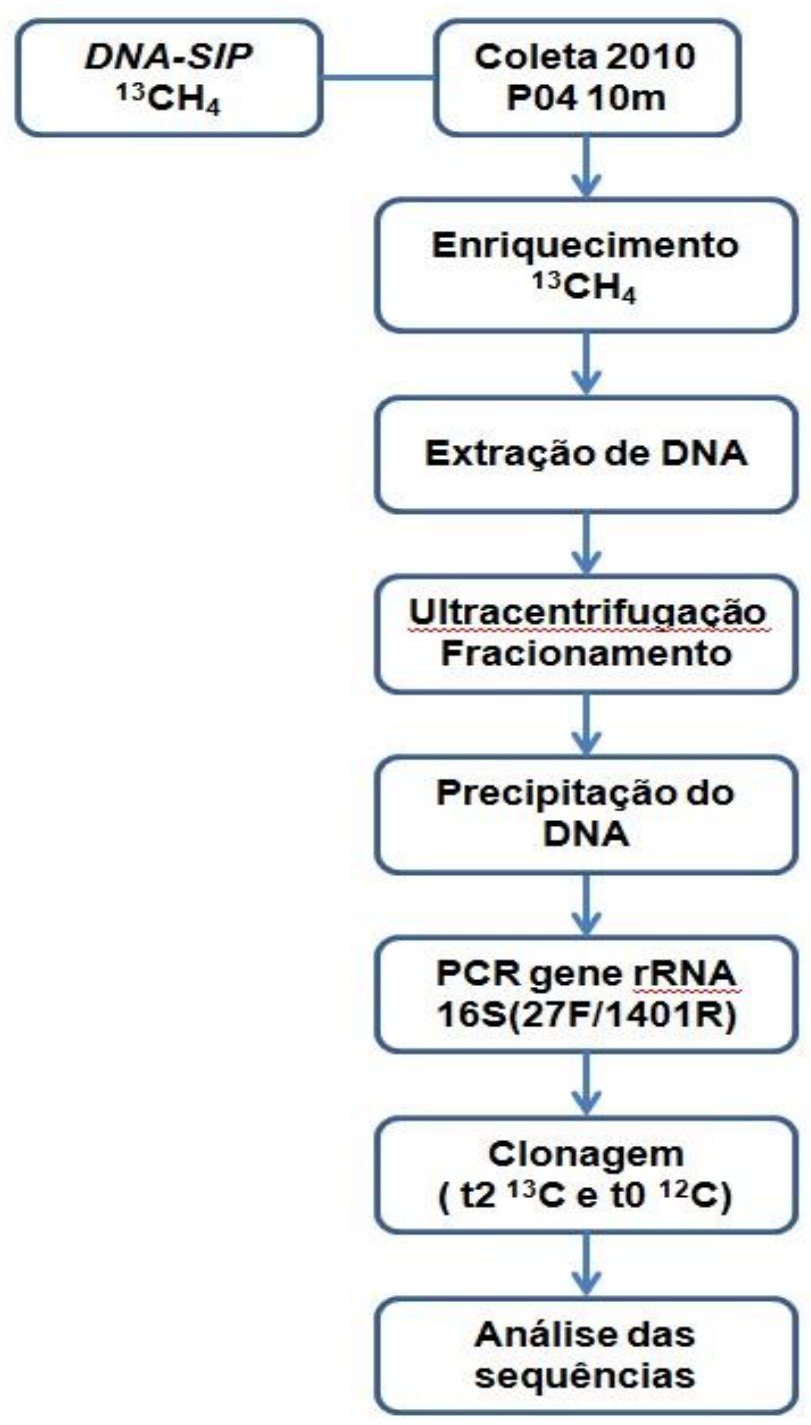

Fonte: Tessaro (2012).

\subsubsection{Microcosmos para a aplicação da técnica de $\mathrm{DNA}-\mathrm{SIP}^{13} \mathrm{CH}_{4}$}

Os microcosmos foram realizados em frascos de $100 \mathrm{~mL}$, contendo $45 \mathrm{~mL}$ de meio mínimo mineral (NMS) e $5 \mathrm{~g}$ (peso úmido) de solo. Os frascos foram fechados com batoques de butila e lacres metálicos. Um total de 12 frascos foi montado, cinco dos quais receberam ${ }^{13} \mathrm{CH}_{4}$, os outros cinco receberam ${ }^{12} \mathrm{CH}_{4}$, e os dois frascos restantes serviram como controles para a ausência de produção de metano nos microcosmos, e por isso não receberam metano 
(Figura 11). Após o fornecimento de metano (cerca de $10 \%$ em ar atmosférico) a incubação foi realizada à temperatura de $30{ }^{\circ} \mathrm{C}$, sob agitação de $150 \mathrm{rpm}$, no escuro.

Para recuperar o DNA do material de cada tempo de enriquecimento, um par de frascos (um incubado com ${ }^{13} \mathrm{CH}_{4}$ e outro com ${ }^{12} \mathrm{CH}_{4}$ ) era sacrificado conforme o consumo atingia um valor acumulado de 0,2;0,6;1,0 e 1,8 mmol/frasco, respectivamente (t1, t2, t3, t4) (Figura 11). No início da incubação um par de frascos com ${ }^{13} \mathrm{CH}_{4}$ e outro com ${ }^{12} \mathrm{CH}_{4}$, foram sacrificados, sendo chamados de t0. $\mathrm{O}$ t0 equivale à amostra original (tempo zero).

Os frascos sacrificados foram abertos em ambiente estéril e o conteúdo foi despejado em tubos de polipropileno estéreis sendo, imediatamente centrifugados a $10.000 \mathrm{rpm}$ por 40 minutos, à $4{ }^{\circ} \mathrm{C}$. O sobrenadante foi descartado e do pellet foi realizada a extração de DNA.

Figura 11 - Esquema simplificado dos microcosmos realizados para o emprego da técnica de DNA-SIP.

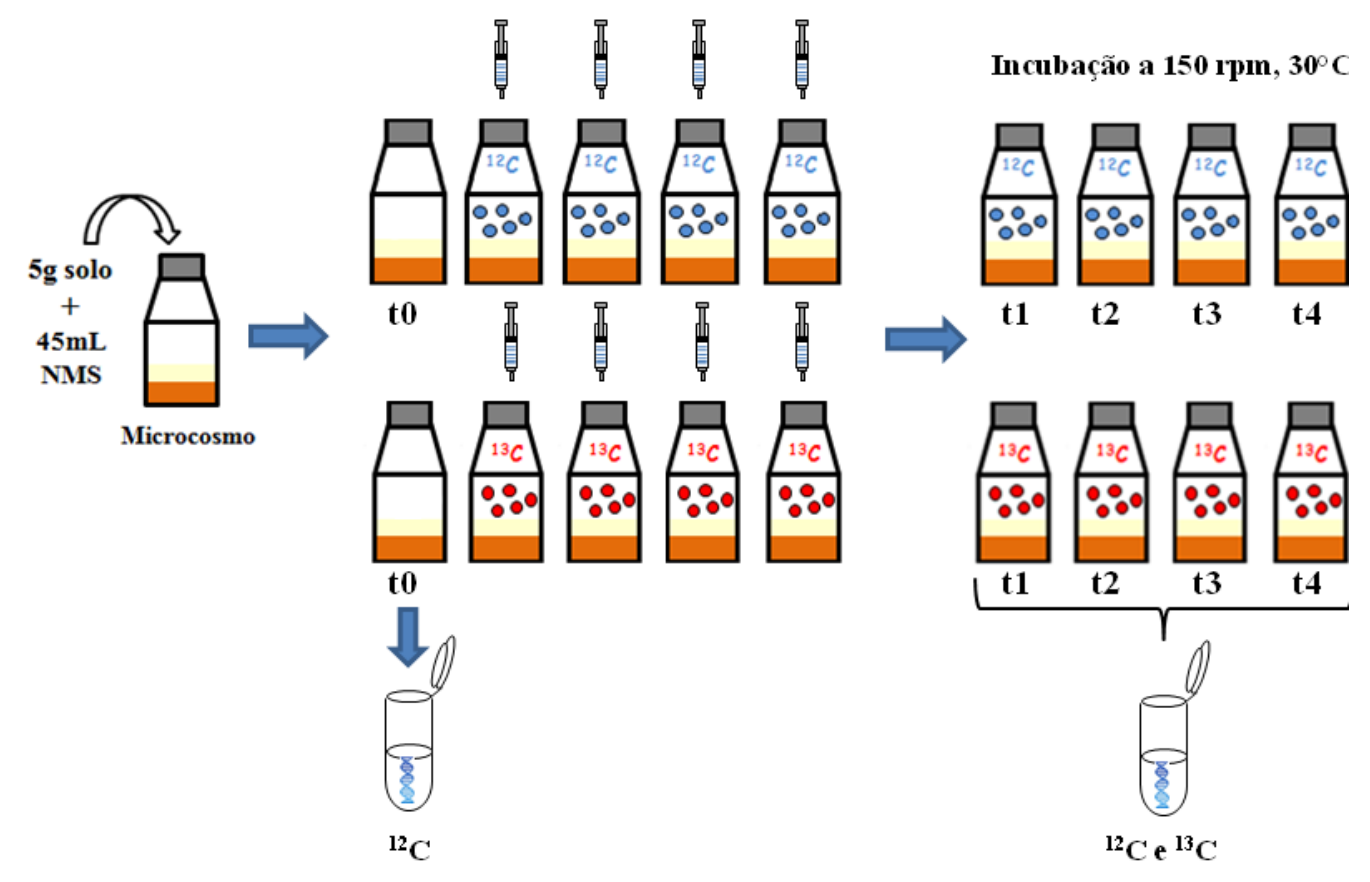

Fonte: Adaptado de Saia et al. (2010).

\subsubsection{Extração de DNA}

As extrações de DNA dos solos recuperados dos microcosmos do DNA-SIP foram realizadas utilizando-se o kit de extração PowerLyzer PowerSoil DNA Isolation Kit (MO 
BIO, Laboratories Inc, USA). Os produtos de todas as extrações foram verificados em gel de agarose $1 \%$ e quantificados no espectofotômetro NanoDrop ND-1000.

\subsubsection{Fracionamento do DNA extraído dos enriquecimentos}

Para o fracionamento do DNA extraído dos frascos de enriquecimento utilizou-se $10 \mu \mathrm{L}$ de DNA, correspondendo a $500 \mathrm{ng}$ de ${ }^{12} \mathrm{C}$-DNA e ${ }^{13} \mathrm{C}$-DNA, estes aplicados em tubos de ultracentrífuga de 2,2 $\mathrm{mL}$, contendo $1,8 \mathrm{~mL}$ de CsTFA/GB com densidade de $1,61 \mathrm{~g} / \mathrm{mL}$ (SAIA et al., 2010). Tubos brancos também foram preparados, contendo $10 \mathrm{uL}$ de água MilliQ estéril ao invés de DNA. Os tubos foram ultracentrifugados em ultracentrífuga de bancada (Optima TLX 120000) com rotor de ângulo fixo (TLA 120.2 - específico para $2.2 \mathrm{ml}$ tubos). As condições de ultracentrifugação foram de $64.000 \mathrm{rpm}$ por $40 \mathrm{~h}$, à $20{ }^{\circ} \mathrm{C}$. A coleta das frações foi realizada com sucesso por fracionamento com água Milli-Q estéril, do topo à base dos tubos, utilizando o sistema de fracionamento acoplado à bomba de infusão de seringa. Um total de 20 frações, contendo $100 \mu \mathrm{L}$ de amostra em cada, foram coletadas a cada 30 segundos à vazão de $0,2 \mathrm{~mL} / \mathrm{min}$. A densidade dos tubos brancos foi determinada pela pesagem de $40 \mathrm{ul}$ de amostra (SAIA et al., 2010). A Figura 12 mostra um esquema simplificado do processamento do DNA obtido das frações do DNA-SIP, incluindo fracionamento e construção de arvores filogenética. 
Figura 12 - Esquema simplificado do processamento do DNA obtido das frações do DNASIP.
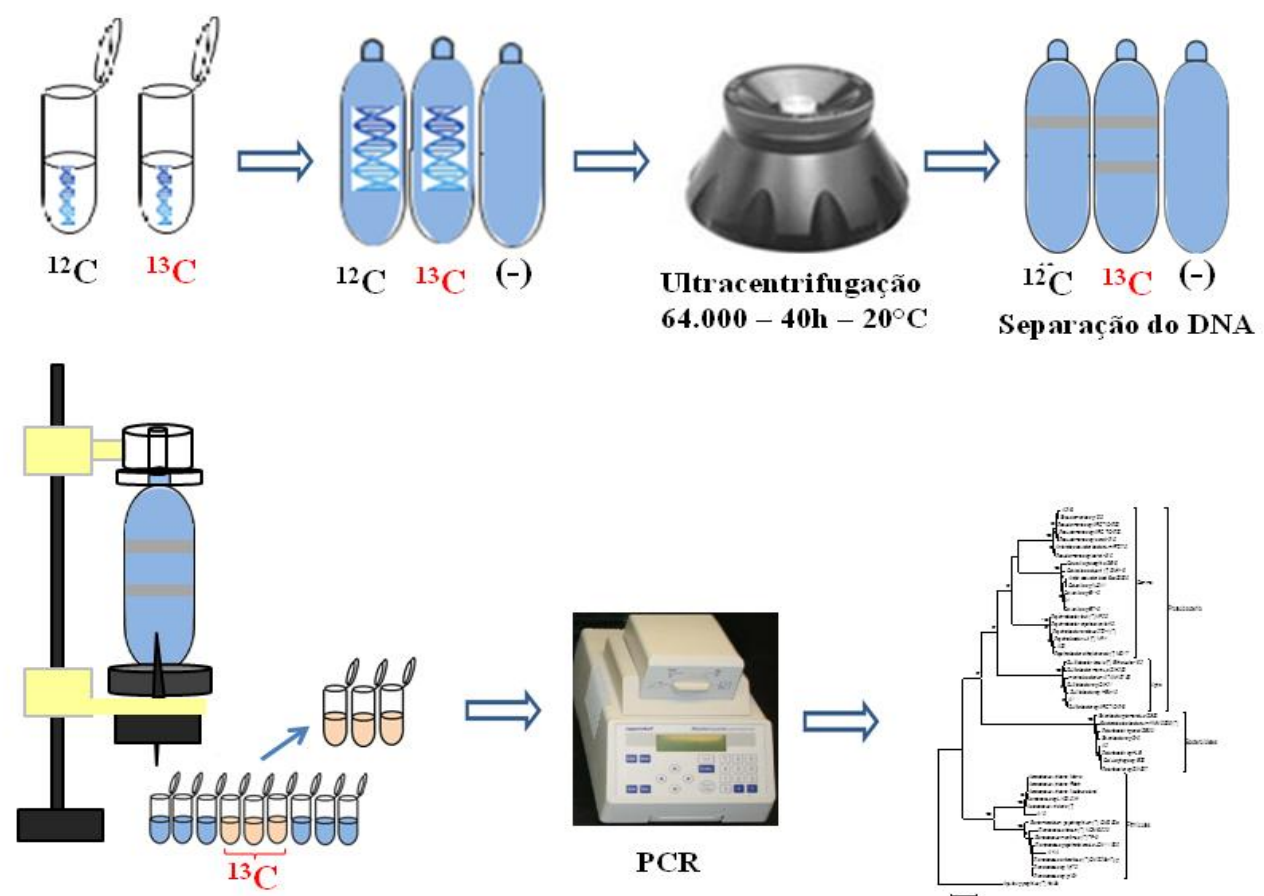

Fracionam ento

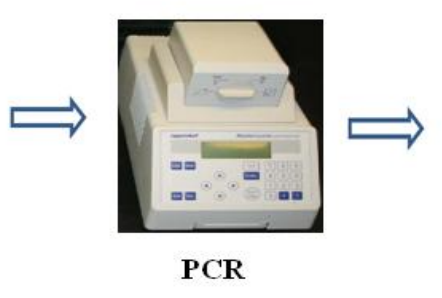

Árvore filogenética

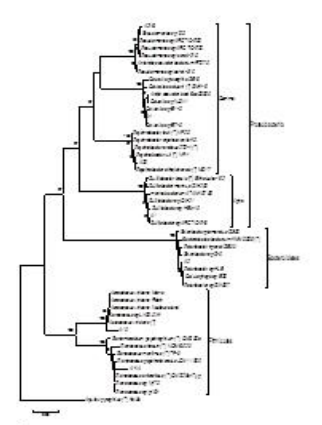

\subsubsection{Precipitação do DNA}

O DNA de cada fração foi precipitado pela adição de $500 \mathrm{uL}$ de isopropanol gelado, permanecendo overnight a $4{ }^{\circ} \mathrm{C}$. Os microtubos contendo o material foram centrifugados a $14.000 \mathrm{rpm}$ por 30 minutos, à temperatura de $4{ }^{\circ} \mathrm{C}$. Após, os precipitados passaram por uma lavagem com etanol $70 \%$ e os tubos foram centrifugados novamente por 15 minutos, a $4{ }^{\circ} \mathrm{C}$. O sobrenadante foi removido pela inversão dos tubos (SAIA et al., 2010). Após, procedeu-se a quantificação do DNA de cada fração, que foi realizada utilizando o PicoGreen® ds-DNA Quantitation Kit (Invitrogen, Brasil), seguindo as instruções do fabricante. 


\subsubsection{Amplificação por PCR gene rRNA 16S a partir do DNA obtido no DNA-SIP}

Foram amplificados os fragmentos existentes no DNA obtido das frações de DNA-SIP dos tempos de incubação t0 e t2. Para as reações de amplificação, foram utilizados os primers universais para o domínio bactéria 27F (5' AGA GTT TGA TCM TGG CTC AG 3') (LANE, 1991) e 1401R (5' CGG TGT GTA CAA GAC CC 3') (FELSKE et al., 1996). Para a construção das bibliotecas, a PCR foi realizada em triplicata, utilizando diferentes concentrações de DNA molde. As reações foram preparadas contendo volume final de $25 \mu \mathrm{L}$, tampão de PCR 1X, 1,5 mM de $\mathrm{MgCl}_{2}, 0,8 \mathrm{mM}$ de dNTPs, 0,2 $\mu \mathrm{M}$ de cada iniciador e $1 \mathrm{U}$ da enzima Taq DNA Polimerase Platinum.

As condições de PCR foram: desnaturação inicial a $94{ }^{\circ} \mathrm{C}$ por 5 minutos, 30 ciclos de $94{ }^{\circ} \mathrm{C}$ por 30 segundos, $55{ }^{\circ} \mathrm{C}$ por 30 segundos, e $72{ }^{\circ} \mathrm{C}$ por 90 segundos e finalmente extensão final a $72{ }^{\circ} \mathrm{C}$ por 7 minutos. As reações foram realizadas no termociclador Mastercycler Personal (Eppendorf, Alemanha).

Os produtos de PCR foram verificados em gel de agarose 1,5\%, seguido de coloração em brometo de etídeo e observação em luz ultravioleta. Os produtos utilizados posteriormente para a construção de bibliotecas foram purificados utilizando o kit Pure Link PCR Purification Kit (Invitrogen) e quantificados no espectrofotômetro NanoDrop ND-1000.

\subsubsection{Construção das bibliotecas do gene rRNA $16 \mathrm{~S}$}

O sistema de clonagem pGEM-T-easy (Promega ) foi utilizado para clonagem do gene rRNA 16S, de acordo com as instruções do fabricante. A reação de ligação teve uma concentração apropriada de produto de PCR para obter-se uma proporção de 3:1 (mol de inserto: mol de vetor) em um volume final de $10 \mu \mathrm{L}$. A clonagem procedeu-se conforme descrito na seção 4.5.3.

\subsubsection{Sequenciamento dos clones do gene rRNA $16 \mathrm{~S}$}

Após a incubação das placas, as colônias brancas correspondentes aos possíveis clones positivos, foram transferidas individualmente para placas de 96 poços contendo $50 \mu \mathrm{L}$ de tampão TE 1X, com o auxílio de palitos autoclavados. Estas placas foram então submetidas à temperatura de $95{ }^{\circ} \mathrm{C}$ por 15 minutos em termociclador, para promover a lise celular, 
possibilitando a liberação do DNA. Um microlitro desse volume foi utilizado para confirmação da presença do inserto através da amplificação por PCR.

A amplificação foi realizada utilizando-se os pares de primers M13F (5' GTT TTC CCA GTC ACG AC 3') (pGEM-T - Promega) e em substituição do primer M13R foi utilizado o primer reverse 1401R (5' CGG TGT GTA CAA GAC CC 3') (FELSKE et al., 1996), visando assim obter apenas os fragmentos inseridos no vetor no sentido forward (regiões hipervariáveis V1-V3). A reação de PCR foi a mesma descrita na seção 4.5.4.

Os produtos de PCR foram purificados e concentrados com o kit Pure Link PCR purification kit (Invitrogen). Para a reação de sequenciamento dos clones, foi utilizado o primer T7-F (5' TAA TAC GAC TCA CTA TAG GG 3') (pGEM-T-Easy - Promega).

\subsubsection{Análise da diversidade através das bibliotecas construídas}

A edição e análise das sequências do gene rRNA 16S foram avaliadas através da ferramenta Phred, disponível online no software Electropherogram quality analysis da EMBRAPA, conforme descrito na seção 4.5.5. 


\section{RESULTADOS E DISCUSSÃO}

\subsection{Influência de fatores ambientais sobre a estrutura da comunidade oxidadora de $\mathrm{CH}_{4}$}

A conversão de floresta tropical a pastagem gera com frequência alterações nas propriedades do solo. Já foi mostrado em trabalhos anteriores, que na Fazenda Nova Vida a retirada da vegetação natural e o estabelecimento de pastagens promovem mudanças nas características do solo, como; alterações na porosidade, no $\mathrm{pH}$, e quantidade de nutrientes disponíveis (DE MORAES et al., 1996).

Muitos estudos que analisam as características do solo e as mudanças ocorridas após a conversão de floresta a pastagem, já foram realizados na Amazônia (DE MORAES et al., 1996; FERNANDES et al., 2002; HERPIN et al., 2002; NEILL et al., 1997). Desta forma, aqui serão discutidas principalmente as variáveis que apresentaram correlação significativa no teste realizado e as variáveis mais relevantes para a comunidade metanotrófica.

$\mathrm{O} \mathrm{pH}$ é um fator importante para a comunidade metanotrófica ( EINOLA; KARHU; RINTALA, 2008). Estudo realizado por Fernandes et al. (2002) na Fazenda Nova Vida, apresenta resultados que indicam que a conversão de floresta a pastagem induz a um aumento nos níveis de $\mathrm{pH}$. Segundo o próprio autor este fato pode ocorrer devido a grande quantidade cinzas geradas a partir das queimadas da vegetação original. Paula (2012) em estudo recente realizado com as mesmas amostras utilizadas neste trabalho, demonstra que existe uma pequena variação do $\mathrm{pH}$ entre solos avaliados, não havendo aumento significativo nas pastagens em relação à floresta primária. Como podemos verificar no Apêndice $\mathrm{B}$, os níveis de $\mathrm{pH}$ das pastagens variou entre 4,0 e 5,0, já o apresentado pelas florestas primária e secundária ficou entre 3,6 e 4,5, sendo então um pouco menor em relação às florestas.

A variação nas quantidades de $\mathrm{C}$ e $\mathrm{N}$ do solo após a conversão de floresta a pastagem, não apresenta resultados congruentes entre os estudos já realizados. Alguns estudos relatam um aumento nas quantidades de $\mathrm{C}$ e $\mathrm{N}$ após a conversão de floresta a pastagem (DE MORAES et al., 1996; HERPIN et al., 2002). Outros trabalhos, porém não apresentam os mesmos resultados. Neill et al. (1997), sugere que o aumento de C e $\mathrm{N}$ não foi significativo para a maioria das pastagens, sendo que em alguns casos foi observada até uma redução. Paula (2012) não verificou alterações significativas nos conteúdos de $\mathrm{C}$ e $\mathrm{N}$ entre as florestas e as pastagens. Os fatores sugeridos para esta divergência dos resultados obtidos nestes estudos são: a variação entre os solos e o e tipo de manejo utilizado em cada local de estudo. 


\subsubsection{Correlações entre os fatores físico-químicos e a estrutura da comunidade oxidadora de $\mathrm{CH}_{4}$}

As propriedades do solo são atributos importantes para a determinação da estrutura e composição da comunidade microbiana (HARTMAN et al., 2008; REEVE et al., 2010), afetando também a função desta comunidade (JESUS et al., 2009).

Com os resultados obtidos com o emprego da técnica de DGGE, juntamente com as variáveis físico-químicas, foi realizada uma análise de ordenação em escala multidimensional não métrica (NMDS), com objetivo de verificar uma possível influência dos fatores físicoquímicos para com a comunidade oxidadora de metano. Para realizar esta análise foram usadas as informações de presença e ausência de bandas do DGGE e as variáveis físicoquímicas.

Figura 13 - NMDS da estrutura da comunidade oxidadora de metano, determinada por DGGE e correlação com variáveis ambientais.

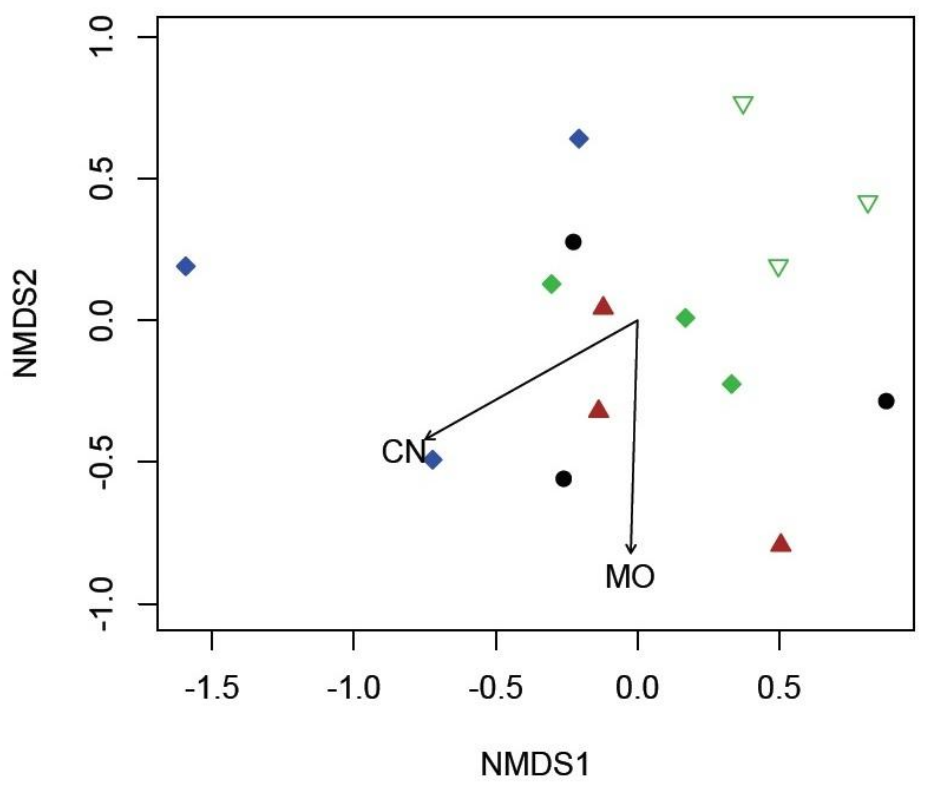

$\triangle \mathrm{P} 72 \nabla \mathrm{S} \bullet \mathrm{P} 11\rangle \mathrm{F}\langle\mathrm{P} 04$

Somente as variáveis com correlação significativa $(p<0,05)$ estão apresentadas na figura. Índice de dissimilaridade: Bray-Curtis. Stress $=0,08$ 
Os dois fatores físico-químicos que tiveram correlação significativa com a estrutura de NMDS estão apresentados em forma de gráfico de pontos na Figura 13. Este gráfico também possibilita uma visualização mais clara das variações entre os sítios de amostragem.

De acordo com a análise envfit (Figura 13) as amostras se organizam de forma dispersa, indicando baixa similaridade entre si. As amostras de floresta secundária apresentam menor variação entre si quando considerado amostras de diferentes distâncias, sugerindo que a comunidade oxidadora de metano destas amostras pode ser mais homogênea entre si.

Índices maiores de $\mathrm{C} / \mathrm{N}$ tiveram relação com uma amostra de pastagem $\mathrm{P} 04$. A relação $\mathrm{C} / \mathrm{N}$ pode afetar significativamente o processo de oxidação do metano (BOECKX; VAN CLEEMPUT, 1996). As bactérias metanotróficas absorvem nitrogênio em forma de nitrato ou amônia. Respectivamente são assimilados $1 \mathrm{Mol}$ de nitrogênio paralelamente a $4 \mathrm{Mol}$ de carbono. Algumas ligações do nitrogênio como cloreto de amônio ou nitrito, inibem a oxidação de metano, a amônia é também conhecida por ter um efeito inibitório na oxidação do metano. Esta inibição é o resultado da competição dos substratos metano e amônia em relação à enzima metano mono-oxigenase (MMO). A adição de amônia favorece as bactérias nitrificantes e esta pode anular as atividades das metanotróficas, resultando, assim, uma redução da taxa de oxidação do metano ((BOECKX; VAN CLEEMPUT, 1996).

O teor de matéria orgânica (MO) tem relação com as amostras de pastagem P11 e P72. Solos com alta quantidade de matéria orgânica apresentam geralmente uma maior taxa de oxidação do metano. A presença da matéria orgânica aumenta a porosidade do solo, beneficiando o processo de oxidação. Contudo, a quantidade de água requerida para a otimização da atividade metanotrófica aumenta (ZEISS, 2006; CHRISTOPHERSEN et al., 2004).

\subsection{Avaliação de consumo de metano}

$\mathrm{O}$ enriquecimento das amostras teve como objetivo a avaliação de consumo de $\mathrm{CH}_{4}$ por meio de cromatografia gasosa, e a extração de DNA para amplificação dos genes pmoA e rRNA 16S para a aplicação da técnica de DGGE. O cultivo foi realizado em meio NMS, em frascos com atmosfera controlada, e mantidos sob temperatura de $28{ }^{\circ} \mathrm{C}$.

O meio NMS é um meio utilizado para o crescimento, enriquecimento e isolamento de bactérias metanotróficas (MARTINEAU; WHYTE; GREER, 2010), sendo amplamente usado para cultivo e isolamento destes micro-organismos (BOWMAN, 2006), como por exemplo: Methylovulum miyakonense (IGUCHI; YURIMOTO; SAKAI, 2011), Methylocystis hirsuta 
(LINDNER et al., 2007), Methylocella silvestris (DULFIELD et al., 2003) e Methylocystis rosea (WARTIAINEN et al., 2006 ) entre outros.

Os enriquecimentos foram realizados quatro dias após a coleta do solo, pois segundo estudo realizado por Bowman (2006), a maioria das bactérias metanotróficas resistem apenas alguns dias sem receber adição de metano. O consumo se estabeleceu rapidamente, sendo que o início do consumo foi verificado após 24 h de incubação, conforme é possível verificar na Figura 14. 
Figura 14 - Avaliação do consumo de metano por cromatografia gasosa
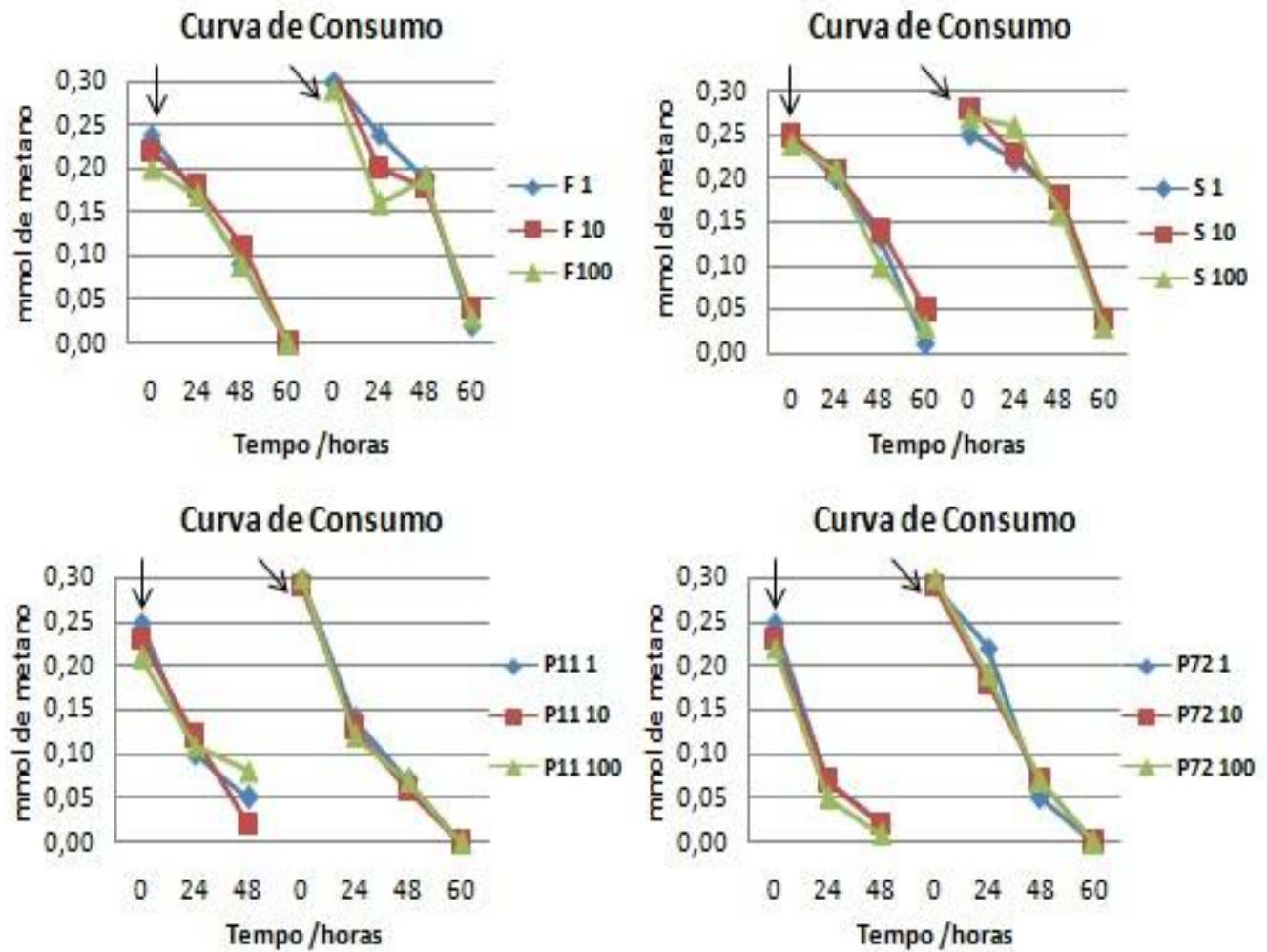

Curva de Consumo
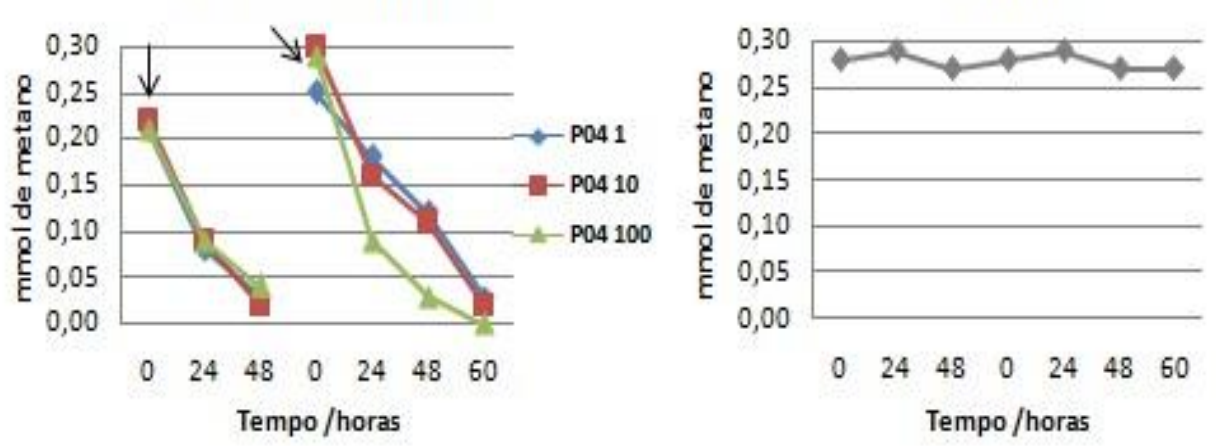

O consumo de metano está apresentado em mmol. As flechas indicam adição de metano nos frascos. O gráfico apresenta os resultados para os cinco sítios estudos, sendo que cada sítio contém amostras de 1 $\mathrm{m}, 10 \mathrm{~m}$ e $100 \mathrm{~m}$.

A Figura 14 mostra os resultados de consumo de metano apresentado pelas doze amostras utilizadas, sendo três amostras pertencentes a cada sítio de amostragem. Os resultados revelam que todas as amostras apresentam consumo de metano, indicando que a 
comunidade metanotrófica está presente e é ativa in situ. As amostras de pastagens (P11, P72 e P04) apresentaram um consumo de metano mais rápido, sendo que em 48 horas haviam consumido praticamente todo metano adicionado, ou seja, 0,25 $\mathrm{mmol} \mathrm{de} \mathrm{CH}_{4}$, enquanto as amostras de floresta primária $(\mathrm{F})$ e floresta secundária $(\mathrm{S})$ apresentaram um consumo mais lento, levando 60 horas para consumir todo metano adicionado. Dentro de cada sítio as amostras apresentaram consumo semelhante entre si.

A mudança no uso do solo pode alterar suas características, e consequentemente a comunidade microbiana presente (JESUS et al., 2009; LAMMEL, 2011; SIQUEIRA et al., 2010). Com a conversão de floresta a pastagem, pode ocorrer uma compactação do solo com o tropel do gado, diminuindo assim a aeração do solo, propiciando uma maior produção de metano pelas arquéias metanogênicas (STEUDLER et al., 1996), elevando assim a taxa de metano em locais de pastagem, fatores estes que podem alterar a quantidade disponível de metano no local.

Alterações na concentração de metano disponível podem gerar uma modificação da comunidade metanotrófica dominante, pois podem existir duas populações diferentes de metanotróficas em solos expostos a concentrações diferentes de metano, sendo que uma população pode ter alta afinidade e outra de baixa afinidade ao gás (BENDER; CONRAD, 1994; DORR; GLASSER; KOLB, 2010). Segundo Bengtson et al. (2009) a concentração de $\mathrm{CH}_{4}$ no local é um fator determinente para a taxa de oxidação de $\mathrm{CH}_{4}$, assim como a composição da comunidade metanotótrófica.

Estudos ambientais e experiências com culturas realizadas em laboratório, indicam que metanotróficas do tipo I são dominantes sobre metanotróficas do tipo II em ambientes com baixas concentrações de metano, enquanto metanotróficas do tipo II dominam ambientes de com altas concentrações de metano (GRAHAM et al., 1993; HANSON; HANSON, 1996; HENCKEL et al., 2000).

Outros fatores também são determinantes para a taxa de oxidação de metano, e também podem sofrer alterações com a modificação no uso do solo, como: a temperatura, o pH do solo e o teor de umidade, além do acesso aos nutrientes (BENDER, 1995; HUMER; LECHNER, 2003; SINGH et al., 2009; VISVANATHAN et al., 1999). A densidade e porosidade do solo também possuem forte influência sobre as taxas de oxidação de metano (TATE et al., 2006).

Estudos realizados na Fazenda Nova Vida relatam que solos florestados mantêm seu consumo de $\mathrm{CH}_{4}$ de forma regular durante as estações de chuva e seca, enquanto, solos de pastagem apresentam maior emissão de metano para atmosfera nas estações chuvosas 
(STEUDLER et al., 1996). Segundo Fernandes et al. (2002), as taxas de consumo de metano e de liberação de metano para a atmosfera estão fortemente associadas com as estações de seca e de chuva.

Knief et al. (2005) apresentam resultados que indicam que metanotróficas do gênero Methylocystis possuem maior capacidade de se adaptar em locais com baixas concentrações de metano (10 e 100 ppmv de metano), enquanto os demais grupos exigem uma quantidade metano (100 a 1000 ppmv de metano) para manter seu crescimento. Este estudo também mostra que metanotróficas do tipo II são mais adpatáveis as alterções nas concentrações de metano do solo.

Tratando-se de diferentes formas de uso do solo, alguns estudos estão sendo realizados. Tate et al. (2007), apresentam um estudo onde o solo de pastagem foi submetido a reflorestamento com Pinus radiata, resultando num aumento da oxidação de metano pelo solo e uma modificação na estrutura da comunidade metanotrófica, tornando as metantróficas de tipo I predominantes sobre as do tipo II. Porém outro estudo realizado na Nova Zelândia em locais de relforestamento com Pinus radiata, demonstra que metanotróficas do tipo II são dominantes e mais ativas em locais reflorestados e com arbustos, enquanto metanotróficas do tipo I são mais presentes em locais de pastagens (SINGH et al., 2007).

Os estudos sobre fluxo de $\mathrm{CH}_{4}$ em regiões florestadas e de pastagens, já realizados até o momento não observam um padrão consistente para consumo e emissões de $\mathrm{CH}_{4}$ (FERNANDES et al., 2002). Os resultados encontrados neste trabalho indicam haver um consumo mais rápido de metano pelos locais de pastagens, o que pode ter sido gerado por diversos fatores, como: alterações na concentração de metano disponível, a mudança nos padrões físico-químicos após a conversão de floresta a pastagem, além de uma possível mudança na comunidade metanotrófica dominante.

\subsection{Acesso à diversidade funcional de bactérias metanotróficas, através da construção de bibliotecas do gene $p m o A$}

Para acessar a diversidade funcional de bactérias metanotróficas foram construídas bibliotecas do gene pmoA. O DNA de uma amostra de cada sítio $(10 \mathrm{~m})$ foi utilizado como molde para reação de PCR com os primers A189f e mb661r 
O sequenciamento permitiu verificar a ocorrência de representantes dos gêneros Methylosinus e Methylocystis, pertencentes à família Methylocystaceae inseridas na classificação de metanotróficas do tipo II, além dos gêneros Methylobacter, Methylomicrobium e Methylococcus (Tabela 1 e Figura 15), pertencentes à família Methylococcaceae, classificadas como metanotróficas do tipo I. A maioria das sequências é relacionada a clones de solo e tiveram mais de $90 \%$ de similaridade com sequências depositadas no banco de dados do NCBI.

Tabela 1 - Gêneros de bactérias metanotróficas encontradas em cada sítio.

\begin{tabular}{lccccc}
\hline $\begin{array}{c}\text { Gêneros } \\
\text { encontrados }\end{array}$ & $\begin{array}{c}\mathbf{F} \text { (n }^{\circ} \\
\text { clones) }\end{array}$ & $\begin{array}{c}\mathbf{S}\left(\mathbf{n}^{\circ}\right. \\
\text { clones) }\end{array}$ & $\begin{array}{c}\mathbf{P 1 1}\left(\mathbf{n}^{\circ}\right. \\
\text { clones) }\end{array}$ & $\begin{array}{c}\text { P72 } \text { (n }^{\circ} \\
\text { clones) }\end{array}$ & $\begin{array}{c}\text { P04 (n } \\
\text { clones) }\end{array}$ \\
\hline Methylocystis & 11 & 16 & 29 & - & 33 \\
\hline Methylosinus & 9 & 1 & - & 20 & 1 \\
\hline Methylomicrobium & 1 & - & 2 & - & - \\
\hline Methylobacter & 12 & 4 & 2 & - & - \\
\hline Methylococcus & - & 3 & - & - & - \\
\hline
\end{tabular}

As sequências obtidas a partir das bibliotecas do solo de floresta primária, floresta secundária e pastagens foram agrupadas em sua maioria com sequências relacionadas à família Methylocystaceae. O sítio P72 apresentou todas as sequências agrupadas com o gênero Methylosinus, enquanto os sítios P11 e P04 foram agrupados predominantemente com o gênero Methylocystis. As florestas primária e secundária apresentaram os clones agrupados com um maior número de gêneros, mas também possuem um predomínio maior de metanotróficas do tipo II. Segundo Menyailo et al. (2008) metanotróficas do tipo II costumam ser predominantes em solos florestados e de pastagens. Resultados semelhantes também já foram apresentados por Knoblauch et al. (2008), em estudos realizados no norte da Sibéria, onde florestas e pastagens apresentavam predomínio de metanotróficas do tipo II.

Os resultados obtidos neste trabalho indicam que a floresta secundária apresenta uma diversidade em número de gêneros semelhante a floresta primária, sugerindo ter ocorrido um restabelecimento da comunidade metanotrófica após o abandono do uso do solo como 
pastagem. Segundo Paula (2012), em trabalho realizado na mesma região da Amazônia, a estrutura da comunidade de genes funcionais do solo se altera, seguindo o estabelecimento de pastagens, e tende a ser recuperada com o crescimento da floresta secundária. Em estudo realizado na Mata Atlântica, Dorr et al. (2010) apresentam resultados que também sugerem haver uma restauração da comunidade metanotrófica original após a arborização.

Fatores importantes já foram observados em outros estudos, segundo Abell et al. (2009), metanotróficas do tipo II não tem sua abundância significativamente afetada pela criação de gado, enquanto metanotróficas do tipo I se mostram mais sensíveis às mudanças climáticas e às alterações no uso do solo. Knief et al. (2005), em estudo realizado em solos de floresta da Tailândia, sugerem que comunidades microbianas de solos tropicais costumam apresentar uma capacidade maior de se recuperar do que comunidades de solos de locais temperados, após o abandono do uso do solo pela atividade agrícola.

$\mathrm{O}$ gênero Methylocystis encontrado em maior número neste trabalho, tem sido largamente detectado em diferentes locais do mundo, como; nas florestas tropicais da Tailândia (KNIEF et al., 2005), nos solos da Dinamarca (BOURNE; MCDONALD; MURRELL, 2001), em solos do Pantanal brasileiro (HOLMES et al., 1999), em locais de florestas da Alemanha e Holanda (KNIEF et al., 2003), em aterro sanitário (CÉBRON et al., 2007b), além de pastagens da Nova Zelândia (SINGH et al., 2007).

A estrutura da comunidade metanotrófica sofreu influência de fatores ambientais, indicando que as mudanças ocorrem no sentido de favorecer grupos mais adaptados e adaptáveis às condições disponíveis. Entretanto existe uma dificuldade em prever recuperações significativas no sistema amazônico baseando-se em florestas secundárias, pois com frequência estas são derrubadas novamente (DAVIDSON et al., 2012).

Os resultados apresentados são suficientes para discutir as diferenças entre grupos dominantes de bactérias metanotróficas acessadas nas amostras coletadas. Porém, é importante observar que as condições de cultivo podem ter colaborado para a seleção destes grupos. Lembrando que alguns grupos de bactérias metanotróficas, como Crenothrix polyspora e aqueles incluídos no Filo Verrucomicrobia, podem não terem sido detectados, porque estes organismos possuem um gene pmoA atípico, que passou a ser acessado apenas através da utilização de primers modificados e/ou condições pouco restritivas de PCR (POL et al., 2007; STOECKER et al., 2006).

$\mathrm{Na}$ Fazenda Nova Vida, a conversão de floresta para pastagem é geralmente acompanhada de uma mudança no fluxo anual de metano no solo, o qual deixa de agir como 
sumidouro, passando a ser fonte deste gás (STEUDLER et al., 1996), este fator pode interferir nas atividades de consumo de metano e na comunidade presente.

Os efeitos dessas mudanças no uso do solo na Amazônia já foram demonstrados para alguns grupos microbianos, Taketani e Tsai (2010) apontaram mudanças na estrutura das comunidades de arquéias oxidadoras de amônia (AOA), após a conversão de floresta para pastagem. Lammel (2011) revela que há sim uma mudança na comunidade microbiana após as modificações no manejo do solo, e sugere que as alterações químicas são fatores importantes para as mudanças ocorridas.

Um trabalho recente realizado na Fazenda Nova Vida, demonstra que a comunidade metanotrófica sofre alterações após a conversação de floresta para pastagem e revela também através do emprego da técnica de PCR em tempo real, que há uma maior abundância de metanotróficas do tipo II em solos de pastagem. Os resultados de pirossequenciamento também confirmam está dominância de metanotróficas do Tipo II, porém em todos os locais estudados, florestas e pastagens (BAEK; NUSSLEIN, 2010.). 
Figura 15 - Árvore filogenética baseada no alinhamento de sequências de aminoácidos do fragmento pmoA amplificado com os primers A189F e mb661R, e sequências referência adquiridas no GeneBank. O método de agrupamento utilizado foi o Neighbor-Joining.

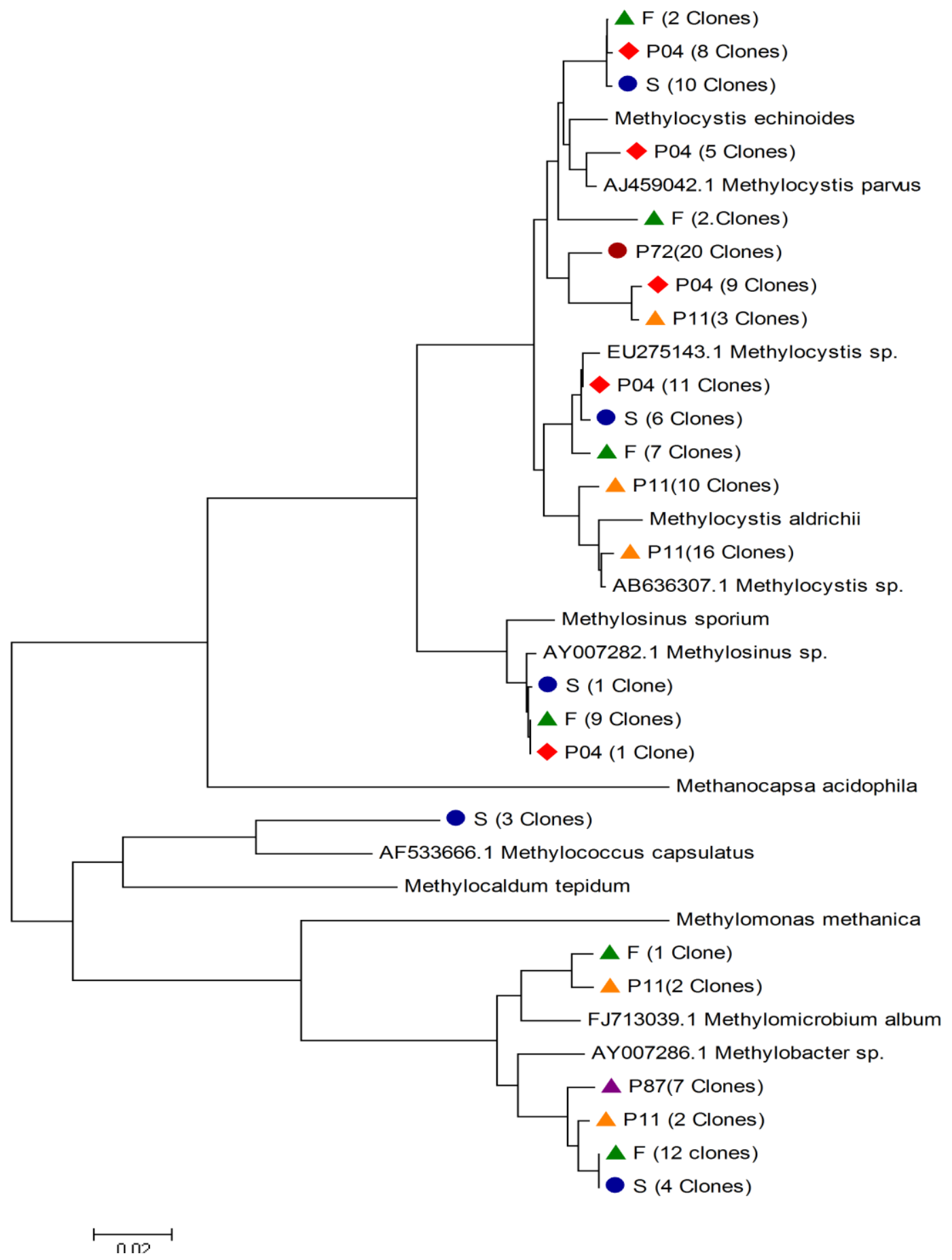




\subsection{Estudo da comunidade ativa para a oxidação de $\mathrm{CH}_{4}$, através do uso da técnica de Stable Isotope Probing (DNA-SIP ${ }^{13} \mathrm{CH}_{4}$ )}

\subsubsection{Enriquecimento}

O experimento de DNA-SIP foi composto por 12 frascos de cultivo, que foram preparados com $5 \mathrm{~g}$ de solo, meio NMS, e enriquecidos com a quantidade aproximada de $10 \%$ de metano na atmosfera. Cinco dos frascos foram alimentados com metano marcado $\left({ }^{13} \mathrm{CH}_{4}\right)$, e cinco com metano não marcado $\left({ }^{12} \mathrm{CH}_{4}\right)$, e os dois frascos restantes utilizados como controle. Os cinco frascos com metano marcado foram denominados $\mathrm{t} 0{ }^{13} \mathrm{C}, \mathrm{t} 1{ }^{13} \mathrm{C}, \mathrm{t} 2{ }^{13} \mathrm{C}$, $\mathrm{t} 3{ }^{13} \mathrm{C}$ e $\mathrm{t} 4{ }^{13} \mathrm{C}$, aqueles incubados com metano não marcado foram denominados $\mathrm{t} 0{ }^{12} \mathrm{C}, \mathrm{t} 1{ }^{12} \mathrm{C}$, $\mathrm{t} 2{ }^{12} \mathrm{C}, \mathrm{t} 3{ }^{12} \mathrm{C}$ e $\mathrm{t} 4{ }^{12} \mathrm{C}$. Os frascos $\mathrm{t} 0{ }^{13} \mathrm{C}$ e $\mathrm{t} 0{ }^{12} \mathrm{C}$ foram sacrificados no momento do início do experimento representando a amostra original. Baseado em estudos anteriores, quando o consumo de metano atingia cerca de $90 \%$ do metano adicionado, os frascos eram realimentados com mais $10 \%$ de metano (CÉBRON et al. 2007a,b; MARTINEAU; WHYTE; GREER, 2010; MORRIS et al., 2002).

A porcentagem de metano adicionada ao enriquecimento está de acordo com o praticado em outros trabalhos, nos quais foram adicionados cerca de $10 \%$ de metano a cada nova alimentação (CÉBRON et al., 2007a, b; MARTINEAU; WHYTE; GREER, 2010; MCDONALD; RADAJEWSKI; MURRELL, 2005; MORRIS et al., 2002).

A adição de NMS ao cultivo pode ter acelerado o processo de oxidação de metano, já que o tempo de incubação foi curto se comparado a outros trabalhos já realizados (CÉBRON et al., 2007a; MARTINEAU; WHYTE; GREER, 2010). Em estudo realizado por Cébron et al. (2007b), as taxas de oxidação de metano foram potencialmente afetadas pela adição de NMS, sendo até duas vezes maiores, se comparadas a cultivos sem adição de NMS. Resultado semelhante também foi encontrado por Martineau, Whyte e Greer (2010), estes observaram que a adição de meio NMS ao cultivo e o aumento da temperatura foram os responsáveis por um aumento significativo da oxidação de metano no solo.

Os resultados apresentados na Figura 16 demonstram que a houve consumo de metano em todos os frascos incubados com $\left({ }^{13} \mathrm{CH}_{4}\right)$ e $\left({ }^{12} \mathrm{CH}_{4}\right)$. O consumo de metano se apresentou rápido e crescente. 
Figura 16- Representação gráfica mostrando a curva de consumo e realimentação $\mathrm{de}^{12} \mathrm{CH}_{4}(\mathrm{a}) \mathrm{e}^{13} \mathrm{CH}_{4}$ (b) dos pares de frascos.
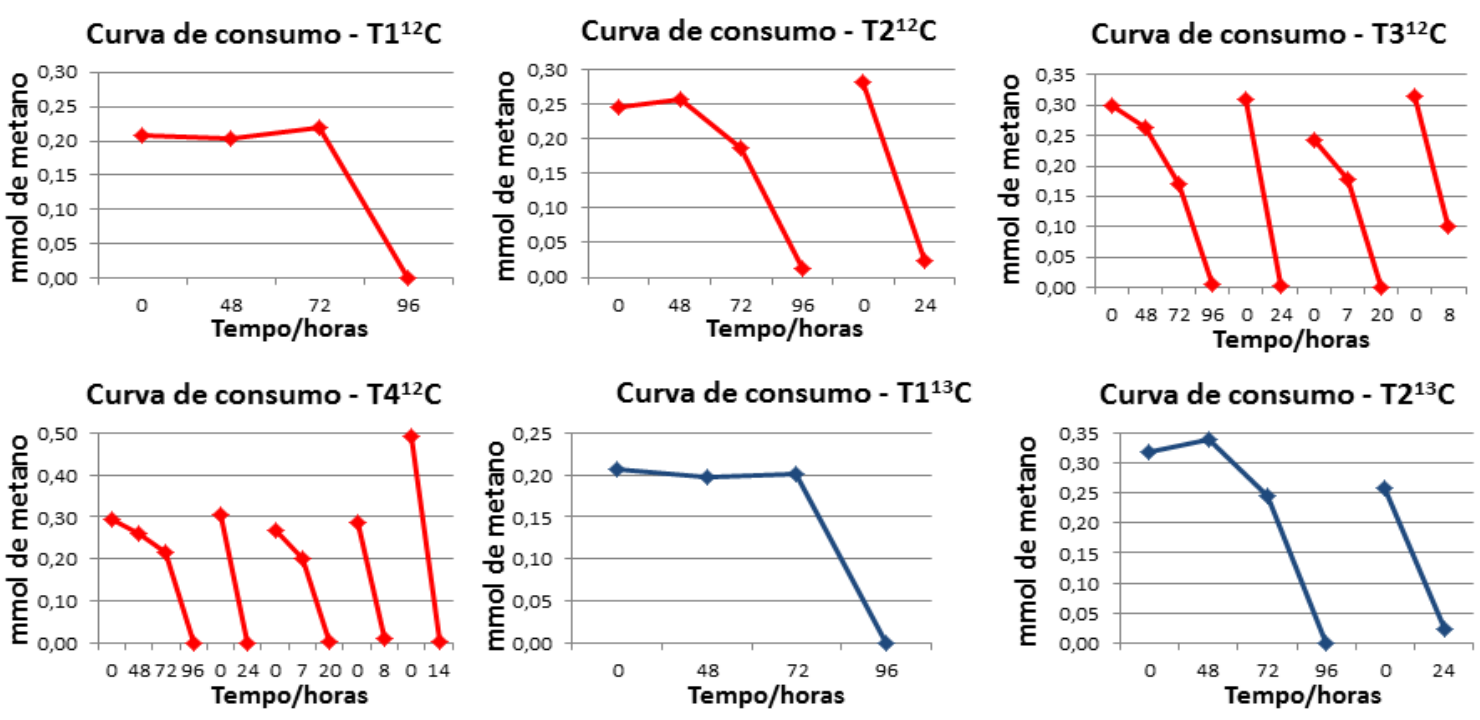

Curva de consumo $-\mathrm{T} 3^{13} \mathrm{C}$

Curva de consumo $-\mathrm{T4}^{13} \mathrm{C}$
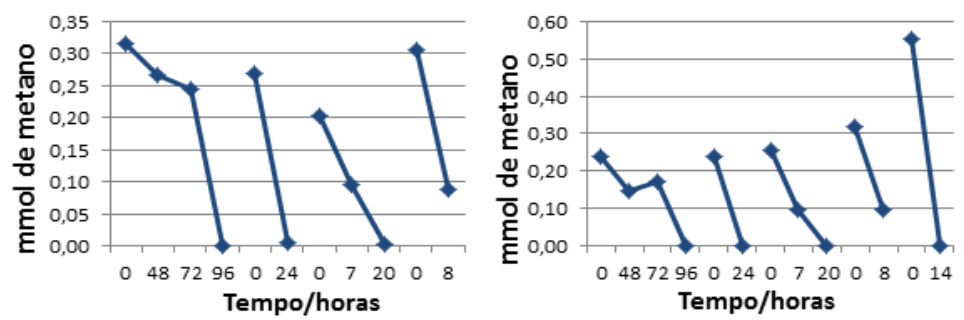

Para recuperar o DNA do material de cada tempo de enriquecimento, um par de frascos (um incubado com ${ }^{13} \mathrm{CH}_{4}$ e outro com ${ }^{12} \mathrm{CH}_{4}$ ) foi sacrificado conforme o consumo atingia um valor acumulado de aproximadamente $0.2,0.6,1.0,1.8 \mathrm{mmol} / \mathrm{mL}$ frasco $(\mathrm{t} 1, \mathrm{t} 2, \mathrm{t} 3 \mathrm{e} \mathrm{t} 4)$. A Figura 17 apresenta o consumo de metano acumulado, em $\mathrm{mmol} / \mathrm{mL}$ por frasco. Visto que os enriquecimentos com ${ }^{13} \mathrm{CH}_{4}$ e ${ }^{12} \mathrm{CH}_{4}$ devem ser considerados equivalentes, o critério para a escolha dos pares de frascos foi a semelhança do consumo acumulado de metano até o momento da próxima retirada. 
Figura 17 - Consumo acumulado de metano em cada frasco de enriquecimento.

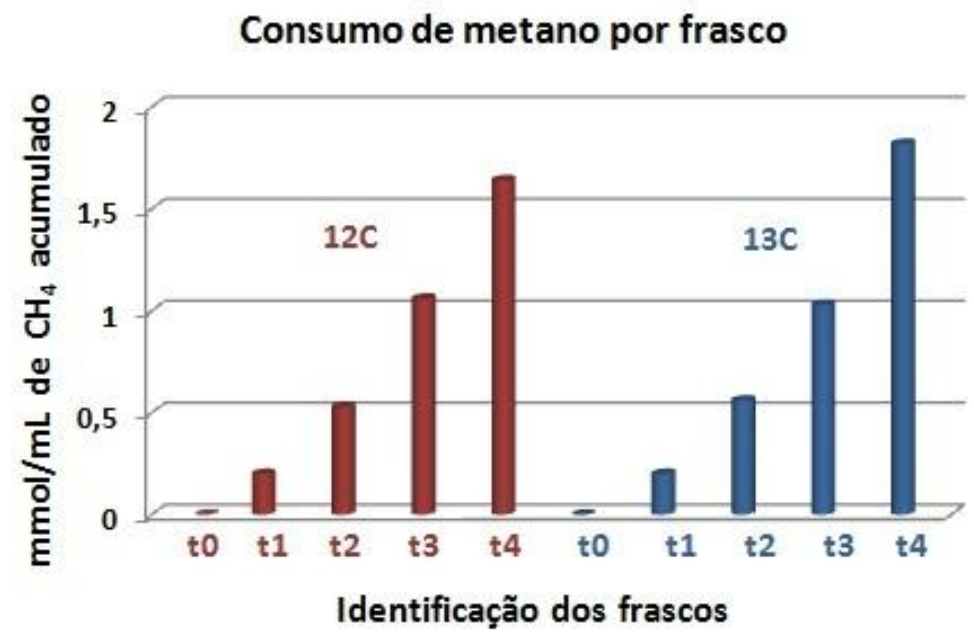

Os frascos foram incubados com ${ }^{12} \mathrm{CH}_{4}$, e incubados com ${ }^{13} \mathrm{CH}_{4}$.

Os frascos foram incubados até atingirem entre 0,2 e $1,8 \mathrm{mmol} / 5 \mathrm{~g}$ de solo de metano acumulado. Trabalhos anteriores relatam a necessidade de um consumo mínimo de metano (0,2 e 1,6 mmol/ $5 \mathrm{~g}$ de solo) para ocorrer a separação das frações de DNA (CÉBRON et al., 2007a, b; MCDONALD; RADAJEWSKI; MURRELL, 2005; MORRIS et al., 2002), e também sugerem evitar longos tempos de incubação para diminuir a chamada alimentação cruzada (cross-feeding) (LINHARES, 2011; MORRIS et al., 2002; NEUFELD; WAGNER; MURRELL, 2007; SAIA et al., 2010).

Depois de realizado o enriquecimento nos diferentes tempos de incubação, o material de cada um dos frascos foi centrifugado. A extração de DNA a partir do recuperado foi realizada utilizando-se o Kit Power lyzer, da MoBio.

\subsubsection{Resultados da ultracentrifugação e fracionamento}

A ultracentrifugação, fracionamento e quantificação do DNA ocorreram conforme descrito na seção 4.6.3. A Figura 18 apresenta os gráficos da distribuição da quantidade absoluta de DNA, em relação à densidade de cada fração, dos pares de frascos alimentados com ${ }^{12} \mathrm{C}$-metano $\left({ }^{12} \mathrm{C}\right.$-DNA) e ${ }^{13} \mathrm{C}$-metano $\left({ }^{13} \mathrm{C}\right.$-DNA $)$, para cada tempo de incubação. 
Figura 18 - Quantidades de DNA normalizadas para cada uma das frações, tanto para as relativas aos enriquecimentos com ${ }^{12} \mathrm{CH}_{4}\left({ }^{12} \mathrm{C}\right.$-DNA linha vermelha), quanto as relativas ao enriquecimento com ${ }^{13} \mathrm{CH}_{4}\left({ }^{13} \mathrm{C}\right.$-DNA linha azul).

(Continua)

a)

DNA recuperado no fracionamento - to

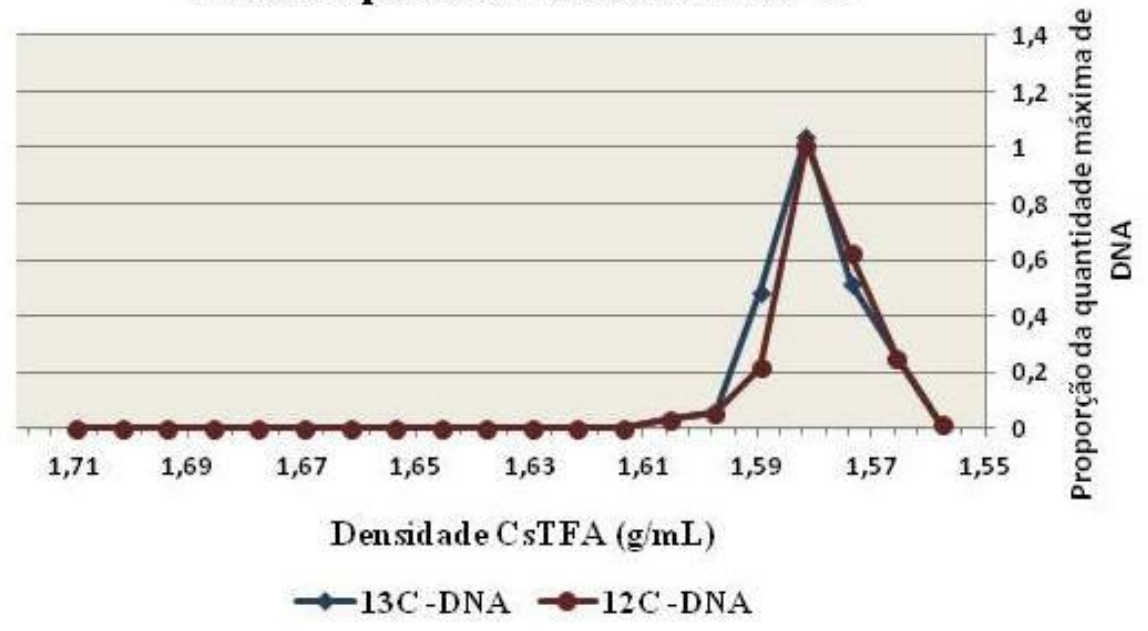

Figura 18-a

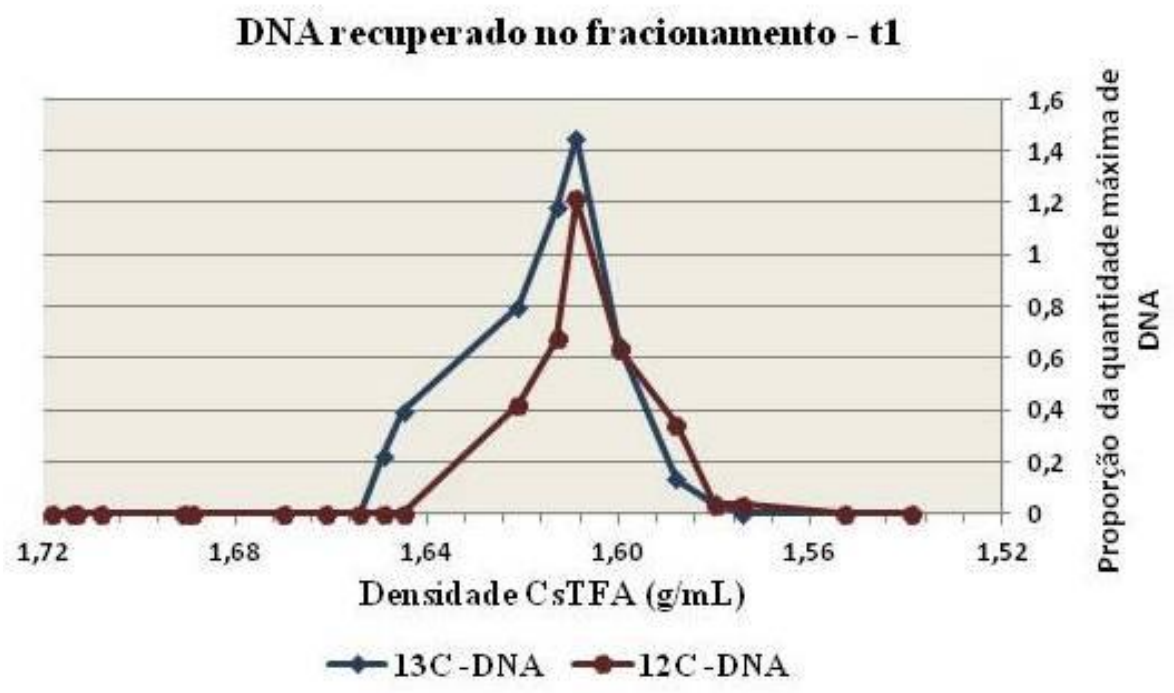

(Continua) 


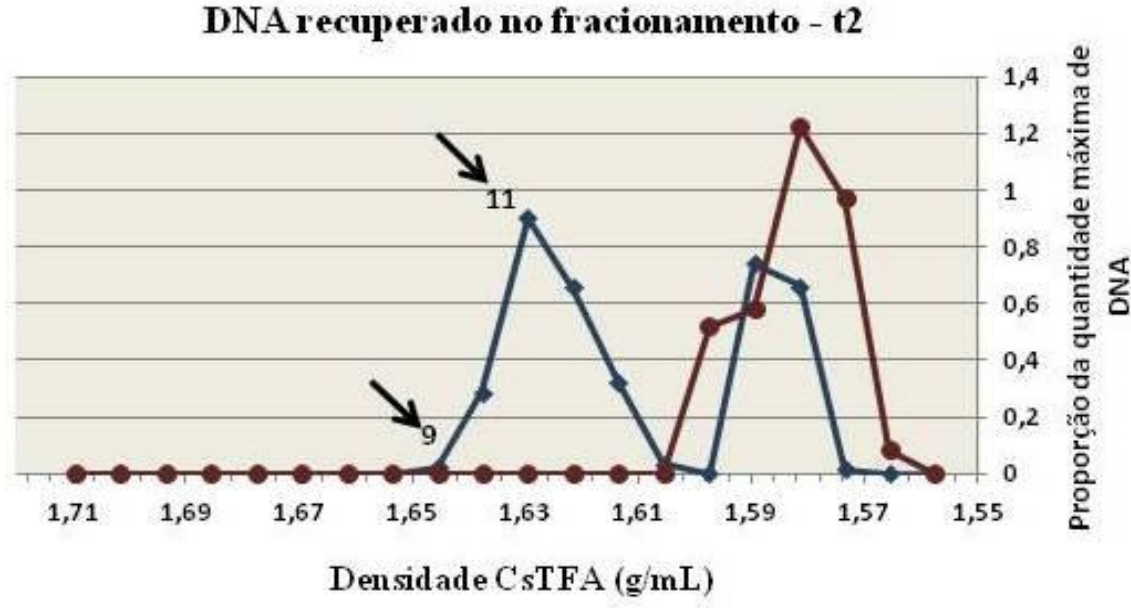

$\multimap 13 \mathrm{C}-\mathrm{DNA} \rightarrow 12 \mathrm{C}-\mathrm{DNA}$

Figura 18-c

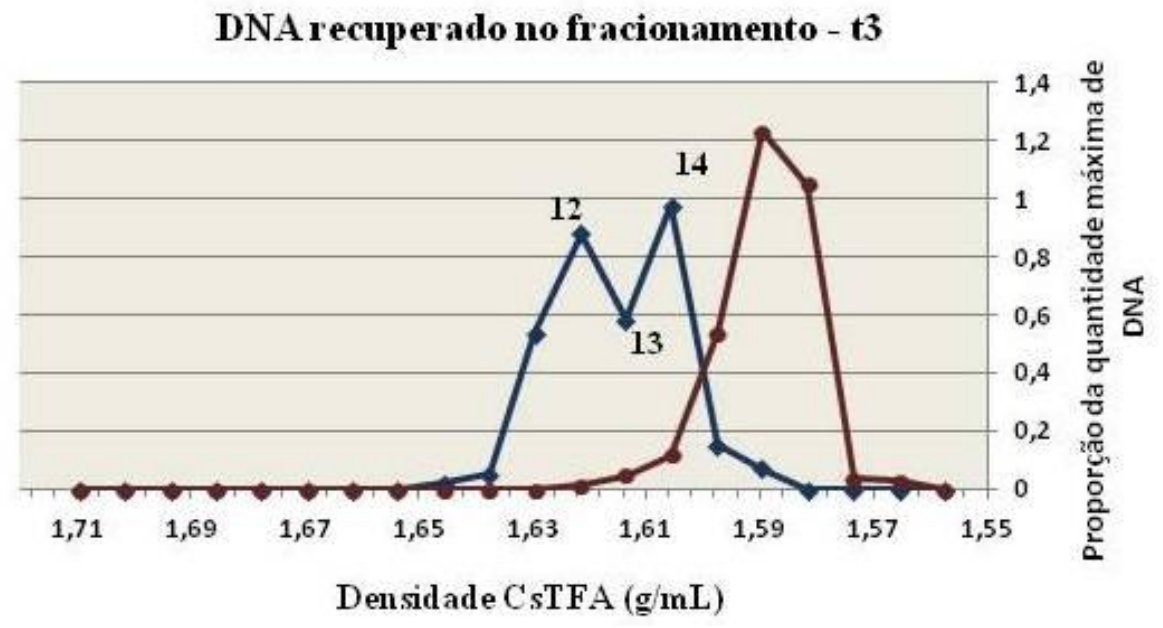

Figura 18-d 
(Conclusão)

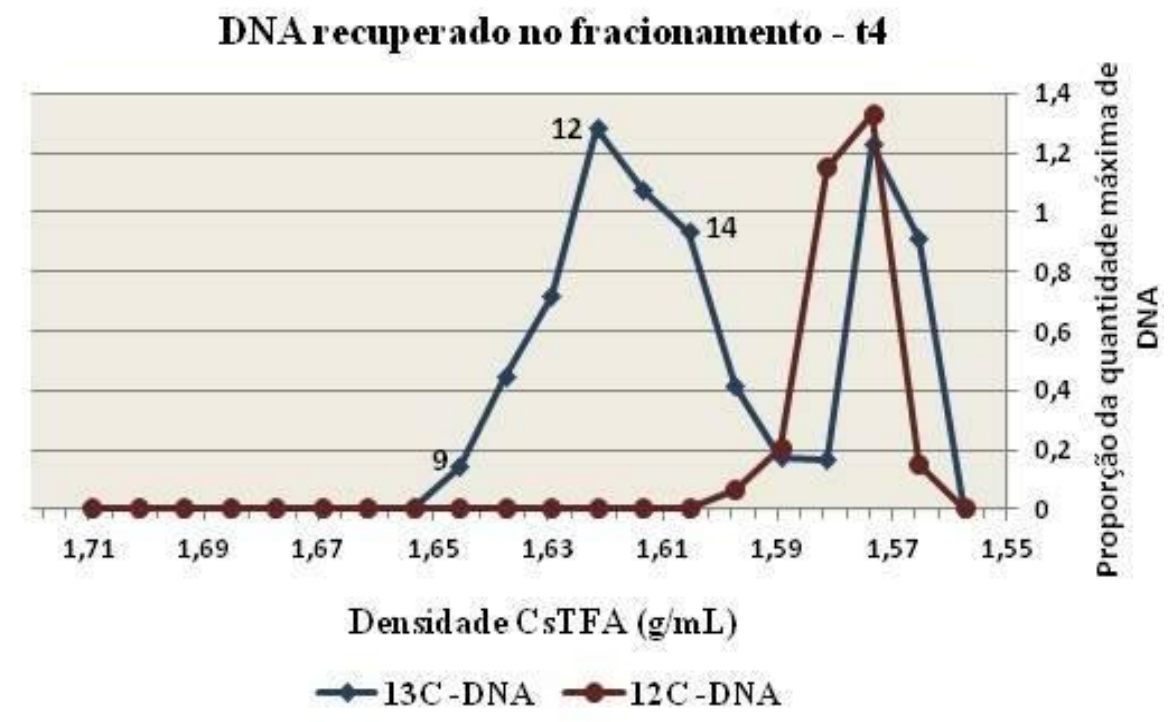

\section{Figura 18-e}

A quantidade de DNA esta apresentada em $\mathrm{pg} / \mathrm{ml}$. Os gráficos dos tempos de 1 a 5 estão representados pelas letras de (a) até (e).

A fração t0 representada na Figura 18 refere-se à amostra original, a qual não sofreu incubação, portanto não apresenta incorporação de metano marcado. A Figura 18b mostra que as distribuições de densidades das frações do ${ }^{12} \mathrm{C}$-DNA e ${ }^{13} \mathrm{C}$-DNA provenientes dos microcosmos no tempo de incubação t1, são praticamente as mesmas, estando a maior quantidade DNA na fração 14, com densidade de 1,609 g/mL. Isso demonstra que o tempo de incubação não foi suficiente para ter ocorrido incorporação do carbono ${ }^{13} \mathrm{CH}_{4}$ no DNA da microbiota.

A incorporação do isótopo $13 \mathrm{C}$ de metano no DNA da microbiota, pode ser observada nas Figuras 18c, 18d e 18e. No t2 (Fig.18c) o ${ }^{13} \mathrm{C}$-DNA ocupou as frações 9 a 18, estando em maior quantidade na fração 11 , com densidade de $1,6295 \mathrm{~g} / \mathrm{mL}$, enquanto que na fração "leve" ( ${ }^{12}$ C-DNA) o DNA ocupou as frações 15 a 19, com densidades variando entre 1,5975 $\mathrm{g} / \mathrm{mL}$ (fração 15 ) e $1,5655 \mathrm{~g} / \mathrm{mL}$ (fração 19). A Figura 18d que se refere ao T3, o ${ }^{13} \mathrm{C}-\mathrm{DNA}$ ocupou as frações 9 a 15, com densidades variando entre 1,6455 g/mL (fração 9) e 1,5895 $\mathrm{g} / \mathrm{mL}$ (fração 15), já o ${ }^{12} \mathrm{C}$-DNA ocupou as frações 12 a 19, com maior quantidade de DNA na fração 15, com densidade de 1,5895g/mL. No t4 (Figura 18e) observamos a incorporação do isótopo 13 de metano nas frações 9 a 19, com maior quantidade de DNA na fração 12 com 
densidade de 1,6215 g/mL. O gráfico mostra que há uma queda nas quantidades de DNA a partir da fração 13 e tornando a aumentar nas frações 18 e 19. A distribuição de densidades na fração leve aparece entre as frações 15 a 19. A maior quantidade de DNA do ${ }^{13} \mathrm{CH}_{4}$ nos tempos t2, t3 e t4 aparecem na fração 12 e as densidades variaram entre as 1,6215 a 1,6295 $\mathrm{g} / \mathrm{mL}$.

A partir destes resultados foram selecionadas frações do t0 e do t2 para a continuação dos estudos. O t0 foi selecionado por representar a amostra original, e o t2 por que foi o primeiro tempo que apresentou clara separação entre as frações leves e pesadas. As demais frações foram descartadas por não terem apresentado separação, caso do t1; ou por possivelmente apresentarem cross-feding, $\mathrm{t} 3$ e $\mathrm{t} 4$.

\subsubsection{Estudos com Biologia Molecular com Material proveniente do SIP}

A fração 17 da amostra original (t0) foi selecionada para construção de biblioteca do gene rRNA 16S, por representar o DNA total extraído do solo da região, já as frações 9 (t2f9) e 11 (t2-f11) foram as escolhidas para representarem o t2 e as frações pesadas $\left({ }^{13} \mathrm{CH}_{4}\right)$. O objetivo de construir as bibliotecas com as frações 9 e 11 do DNA marcado foi acessar a comunidade metabolicamente ativa que oxida metano.

Foram sequenciados 42 clones da biblioteca de DNA da amostra original (t0), 44 clones da biblioteca do DNA da fração 9 pesada (t2-f9), e 41 clones da biblioteca do DNA da fração 11 pesada (t2-f12). As bibliotecas estão apresentadas nas Figuras 19 (t0), 20 (t2-f9) e 21(t2-f11).

Na Figura 19, esta apresentada a árvore filogenética construída a partir da amostra original, e nas Figuras 20 e 21, estão as àrvores construídas a partir do DNA recuperado do enriquecimento com metano marcado, tempo de incubação t2 - fração 9 e 11 . As sequências das três bibliotecas foram classificadas em Filos e o resultado está graficamente apresentado na Figura 22. 
Figura 19 - Árvore filogenética baseada no alinhamento de sequências do gene rRNA 16S, obtidas a partir do DNA da amostra original ( $\mathrm{t} 0$ ). As sequências referência foram adquiridas no GeneBank. O método de agrupamento utilizado foi o Neighbor-Joining.

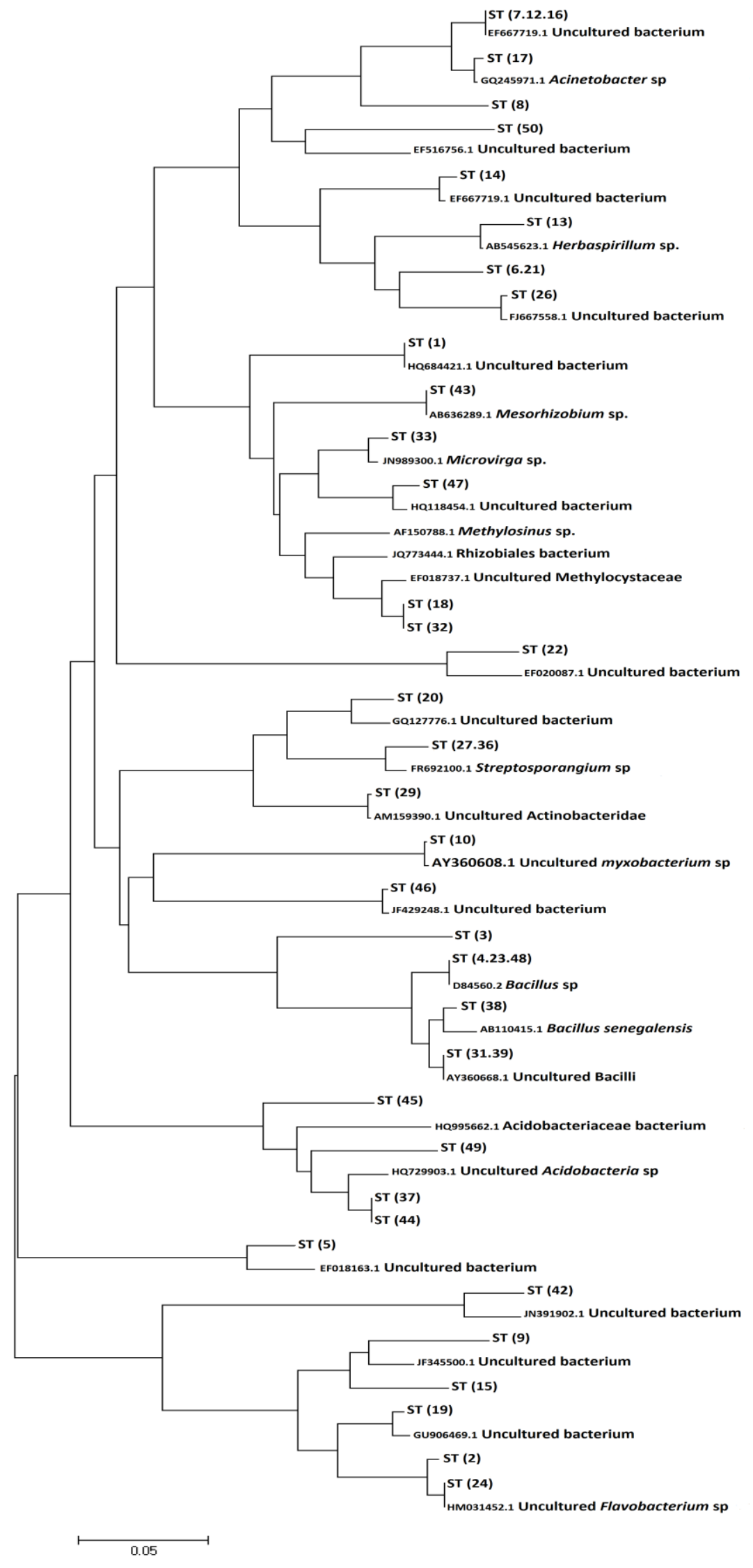


Figura 20 - Árvore filogenética baseada no alinhamento de sequências do gene rRNA 16S, obtidas a partir do DNA recuperado dos enriquecimento com metano marcado, tempo de incubação t2 - fração 9.

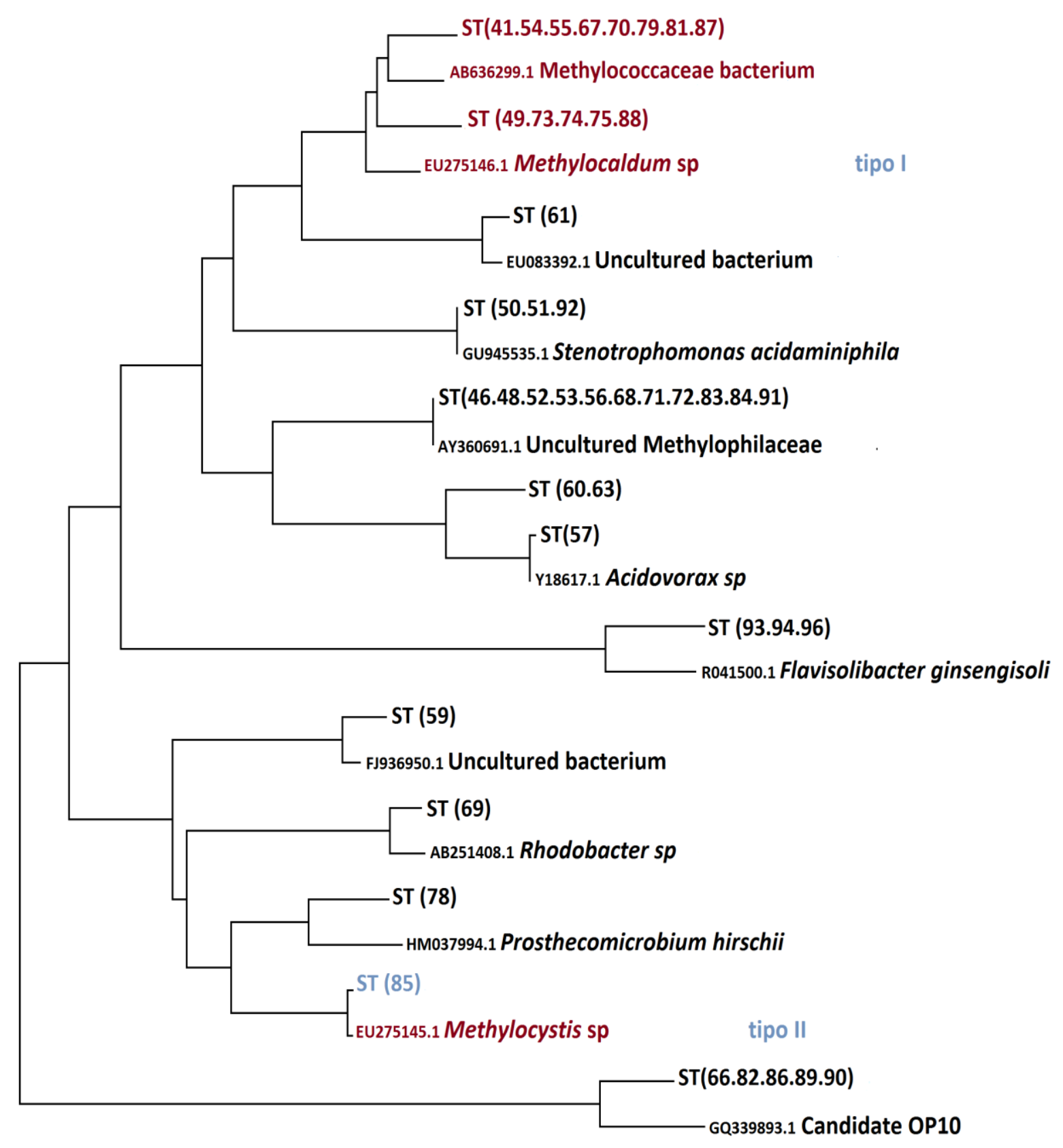

As sequências referência foram adquiridas no GeneBank. O método de agrupamento utilizado foi o Neighbor-Joining. 
Figura 21 - Árvore filogenética baseada no alinhamento de sequências do gene rRNA 16S, obtidas a partir do DNA recuperado dos enriquecimento com metano marcado, tempo de incubação t2 - fração 11 .

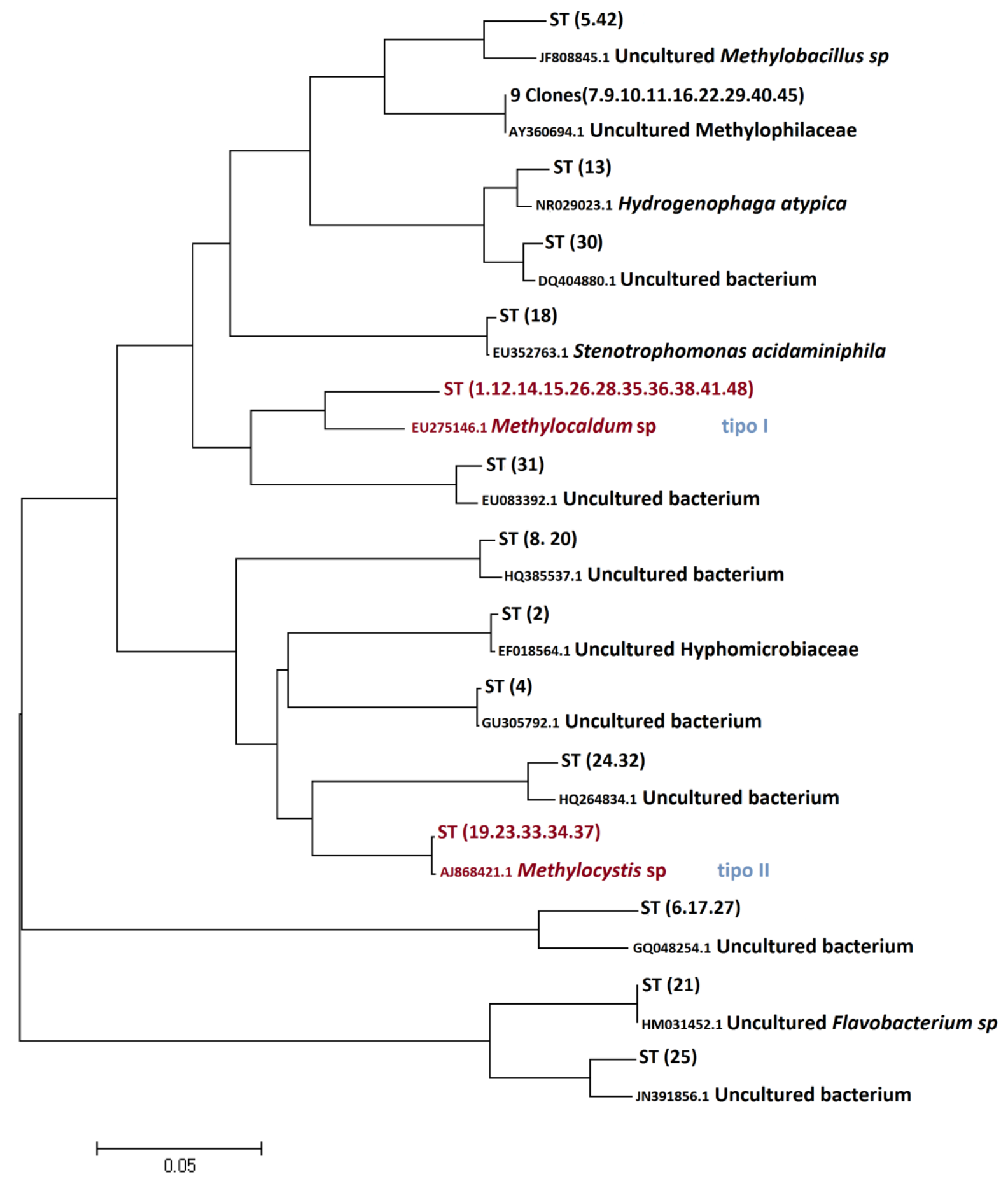

As sequências referência foram adquiridas no GeneBank. O método de agrupamento utilizado foi o Neighbor-Joining. 
Observa-se que a biblioteca construída a partir do DNA total do solo (amostra original t0) apresenta uma diversidade maior de Filos em relação às frações pesadas, o que já era esperado, pois esta biblioteca representa todos os micro-organismos presentes na amostra. Também como esperado, após a incubação com metano houve um aumento no número de Proteobacteria nas frações pesadas $\left({ }^{13} \mathrm{CH}_{4}\right)$, indicando que a técnica atingiu seu objetivo de evidenciar a comunidade ativa utilizando o metano marcado com isótopos estáveis como substrato.

Nas bibliotecas construídas a partir das frações pesadas nota-se a presença em maior quantidade de micro-organismos relacionados diretamente ao ciclo do metano, sendo que, o maior número de clones é composto por metanotróficas das famílias Methylococcaceae e Methylocystaceae, seguido por sequências pertencentes à família Methylophilaceae, ao qual se incluem as metilotróficas não metanotróficas.

As metilotróficas não metanotróficas são capazes de crescer sobre vários substratos de carbono, tais como metanol, aminas metiladas, formaldeído, compostos sulfúricos, entre outros (CHISTOSERDOVA, 2011; HANSON; HANSON; 2006; LIDSTROM, 2006; LUEDERS et al., 2004). Estas já foram detectadas no DNA das frações pesadas de diversos trabalhos envolvendo a técnica de SIP-DNA, uma provável explicação está no fato de que a oxidação do metano pelas bactérias metanotróficas, libera metabolitos que servem de substrato para as metilotróficas (CÉBRON et al., 2007a, b; LUEDERS et al., 2003; MAYUMI et al., 2010; MORRIS et al., 2002; RADAJEWSKI et al., 2002). 
Figura 22 - Distribuição dos Filos detectados no solo da amostra P04, identificados através de três bibliotecas do gene rRNA $16 \mathrm{~S}$.

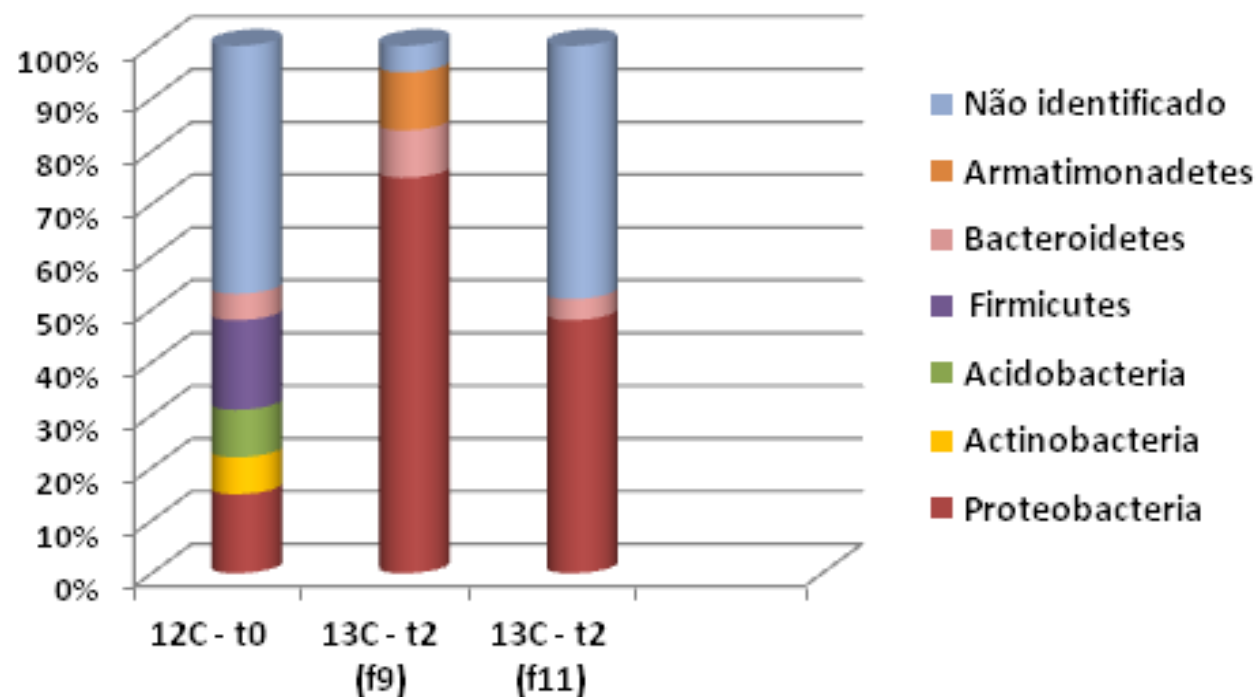

A presença da família Methylophilaceae é um indicativo que pode ter ocorrido crossfeeding, porém de uma forma geral, a ocorrência de grande número de clones que se relacionam às sequências de metanotróficas conhecidas, sugere que a maior parte do DNA das frações pesadas é oriunda de consumidores primários do substrato marcado, e que a incorporação de carbono pesado por outros grupos através de cross-feeding é limitada (MCDONALD; RADAJEWSKI; MURRELL, 2005).

As bibliotecas oriundas do DNA das duas frações pesadas apresentaram resultados diferentes entre elas (Figura 20 e 21). A fração 9 apresenta um maior número de clones do Filo Proteobacteria, seguido de clones do Candidato a Filo OP10 e Bacteroidetes, apresentando poucos clones de não cultivados, enquanto, a fração 11 indica que os clones do Filo Proteobacteria e os clones de não cultivados aparecem com a mesma frequência, não apresentando ainda nenhum clone do candidato a Filo OP10. A obtenção deste resultado pode estar relacionada à densidade flutuante do DNA, que pode variar de acordo com seu teor de Guanina-Citosina (G-C) (CÉBRON et al., 2007b; RADAJEWSKI et al., 2003), ou seja, na fração 9, mais pesada, pode estar ocorrendo maior número de bactérias que possuem elevados teores de G-C em seu DNA.

Ainda em relação às frações pesadas do DNA, nota-se que dentre as sequências de metanotróficas houve uma predominância de clones que se associam gênero Methylocaldum, 
pertencente a família Methylococcaceae (Figuras 20 e 21). Metanotróficas pertencentes ao gênero Methylocaldum já foram encontradas em muitos ambientes, sendo que muitas espécies deste gênero são consideradas termotolerantes, pois possuem crescimento ótimo em temperaturas que variam de 20 a $47{ }^{\circ} \mathrm{C}$ (TROTSENKO et al., 2009). Ainda segundo Trotsenko et al. (2009), estas metanotróficas contêm no seu DNA um teor elevado de G-C (57-58 mol\%).

E importante considerar que a biblioteca do gene pmoA construída a partir do DNA total da amostra P04, mostra uma dominância da família Methylocystaceae (Tabela 2, Figura 15), entretanto, como já citado anteriormente, as bibliotecas construídas a partir do DNA recuperado do enriquecimento com metano marcado, advindo também da amostra P04, demonstra haver uma maior presença de clones pertencentes à família Methylococcaceae. Esta observação pode indicar que metanotróficas pertencentes à família Methylococcaceae estão mais ativas nas condições testadas, e ou ainda estarem relacionadas a fatores como a especificidade do primer.

A construção das bibliotecas do gene rRNA16S das frações do DNA pesado $\left({ }^{13} \mathrm{CH} 4\right)$, permitiu a identificação não apenas de micro-organismos envolvidos tradicionalmente ao ciclo de metano, mas também de organismos pertencentes a outros grupos filogenéticos, como: Bacteroidetes, Armatimonadetes (OP10) e Xanthomonadaceae. Fato este que pode ter ocorrido devido à contaminação da fração pesada pelo gradiente leve (CEBRÓN et al., 2007a).

Estes grupos filogenéticos já foram detectados em outros trabalhos envolvendo a técnica de DNA-SIP. Sequências referentes ao filo Bacteroidetes foram recuperadas das frações do DNA pesado após incubação de solo com ${ }^{13} \mathrm{CH}_{4}$; Sphingobacteriales e Flavobacteriales, estão entre as ordens encontradas que pertencem a este Filo (CÉBRON et al., 2007a; LIN et al., 2004; QIU et al., 2008).

Cébron et al. (2007a), também encontrou sequências relacionadas à família Xanthomonadaceae. Segundo Nercessian et al. (2005), micro-organismos pertecentes ao grupo das Xanthomonadaceae podem estar envolvidos com a utilização de formaldeido e formiato, produtos suscetíveis da oxidação do metano.

Sequências de Rhodobacter também já foram encontradas nas frações pesadas de DNA-SIP que usou metanol como substrato (ANTONY et al., 2010), segundo Meister et al. (2005), este fato pode ocorrer pois células de Rhodobacter podem crescer em acetato.

Dentre os outros clados nos quais agruparam-se sequências de clones da biblioteca da fração pesada, destaca-se aquele formado por representantes do Candidato a Filo OP10. Este 
"candidato" a Filo teve sua existência descoberta através de sequências do gene rRNA 16S, que foram recuperadas de vários ambientes (HUGENHOLTZ; GOEBEL; PACE, 1998), tais como fontes hidrotermais e ambientes vulcanicos (HUGENHOLTZ; GOEBEL; PACE, 1998; STOTT et al., 2008), ambientes hipersalinos (LEY et al., 2006), água doce (WU et al., 2007), ambientes marinhos (INAGAKI et al., 2005) e em solos (CHOW et al., 2002; LESAULNIER et al., 2008).

A fisiologia e o papel ecológico deste grupo ainda não são bem compreendidos (PORTILLO; GONZALEZ, 2009). Os primeiros isolados foram obtidos em 2008 a partir de amostras de solo de fontes geotermais da Nova Zelândia. Segundo descrito por Stott et al. 2008, as colônias eram gram-negativas e apresentavam-se na forma de longas cadeias agregadas na cor avermelhada.

Com propósito de fornecer mais informações sobre distribuição e importância deste grupo no ambiente, Portillo e Gonzales 2009, analisaram sequências de OP10 contidas nos bancos de dados. Com o resultados foi contruída uma árvore filogenética que mostra a posição do grupo dentre os Filos mais representativos do Dominio Bacteria (Figura 23).

Vale lembrar que não foram encontrados relatos de outros trabalhos que empregando a técnica de marcação com isótopos estáveis, tenham recuperado sequências do Candidato a Filo OP10 a partir do DNA da fração pesada. Também ainda não há informações que liguem os organismos de OP10 com o metabolismo do metano, direta ou indiretamente. 
Figura 23 - Árvore filogenética mostrando a posição do Candidato a Filo OP10 dentre os grupos mais representativos do Domínio Bactéria.

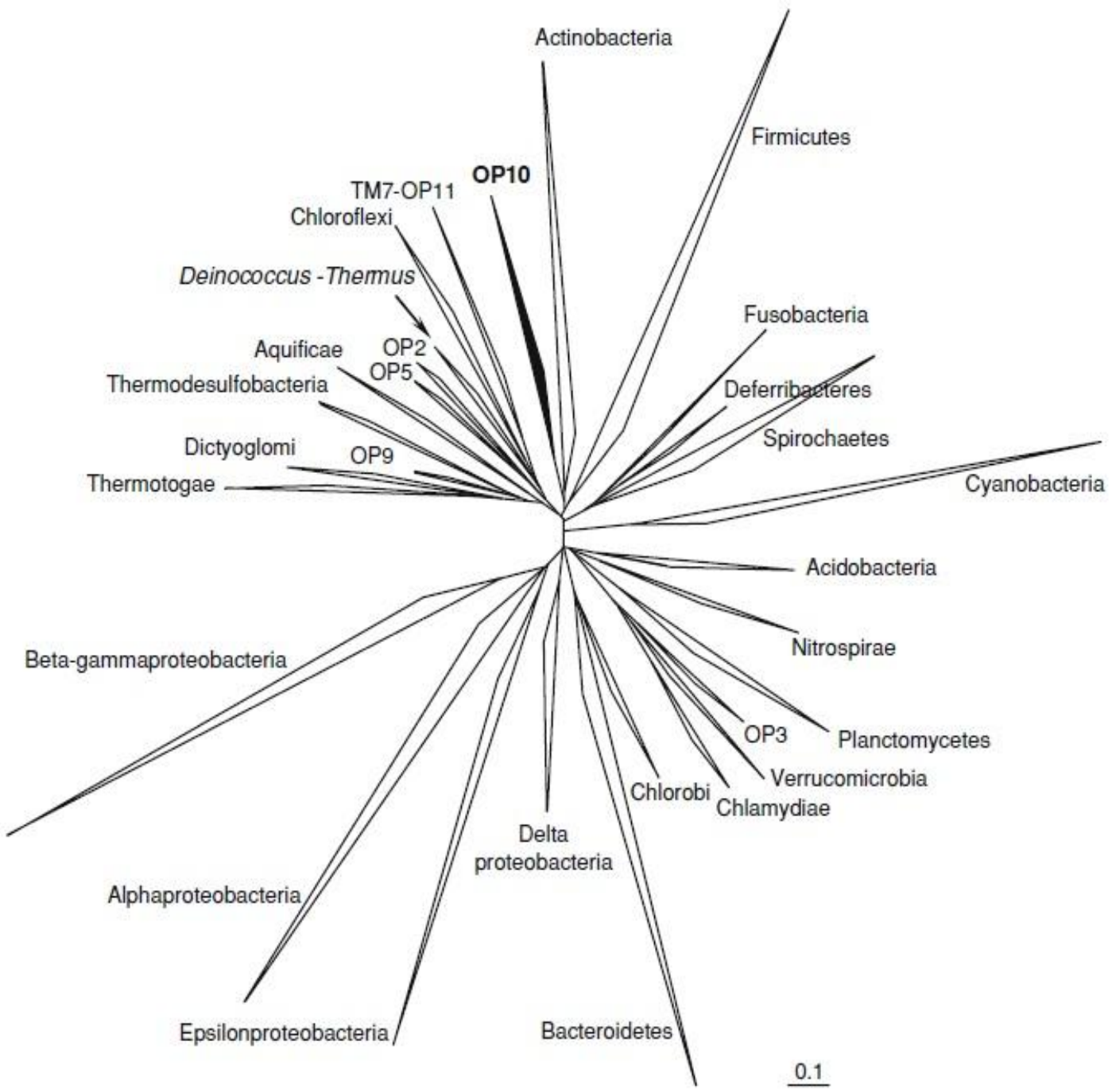

Fonte: Portillo e Gonzalez (2009)

Diante dos resultados obtidos nas bibliotecas construídas a partir do DNA das frações pesadas, que teoricamente representam a comunidade ativa que metaboliza o metano, foram obtidas sequências de organismos já conhecidos por estarem relacionados ao consumo deste gás, mas também foram obtidas sequências de outros micro-organismos que possuem seu papel no ciclo do metano incerto, ou seja, nem é possível sugerir que estão envolvidos de forma direta ou indireta no metabolismo do metano. De qualquer forma, mesmo que o 
consumo do metano não seja direto, a ocorrência destes micro-organismos é de grande importância para o ambiente.

Apesar do crescente empenho científico para compreender as alterações sofridas pelas comunidades microbianas, após a conversão de floresta a pastagem, pouco se sabe sobre quais os impactos destas alterações nas comunidades metanotróficas. As bactérias metanotróficas possuem papel importante na regulação do fluxo líquido de metano entre o solo e a atmosfera (VERCHOT et al., 2000; VISVANATHAN et al., 1999). Diante disso, fica a importância deste trabalho, que contribuiu para o melhor entendimento da estrutura e composição da comunidade metanotrófica na Amazônia. 


\section{CONCLUSÕES}

- As amostras de pastagens (P11, P72 e P04) apresentaram um consumo de metano mais rápido, em relação às amostras de floresta $(\mathrm{F})$ e floresta secundária $(\mathrm{S})$;

- as sequências obtidas a partir das bibliotecas do gene $p m o A$ com amostras de solo de floresta primária, floresta secundária e pastagens, foram relacionadas em sua maioria com sequências pertencentes à família Methylocystaceae;

- a técnica de DNA-SIP possibilitou identificar a comunidade metanotróficas ativa, além de outros grupos de micro-organismos, como os pertencentes à família Methylophilaceae e ao gênero Methylocaldum, além do Filo OP10, cujo papel no ciclo do metano ainda é incerto;

- o protocolo utilizado para a técnica de DNA-SIP com metano marcado, mostrou-se eficiente para o estudo de bactérias metanotróficas. No entanto para a amostra estudada foi verificada a importância de diminuir o tempo de incubação; 


\section{'REFERENCIAS *}

ABELL, G. C. J. et al. Grazing affects methanotroph activity and diversity in an alpine meadow soil. Environmental Microbiology, v. 1, n. 5, p. 457-465, 2009.

AMPE, F. et al. Polyphasic study of the spatial distribution of microorganisms in mexican pozol, a Fermented maize dough, demonstrates the need for cultivation-independent methods to investigate traditional fermentations. Applied and Environmental Microbiology, v. 65, p. 5464-5473, 1999.

ANTONY, C. P. et al. Active methylotrophs in the sediments of Lonar Lake, a saline and alkaline ecosystem formed by meteor impact. The ISME Journal, n. 4, p. 1470-1480, 2010.

ATCC. ATCC medium: 1306 Nitrate mineral salts medium (NMS). Disponível em: <http://www.atcc.org/Attachments/2554.pdf> Acesso em: 5 mar. 2012.

BAANI, M.; LIESACK, W. Two isozymes of particulate methane monooxygenasewith different methane oxidation kinetics are found in Methylocystis sp. strain SC2. Proceedings of the National Academy of Sciences, v. 105, n. 29, p. 10203-10208, 2008.

BAEK, K.H.; NUSSLEIN. K. "Land use alters the structure of methane-oxidizing", The ISME-13, Seattle, WA, 2010.

BALASUBRAMANIAN, R. et al. Oxidation of methane by a biological dicopper centre. Nature, v. 465, p. 115-119, 2010.

BARLAZ, M. A. et al. Evaluation of a biologically active cover for mitigation of landfill gas emissions. Environ. Sci. Technol., v. 38, p. 4891-4899, 2004.

BASTOS, T. X.; DINIZ, T. D. A. S. Avaliação do clima do Estado de Rondônia para desenvolvimento agrícola. Boletim de Pesquisa, n. 44, p. 187-197, 2004.

BENDER, M.; CONRAD, R. Effect of $\mathrm{CH}_{4}$ concentrations and soil sonditions on the Iiduction of $\mathrm{CH}_{4}$ qxidation activity. Soil Biol. Biochem, v. 27, p. 1515-1527, 1994.

BENGTSON, P. et al. Links between methanotroph community composition and $\mathrm{CH} 4$ oxidation in a pine forest soil. FEMS Microbial Ecology, v. 70, n. 3, p. 356-366, 2009.

BENSON, D. A. et al. GenBank. Nucleic Acids Research, v. 33, p. 34-38, 2005.

BODROSSY, L. et al. Analysis of 16S rRNA and methane Monooxygenase gene sequences reveals a novel group of thermotolerant and thermophilic methanotrophs, Methylocaldum gen. nov. Archives Microbiology, v. 168, n. 6, p. 493-503, 1997.

\footnotetext{
*De acordo com:

ASSOCIAÇÃO BRASILEIRA DE NORMAS TÉCNICAS. NBR 6023: informação e documentação: referências: elaboração. Rio de Janeiro, 2002.
} 
BORJESSON, G.; CHANTON, J.; SVENSSON, B. H. Methane oxidation in two Swedish landfill covers measured with carbon-13 to carbon-12 isotope ratios. Journal of Environmental Quality, v. 30, n. 2, p. 369-371, 2001.

BORJESSON, G. et al. Methane oxidation in landfill cover soils, as revealed by potential oxidation measurements and pho spholipid Fatty Acid Analyses. Soil Biol. Biochem., v. 30, p. 1423-1433, 1997.

BOECKX, P.; VAN CLEEMPUT, O.; VILLARALVO, I. Methane Emission from a Landfill and the Methane Oxidising Capacity of its Covering Soil. Soil Biol. Biochem., v. 28, p. 1397$1405,1996$.

BOSCHKER, H. T. S.; MIDDELBURG, J. J. Stable isotopes and biomarkers in microbial ecology. FEMS Microbiology Ecology, v. 1, p. 1334, 2002.

BOWMAN, J. et al. The methanotrophs - the families Methylococcaceae and Methylocystaceae. The Prokaryotes: a handbook on the biology of bacteria. 3rd ed. Singapura: Springer Science, 2006. v. 5, p. 266-289.

BOURNE, D. G.; McDONALD I. R.; MURRELL, J. C. Comparison of pmoA PCR primer sets as tools for investigating methanotroph diversity in three Danish soils. Applied and Environmental Microbiology, v. 67, p. 3802-3809, 2001.

CÉBRON, A. et al. Nutrient amendments in soil DNA Stable Isotope Probing experiments reduce the Ooserved methanotroph diversity. Applied and Environmental Microbiology, v. 73, p. 798-807, 2007a.

CÉBRON, A. et al. Identity of active methanotrophs in landfill cover soil as revealed by DNA stable isotope probing. FEMS Microbial Ecology, v. 62, p. 12-23, 2007 b.

CERRI, C. C. et al. Carbon cycling and sequestration opportunities in South America: the case of Brazil. Soil Use and Management, v. 20, n. special, p. 248-254, 2004.

CERRI, C. E. P. et al. Potential of soil carbon sequestration in Amazonian Tropical Rain Forest. Science, v. 1, n. 1, p. 123-130, 2005.

CONRAD, R. Microbial ecology of methanogens and methanotrophs. Advances in Agronomy, v. 96, p. 1-63, 2007.

CONRAD, R. The global methane cycle: recent advances in understanding the microbial processes involved. Environmental Microbiology Reports, v. 1, p. 285-292, 2009.

COSTELLO, A. M.; LIDSTROM, M. E. Molecular characterization of functional and phylogenetic genes from natural populations of methanotrophs in lake sediments. Applied and Environmental Microbiology, v. 65, p. 5066-5074, 1999.

CHISTOPHERSEN, M. et al. Methane oxidation at low temperature in soil exposed to landfill gas. Jornal Environment Quality. v. 29, n. 6, p. 1989-1997, 2004. 
CRISTOSERDOVA, L. Modularity of methylotrophy, revisited. Environmental Microbiology, v. 13, p. 2603-2622, 2011.

CHOW et al. Molecular characterization of bacterial diversity in Lodgepole pine (Pinus contorta) rhizosphere soils from British Columbia forest soils differing in disturbance and geographic source. FEMS Microbial Ecology, v. 42, p. 347-357, 2002.

DALTON, H. The leeuwenhoek lecture 2000: the natural and unnatural history of methaneoxidizing bacteria. Philosophical transactions of the Royal Society of London: Series B, v. 360, p. 1207-1222, 2005.

DAVIDSON, E. A. et al. The Amazon basin in transition. Nature, v. 481, n. 7381, p. 321$328,2012$.

DEDYSH, S. N. et al. Isolation of acidophilic methane-oxidizing bacteria from northern peat wetlands. Science, v. 282, p. 281-284, 1998.

DEDYSH, S. N. et al. Methylocella palustris gen. nov., sp. nov., a new methane-oxidizing acidophilic bacterium from peat bogs, representing a novel subtype of serine-pathway methanotrophs. International Journal of Systematic and Evolutionary Microbiology, v. 50, p. 955-969, 2000.

DEDYSH, S. N.; KNIEF, C.; DUNFIELD, P. F. Methylocella Species Are Facultatively Methanotrophic. Journal of Bacteriology, v. 187, p. 4665-4670, 2005.

DEDYSH, S. N. et al. Methylocystis heyeri sp. nov., a novel type II methanotrophic bacterium possessing 'signature' fatty acids of type I methanotrophs. International Journal of Systematic and Evolutionary Microbiology, v. 57, p. 472-479, 2007.

DE MORAES, J. F. L. et al. Soil properties under Amazon forest and changes due to pasture installation in Rondonia, Brazil. Geoderma, v. 70, n. 1, p. 63-81, 1996.

DO CARMO, J. B. et al. A source of methane from upland forests in the Brazilian Amazon. Geophysical Research Letters, v. 33, n. 4, 2006.

DORR, N.; GLASSER, B.; KOLB, S. Methanotrophic communities in Brazilian ferralsols from naturally forested, afforested, and agricultural sites. Applied and Environmental Microbiology, v. 76, n. 4, p. 1307-1310, 2010.

DUARTE, R. T. D. Micro-organismos em ambientes criogênicos: gelo glacial, solos expostos por recuo de geleiras, e permafrost polares. 2010. $202 \mathrm{f}$. Tese (Doutorado em Ciências) - Instituto de Ciências Biomédicas, Universidade de São Paulo, São Paulo, 2010.

DUBILIER, N.; BERGIN, C.; LOTT, C. Symbiotic Diversity in Marine Animals: The Art of Harnessing Chemosynthesis. Nature Rev. Microbiology, v. 6, p. 725-740, 2008.

DUNFIELD, P. F. et al. Isolation of a Methylocistis strain containing a novel pmoA-like gene. FEMS Microbiology Ecology, v. 41, p. 17-26, 2002. 
DUNFIELD, P. F. et al. Methylocella silvestris sp. nov. a novel methanotroph isolated from an acidic forest cambisol Printed in Great Britain. International Journal of Systematic and Evolutionary Microbiology, v. 53, p. 1231-1239, 2003.

DUNFIELD, P. F. et al. Methane oxidation by an extremely acidophilic bacterium of the phylum Verrucomicrobia. Nature, v. 450, p. 879-882, 2007.

DUNFORD, E.A; NEUFELD, J.D. DNA stable-isotope probing (DNA-SIP). J.Vis. Exp., 2010.

EINOLA, J. K. M; KETTUNEN, R. H; RINTALA, J. A. Responses of methane oxidation to temperature and water content in cover soil of a boreal landfill. Soil Biol. Biochem., v. 39, p. 1156-1164, 2007.

EINOLA, J. K. M.; KARHU, A. E.; RINTALA, J. A. Mechanically-biologically treated municipal solid waste as a support medium for microbial methane oxidation to mitigate landfill greenhouse emissions. Waste Management, v. 28, p. 97-111, 2008.

ENCICLOPÉDIA BRITANNICA. 2010. Disponível em: <http://www.britannica.com/globalwarning>. Acesso em: 6 jun. 2012.

ESHINIMAEV, B. T.; KHMELENINA, V. N.; TROTSENKO, Y. N. First isolation of a Type II methanotroph from a soda lake. Microbiology, v. 77, p. 628-631, 2008

FEIGL, B. J.; CERRI, C. C.; BERNOUX, M. Balanço de carbono e biomassa microbiana em solos da Amazônia. In: MELO, I. S.; AZEVEDO, J. L. Ecologia Microbiana. Jaguariúna: Embrapa-CNPMA, 1998, p. 423-441.

FERNANDES, S. A. P. et al. Seasonal variation of soil chemical properties and $\mathrm{CO} 2$ and CH4 fluxes in unfertilized and P-fertilized pastures in an Ultisol of the Brazilian Amazon. Geoderma, v. 107, p. 227-241, 2002.

FERREIRA, L. V.; VENTICINQUE. E.; ALMEIDA. S. O desmatamento na Amazônia e a importância das áreas protegidas. Dossiê Amazonia Barsielira I. Estudo Avançado, v. 19, n. $53,2005$.

FELSKE, A. et al. Direct ribosome isolation from soil to extract bacterial rRNA for community analysis Microbiology, v. 62, p. 4162-4167, 1996.

FOLEY, J. A. et al. Global consequences of land use. Science, v. 309, p. 570-574, 2005.

FRANKENBERG, C. et al. Assessing methane emissions from global space-borne observations. Science, v. 308, p. 1010-1014, 2005.

GALFORD, G. L. et al. Historical carbon emissions and uptake from the agricultural frontier of the Brazilian Amazon. Ecological Applications, v. 21, n. 3, p. 750-763, 2011.

GRAHAM, D. W. et al. Factors affecting competition between type I and type II methanotrophs in two-organism continuous flow reactors. Microbial Ecology, v. 25, p. 1-17, 1993. 
HALL, T. A. et al. BioEdit: a user-friendly biological sequence alignment editor and analysis. Nucleic Acids Symposium Series, v. 41, p. 95-98, 1999.

HAKEMIAN, A. S.; ROSENZWEIG, A. C. The biochemistry of methane oxidation. Annual Reviews Biochemistry, v. 76, p. 223-241, 2007.

HAKEMIAN, A, S. et al. The metal centers of particulate methane monooxygenase from Methylosinus trichosporium OB3b. Biochemistry, v. 47, p. 6793-6801, 2008.

HANSON, R. S. ; HANSON, T. E. Methanotrophic bacteria. Microbiological Review, v. 60, n. 2, p. 439-471, 1996.

HARTMAN, W. H. et al. Environmental and anthropogenic controls over bacterial communities in wetland soils. Proc. Natl. Acad. Sci. USA, v. 105, p. 17842-17847, 2008.

HEYER, J. et al. Methylohalobius crimeensis gen. nov., sp. nov., a moderately halophilic, methanotrophic bacterium isolated from hypersaline lakes of Crimea. International Journal of Systematic and Evolutionary Microbiology, v. 55, p. 1817-1826, 2005.

HERPIN, U. et al. Biogeochemical dynamics following land use change from forest to pasture in a humid tropical area (Rondonia, Brazil): a multi-element approach by means of XRFspectroscopy. Science of the Total Environment, v. 286, n. 1-3, p. 97-109, 2002.

HENCKEL, T.et al. Molecular analyses of novel methanotrophic communities in forest soil that oxidize atmospheric methane. Applied and Environmental Microbiology, v. 66, n. 5, p. 1801-1808, 2000.

HOLMES, A. J. et al.Characterization of methanotrophic bacterial populations in soils showing atmospheric methane uptake. Applied Enviromental Microbiology, v. 65, p. 33123318, 1999.

HOLMES, A. J. et al. Evidence that particulate methane monooxygenase and ammonia monooxygenase may be evolutionarily related. Fems Microbiology Letters, v. 132, p. 203208, 1995.

HUGENHOLTZ, P.; GOEBEL, M.; PACE, N. Impact of culture - independent studies on the emerging phylogenetic view of bacterial diversity. Journal Bacteriology, v. 180, n. 8, p. 4765-4774, 1998.

HUMER, M.; LECHNER, P. Design of landfill cover layerto enhance methane oxidation results of two year field investigation. Proceedings Sardinia, p. 541-550, 2001.

IGUCHI, H.; YURIMOTO, H.; SAKAI, Y. Methylovulum miyakonense gen. nov., sp. nov., a type I methanotroph isolated from forest soil. International Journal of Systematic and Evolutionary Microbiology, v. 61, p. 810-815, 2011.

INAGAKI, F. et al. Biogeographical distributionand diversity of microbes in methane hydratebearing deep marine sediments on the Pacific Ocean margin. Proc. Natl. Acad. Sci., v. 103, p. 2815-2820, 2005. 
INSTITUTO DE PESQUISA AMBIENTAL DA AMAZÔNIA - IPAM. Disponível em: <http://www.ipam.org.br/>. Acesso em: 3 abr. 2012.

INSTITUTO NACIONAL DE PESQUISAS ESPACIAIS - INPE. Amazônia: desflorestamento. Disponível em: <http://www.inpe.br/>. Acesso em: 8 mar. 2012.

INTERGOVERNMENTAL PANEL ON CLIMATE CHANGE (IPCC). Fifth assessment report of the intergovernmental panel on climate change. UK: Cambridge University Press, 2007.

ISLAM, T. et al. Methane oxidation at 55 o $\mathrm{C}$ and $\mathrm{pH} 2$ by a thermoacidophilic bacterium belonging to the Verrucomicrobia phylum. Proceedings of the National Academy of Sciences, v. 105, p. 300-304, 2008.

JESUS, E. C. et al. Changes in land use alter the structure of bacterial communities in Western Amazon soils. The ISME Journal, p. 1-8, 2009.

KALYUZHNAYA, M. G. et al. Methylosarcina lacus sp . nov ., a methanotroph from Lake Washington, Seattle, USA, and emended description of the genus Methylosarcina. International Journal of Systematic and Evolutionary Microbiology, v. 55, p. 2345-2350, 2005.

KAUFFMAN, J. B.; CUMMINGS, D. L.; WARD, D. E. Fire in the Brazilian Amazon 2.Biomass, nutrient pools and losses in cattle pastures. Oecologia, v. 113, n. 3, p. 415-427, 1998.

KIGHTHEY, D; NEDWELL, D.; COOPER, M. Capacity for methane oxidation in landfill cover soils measured in laboratory-scale soil microcosms. Applied and Environmental Microbiology, v. 61, p. 592-601, 1996.

KIPERSTOK, A. et al. Prevenção da poluição. Brasília: SENAI, 2002.

KOLB, S. The quest for atmospheric methane oxidizers in forest soils. Environmental Microbiology, v. 5, p. 336-346, 2009.

KNIEF, C.; LIPSKII, A.; DUNFIELD, P. F. Diversity and activity of methanotrophic bacteria in different upland soils. Applied and Environmental Microbiology, v. 69, p. 6703-6714, 2003.

KNIEF, C.; DUNFIELD, P. F. Response and adaptation of different methanotrophic bacteria to low methane mixing ratios. Environmental Microbiology, v. 7, n. 9, p. 1307-1317, 2005.

KNOBLAUCH, C. et al. Methane turnover and temperature response of methane-oxidizing bacteria in permafrost-affected soils of northeast Siberia. Soil Biol. Biochemical, v. 40, p. 3004-3013, 2008.

KRUSCHE, A. V. et al. Efeitos das mudanças do uso da tera na biogeoquímica doscorpos d'água da bacia do rio Ji-Paraná, Rondônia. Acta Amazônica, v. 35, n. 2, p. 197-205, 2005. 
LAMMEL, D. R. Soil microbiota related to carbon, nitrogen and greenhouse gas cycles across different land uses in Southwestern Amazonia. 2011. 151 f. Tese (Doutorado em Ciências) - Centro de Energia Nuclear na Agricultura, Universidade de São Paulo, São Paulo, 2011.

LANE, D. J. 16S/23S rRNA sequencing. In: STACKEBRANDT, E.; GOODFELLOW, M. Nucleic acid techniques in bacterial systematics. Chichester: Wiley. 1991, p. 115- 175.

LEE, T. K.; LEE, J.; SUL, W. J.; IWAI, S.; CHAI, B.; TIEDJE, J. M.; PARK, J. Novel biphenyl-oxidizing bacteria and dioxygenase genes from a korean tidal mudflat. Applied and Environmental Microbiology, v. 77, p. 3888-3891, 2011.

LESAULNIE, C. et al. Elevated atmospheric $\mathrm{CO}_{2}$ affects soil microbial diversity associated with trembling aspen. Environmental Microbiology, v. 10, p. 926-941, 2008.

LEY, R. E. et al. Unexpected diversity and complexity of the Guerrero Negro hypersaline microbial mat. Applied Environmental Microbiol, v. 72, p. 3685-3695, 2006.

LIEBERMAN, R. L.; ROSENZWEIG, A. C. Crystal structure of a membrane-bound metalloenzyme that catalyses the biological oxidation of methane. Nature, v. 434, p. 177-182, 2005.

LIDSTROM, M. E. Methylotrophs: genetics and commercial applications. Annual Review of Microbiology, v. 44, p. 27-58, 1990.

LIDSTROM, M. E. Aerobic methylotrophic procaryotes. The Prokaryotes, v. 2, p. 618-634, 2006.

LIOTTI, R. G. Ocorrência de bactérias metanotróficas em amostras de aterro sanitário através da determinação do pontencial de oxidação do metano e da caracterização de cultura enriquecidas. 2007. Dissertação (Mestrado em Ciências) - Instituto de Ciências Biomédicas, Universidade de São Paulo, São Paulo, 2007.

LINDNER, A. S. et al. Methylocystis hirsuta sp. nov., a novel methanotroph isolated from a groundwater aquifer. International Journal of Systematic and Evolutionary Microbiology, v. 57, p.1891-1900, 2007.

LINHARES, D. C. Estudo da comunidade metanotrófica em amostras do manguezal de Bertioga, Estado de São Paulo, através da técnica de marcação de ácidos nucléicos com isótopos estáveis (SIP-DNA). 2011. 112 f. Dissertação (Mestrado em Ciências) Departamento de Microbiologia, Universidade de São Paulo, São Paulo, 2011.

LUEDERS, T. et al. Stable isotope probing of rRNA and DNA reveals a dynamic ethylotroph community and trophic interactions with fungi and protozoa in oxic rice field soil. Environmental Microbiology, v. 6, p. 60 -72, 2004.

MAECK, M. et al. Sensitivity of the denaturing gradient gel electrophoresis technique in detection of known mutations and novel Asian mutations in the CFTR gene. Human Mutation, v. 9, p. 136-147, 1997. 
MALDANER, L. S. Cobertura para oxidação biológica do metano em aterros de resíduos sólidos urbanos. 2011. 109 f. Dissertação (Mestrado em Engenharia) - Escola Politécnica, Universidade de São Paulo, São Paulo, 2011.

MALHI, Y. R. et al. The regional variation of aboveground live biomass in old-growth Amazonian forests. Global Change Biol., v. 12, n. 7, p. 1107-1138, 2006.

MARTINEAU, C.; WHYTE, L.; GREER, C. Stable Isotope Probing Analysis of the Diversity and Activity of Methanotrophic Bacteria in Soils from the Canadian High Arctic. Applied Environmental Microbiology, v. 76, n. 17, p. 5773-5784, 2010.

MAYUMI, D. et al. Seasonal change in methanotrophic diversity and populations in a rice field soil assessed by DNA-Stable Isotope Probing and Quantitative Real-Time PCR. Microbies Environmental, v. 25, n. 3, p. 156-163, 2010.

MEISTER, M. et al. L-Malyl-Coenzyme A Methylmalyl-Coenzyme A Lyase is involved in Acetate assimilation of the isocitrate Lyase-Negative Bacterium Rhodobacter capsulatus.

Journal of Bacteriology, v. 187, n. 4, p.1415-1425, 2005.

MENYAILO, O. V. et al. Changing land use reduces soil $\mathrm{CH} 4$ uptake by altering biomass and activity but not composition of high-affinity methanotrophs. Global Change Biology, v. 10, p. 2405-2419, 2008.

MOHANTY, S. R. et al. Differential effects of nitrogenous fertilizers on methane-consuming microbes in rice field and forest soils. Applied and Environmental Microbiology, v. 72, p. 1346-1354, 2006.

MOREIRA, F. M. S.; SIQUEIRA, J. O. Os organismos do solo. Microbiologia e bioquímica do solo. Lavras: UFLA, 2006. Cap. 2.

MORRIS, S. et al. Identification of the functionally active methanotroph population in a peat soil microcosm by stable-isotope probing. Applied and Environmental Microbiology, v. 68, p. $1446-1453,2006$.

MORTATTI, J. et al. Biogeochemistry of the Madeira river basin. GeoJournal, v. 19, n. 4, p. 391-397, 1989.

MURREL, J. C.; RADAJEWSKI, S. Cultivation-independent technique for studying methanotroph ecology. Microbiological Research, v. 151, p. 807-814, 2000.

MURREL, J. C.; MACDONAL, I.R.; BOURNE, D. G. Molecular Methods for the study of methanotroph ecology. Fems Microbiology-Ecology, v. 27, p. 103-114, 1998.

MUYZER, G.; DE WAAL, E. C.; UITTERLINDEN, A. G. Profiling of complex microbial populationsby denaturing gradient gel electrophoresis analysis of polymerase chain reactionamplified genes coding for 16S rRNA. Applied and Environmental Microbiology, v. 59, p. 695-700,1993. 
MUYZER, G.; SMALLA, K. Application of denaturing gradient gel electrophoresis (DGGE) and temperature gradient gel electrophoresis (TGGE) in microbial ecology. Antonie Van Leeuwenhoek International Journal of General and Molecular Microbiology, v. 73, p. 127- 141, 1999.

MCDONALD, I. R.; RADAJEWSKI, S.; MURRELL, J. C. Stable isotope probing of nucleic acids in methanotrophs and methylotrophs : A review. Organic Geochemistry, v. 36, p. 779-787, 2005

NAKAYAMA, C. R. et al. Revealing archaeal diversity patterns and methane fluxes in Admiralty Bay, King George Island, and their association to Brazilian Antarctic Station activities. Deep Sea Research Part II: Topical Studies in Oceanography, v. 58, p. 128-138, 2011.

NEILL, C. et al. Soil Carbon and nitrogen stocks following forest clearinh for pasture in the south western Brasilian Amazon. Ecological Applications, v. 7, n. 4, p. 1216- 1225, 1997.

NEILL, C. et al. Rates and controls of nitrous oxide and nitric oxide emissions following conversion of forest to pasture in Rondonia. Nutrient Cycling in Agroecosystems, v. 71, n. 1, p. 1-15, 2005.

NEPSTAD, D.C. et al. Interactions among Amazon land use, forests and climate: prospects for a near-term forest tipping point. Philos. Trans. R. Soc. B, v. 363, p. 1737-1746, 2008.

NEUFELD, J. D. et al. DNA stable-isotope probing. Nature Protocols, v. 2, n. 4, p. 860-866, 2007.

NERCESSIAN, O. et al. Diversity of functional genes of methanogens, methanotrophs and sulfate reducers in deep-sea hydrothermal environments. Environmental Microbiology, v. 7, p. 118-132, 2005.

NEUFELD, J.; WAGNER, M.; MURRELL, C. Who eats what, where and when? Isotopelabelling experiments are coming of age. The ISME Journal, v. 1, p. 103-110, 2007.

NUSSLEIN, K.; TIEDJE, J. M. Soil Bacterial Community Shift Correlated with Change from Forest to Pasture Vegetation in a Tropical Soil. Applied and Environmental Microbiology, v. 65, p. 3622-3626, 1999.

OP DEN CAMP, H. J. M. et al. Environmental, genomic and taxonomic perspectives on methanotrophic Verrucomicrobia. Environmental Microbiology, p. 293-306, 2009.

PAULA, F. S. Diversidade e estrutura funcional de comunidades microbianas em solos da Amazônia e resposta a mudança na forma de uso do solo. 2012. $107 \mathrm{f}$. Tese (Doutorado em Ciências) - Departamento de Microbiologia, Universidade de São Paulo, São Paulo, 2012.

PAPATHEODOROU, E. M.; EFTHIMIADOU, E.; STAMOU. G. P. Diversity of soil bacteria as affected by management practices and phenological stage of Phaseolus vulgaris. European Journal of Soil Biology, v. 44, p. 429-436, 2008. 
POL, A. et al. Methanotrophy below $\mathrm{pH} 1$ by a new Verrucomicrobia species. Nature, v. 450, p. 874-879, 2007.

PORTILLO, M. C.; GONZALEZ, J. M. Members of the Candidate Division OP10 are spread in a variety of environments. World J Microvial Biotechnol, v. 25, p. 347-353, 2009.

QIU, Q. et al. Applying stable isotope probing of phospholipid fatty acids and rRNA in a Chinese rice field to study activity and composition of the methanotrophic bacterial communities. The ISME Journal, v. 2, p. 602-614, 2008.

RADAJEWSKI, S. et al. Stable-isotope probing as a tool in microbial ecology. Nature, v. 403, p. 646-649, 2000.

RADAJEWSKI, S. et al. Identification of active methylotroph populations in an acidic forest soil by stable - isotope probing. Microbiology, v. 148, p. 2331-2342, 2002.

RADAJEWSKI, S.; MCDONALD, I. R..; MURRELL, J. C. Stable-isotope probing of nucleic acids: a window to the function of uncultured microorganisms. Curr. Opin. Biotechnol., v. 14, p. 296-302, 2003.

RAGHOEBARSING, A. A. et al. Methanotrophic symbionts provide carbon for photosynthesis in peat bogs. Nature, v. 436, p. 1153-1156, 2005.

RAHALKAR, M. et al. Methylosoma difficile gen . nov ., sp . nov ., a novel methanotroph enriched by gradient cultivation from littoral sediment of Lake Constance Printed in Great Britain. International Journal of Systematic and Evolutionary Microbiology, v. 57, p. 1073- 1080, 2007.

RASTOGI, G. et al. Novel methanotroph diversity evidenced by molecular characterization of particulate methane monooxygenase A (pmoA) genes in a biogas reactor. Microbiol. Research, v. 164, p. 536-544, 2009.

REEVE, J. R. et al. Effects of soil type and farm management on soil ecological functional genes and microbial activities. The ISME Journal, v. 4, n. 9, p. 1099-1107, 2010.

ROESCH, L. F. et al. Pyrosequencing enumerates and contrasts soil microbial diversity. The ISME Journal, v. 1, n. 4, p. 283-290, 2007.

RONDÔNIA (Estado). Secretaria de Estado do Desenvolvimento Ambiental. Núcleo de Sensoriamento Remoto e Climatologia. Boletim climatológico de Rondônia - 2002. Porto Velho, 2003. 25 p.

SAIA, F. T. et al. Desenvolvimento das técnicas de DNA-Stable Isotope Probing (SIP) para identificar dinâmicas e populações microbianas e seus genes funcionais responsáveis pela degradação de compostos orgânicos em amostras ambientais. São Paulo: Instituto Oceanográfico, Universidade de São Paulo, 2010. 62 p. Disponível em: <http://www.prosabmicrobiologia.org.br/rede/manuais.> Acesso em: 8 mar. 2011. 
SANTOS, H. F. et al. Mangrove bacterial diversity and the impact of oil contamination revealed by pyrosequencing: bacterial proxies for oil pollution. PLoS One, v. 6, p. 16943, 2011.

SEMRAU, J. D.; DISPIRITO, A.; YOON, S. Methanotrophs and copper. FEMS Microbiology Reviews, v. 34, p. 496-531, 2010.

SINGH, B. K. et al. Effect of afforestation and reforestation of pastures on the activity and population dynamics of Methanotrophic bacteria. Applied and Environmental Microbiology, p. 5153-5161, 2007.

SINGH, B. K. et al. Soil methane oxidation and methanotroph responses to afforestation of pastures with Pinus radiata stands. Soil Biology \& Biochemistry, p. 2196-2205, 2009.

SOARES-FILHO, B. S. et al. Modelling conservation in the Amazon basin. Nature. v. 440, p. 520-523, 2006.

SCHLOSS, P. D. et al. Introducing mother: Open source, platform-independet, communitysupported software for describing and comparing microbial communites. Applied and Environmental Microbiology, v. 75, p. 7537-7541-2009.

SIQUEIRA, J. F.; SAKAMOTO, M.; ROSADO, A. S. Microbial community profiling using terminal restriction fragment length polymorphism (T-RFLP) and denaturing gradient gel electrophoresis (DGGE). Methods in Molecular Biology, v. 666, p. 71-85, 2010.

SMITH, P. Modeling soil carbon dynamics in tropical ecosystems. Nutr. Cycling Agroecosyst, p. 341-364, 2000.

SMITH, S. M. et al. Crystal structure and characterization of particulate methane monooxygenase from Methylocystis species strain M. Biochemistry, v. 50, p. 10231-10240, 2011.

STEENBERGH1, A. K. et al. Biphasic kinetics of a methanotrophic community is a combination of growth and increased activity per cell. Fems Microbiology Ecology, v. 71, n. 1, p. 12-22, 2010.

STEUDLER, P. A. et al. Consequence of forest-to-pasture conversion on $\mathrm{CH} 4$ fluxes in the Brazilian Amazon Basin. Journal of Geophysical Research, v. 101, n. D13, p. 18547-18554, 1996.

STOECKER, K. B. et al. Cohn's Crenothrixis a filamentous methane oxidizer with and unusual methane monooxygenase. Proc. Natl. Acad. Scie., v. 103, p. 2363-2367, 2006.

STOTT, M. B. et al. Isolation of novel bacteria, including a candidate division, from geothermal soils in New Zealand. Environmental Microbiology, v. 10, p. 2030-2041, 2008.

TATE, K. R. et al. Postharvest patterns of carbon dioxide production, methane uptake and nitrous oxide production in a Pinus radiata D. Don plantation. Forest Ecology and Management, v. 228, p. 40-50, 2006. 
TATE, K. R. et al. Methane uptake in soils from Pinus radiata plantations, a reverting shrubland and adjacent pastures: effects of land-use change, and soil texture, water and mineral nitrogen. Soil Biology \& Biochemistry, v. 39, p. 1437-1449, 2007.

TAMURA, K. et al. MEGA 4: Molecular Evolutionary Genetics Analysis (MEGA) software version 4.0. Molecular Biology and Evolution, v. 24, p. 1596-1599, 2007.

TAKETANI, R. G. et al. Characterisation of the effect of a simulated hydrocarbon spill on diazotrophs in mangrove sediment mesocosm. Antonie van Leeuwenhoek, v. 96, p. 343-354, 2009.

TAKETANI, R. G.; TSAI, S. M. The influence of different land uses on the structure of archaeal communities in Amazonian anthrosols based on 16S rRNA and amoA Genes. Microbial Ecology, v. 59, n. 4, p. 734-743, 2010.

TATE, K.R.; WALCROFT, A. On-farm biofilters offer reduced methane emissions to partly offset the environmental footprint. In: CURRIE, L. D.; LINDSAY, C. L. (Ed.). Nutrient management in a rapidly changing world: fertilizer and lime research centre, New Zealand Massey University, Palmerston North. 2009. p. 36-46. (Occasional Report, n. 22).

TEIXEIRA, L. C. R. S.; PEIXOTO, R. S.; CURY, J. C.; SUL, W. J.; PELLIZARI, V. H.; TIEDJE, J.; ROSADO, A. S. Bacterial diversity in rhizosphere soil from Antarctic vascular plants of Admiralty Bay, maritime Antarctica. The ISME Journal, v. 4, p. 989-1001, 2010.

TORVES, J. C. Estudo de micro-organismos metanotróficos responsáveis pela oxidação de metano em coberturas de aterros sanitários. 2006. 118 f. Dissertação (Mestrado em ciências) - Departamento de Biotecnologia, Universidade de Caxias do Sul, Caxias do Sul, 2006.

TROTSENKO, Y. A. et al. Thermophilic and thermotolerant aerobic methanotrophs Microbiology, v. 78, n. 4, p. 387-401, 2009.

TOUROVA, T. P. et al. The phylogenetic position of Methylobacter psychrophilus sp. nov. Microbiology, v. 68, p. 493-495, 1999.

THIES, J. E. Soil microbial community analysis using terminal restriction fragment length polymorphisms. Soil Science Society of America Journal, v. 71, n. 2, p. 579-591, 2007.

TSUBOTA, B. T. Methylothermus thermalis gen. nov., sp. nov., a novel moderately thermophilic obligate methanotroph from a hot spring in Japan Printed in Great Britain.

International Journal of Systematic and Evolutionary Microbiology, v. 55, p. 1877-1884, 2005.

VERCHOT, L. V. et al. Land-use change and biogeochemical controls of methane fluxes in soils of eastern Amazonia. Ecossystems, v. 3, p. 41-56, 2000.

VIGLIOTTA G. E. et al. Clonothrix fusca Roze 1896, a filamentous, sheathed, methanotrophic proteobacterium. Applied and Environmental Microbiology, v. 73, p.35563565, 2007. 
VISVANATHAN, C. et al. Methanotrophic activities in tropical landfill cover soils: effects of temperature, moisture content and methane concentration. Waste Management \& Research, v. 17, n. 4, p. 313-323, 1999.

WARD, D.; WELLER, R.; BATESON, M. 16S rRNA sequences reveal numerous uncultured microorganisms in a natural community. Nature, v. 345, p. 63-65, 1990.

WARTIAINEN, I. et al. Methylocystis rosea sp. nov., a novel methanotrophic bacterium from Arctic wetland soil. International Journal of Systematic and Evolutionary Microbiology, v. 56, p. 541-547, 2006.

WILSON, K. Preparation of genomic DNA from bacteria. In: AUSUBEL, F. M. (Ed.). Current protocols in molecular biology. Massachusetts: John Wiley \& Sons, Inc., 2001. p. 241-245.

WISE, M. G.; MCARTHUR, J. V.; SHIMKETS, L. J. Methanotroph diversity in landfill soil: Isolation of novel type I and type II methanotrophs whose presence was suggested by cultureindependent 16S ribossomal DNA analysis. Applied and Environmental Microbiology, v. 65, n. 1, p. 4887-4897, 1999.

WU, L. et al. Microarray-based analysis of subnanogram quantities of microbial community DNAs by using whole-community genome amplification. Applied and Environmental Microbiology, v. 72, n. 7, p. 4931-4941, 2006.

WU, X. et al. Bacterial community composition of a shallow hypertrophic freshwater lake in China, revealed by 16S rRNA gene sequences. FEMS Microbiol Ecology, v. 61, p. 85-96, 2007.

YIN, B. et al. Bacterial functional redundancy along a soil reclamation gradient. Applied and Environmental Microbiology, v. 66, n. 10, p. 4361-4365, 2000.

ZEISS, C. A. (2006). Accelerated methane oxidation cover system to reduce greenhouse gas emissions from MSW landfills in cold, semi-arid regions. Water, Air, and Soil Pollution. v. 176. pp. 285-306. 


\section{APÊNDICES}

\section{APÊNDICE A - Preparo do meio de cultura NMS}

O preparo no meio NMS requer a mistura de várias soluções que devem ser esterilizadas separadamente, pois precipitam quando são misturadas antes da esterilização em autoclave.

Tabela A.1- Composição e preparo do meio de cultura NMS

\begin{tabular}{ll}
\hline Reagentes & Quantidade \\
\hline Solução B & $150 \mathrm{~mL}$ \\
Solução C & $100 \mathrm{~mL}$ \\
Solução de CaCl2 & $20 \mathrm{~mL}$ \\
Solução de Fe & $2 \mathrm{~mL}$ \\
Solução Traço de metais & $0,5 \mathrm{~mL}$ \\
Água Milli-Q & $478 \mathrm{~mL}$ \\
\hline
\end{tabular}

\section{$\underline{\text { Modo de Preparo }}$}

Esterilizar em autoclave $727 \mathrm{~mL}$ de água Milli-Q, em frasco de reagente com capacidade para 1L. Adicionar as demais soluções, já estéreis, misturando com movimentos suaves a cada adição.

Fonte: Adaptado de ATCC (2011)

Tabela A.2 - Composição e preparo da Solução B

\begin{tabular}{ll}
\hline Reagentes & Quantidade \\
\hline Na2HPO4. 7H2O & $0,537 \mathrm{~g}$ \\
KH2PO4 & $0,272 \mathrm{~g}$ \\
Aguá Milli-Q & $150 \mathrm{~mL}$ \\
\hline
\end{tabular}

\section{$\underline{\text { Modo de Preparo }}$}

Em um frasco com tampa, misturar os reagentes em água, e esterilizar em autoclave. Dissolver os elementos e armazenar em temperatura ambiente.

Tabela A.3 - Composição e preparo da Solução C 


\begin{tabular}{ll}
\hline Reagentes & Quantidade \\
\hline MgSO4.7H2O & $1 \mathrm{~g}$ \\
KNO3 & $1 \mathrm{~g}$ \\
\hline Aguá Milli-Q & $100 \mathrm{~mL}$ \\
\hline
\end{tabular}

\section{$\underline{\text { Modo de Preparo }}$}

Em um frasco com tampa, misturar os reagentes a água Milli-Q, e esterilizar em autoclave.

Dissolver os elementos e armazenar em temperatura ambiente.

Tabela A.4 - Composição e preparo da Solução de Cloreto de Cálcio

\begin{tabular}{ll}
\hline Reagentes & Quantidade \\
\hline CaCl2 & $1 \mathrm{~g}$ \\
Aguá Milli-Q & $100 \mathrm{~mL}$ \\
\hline
\end{tabular}

$\underline{\text { Modo de Preparo }}$

Em um frasco com tampa, misturar os reagentes a água Milli-Q, e esterilizar em autoclave.

Dissolver os elementos e armazenar em temperatura ambiente.

Tabela A.5 - Composição e preparo da Solução de Ferro Quelado

\begin{tabular}{ll}
\hline Reagentes & Quantidade \\
\hline EDTA & $0,2 \mathrm{~g}$ \\
Cloreto de Ferro III & $0,5 \mathrm{~g}$ \\
HCL concentrado & $0,3 \mathrm{~mL}$ \\
Água Milli-Q & $100 \mathrm{~mL}$ \\
\hline
\end{tabular}

\section{$\underline{\text { Modo de Preparo }}$}

Em um frasco com tampa, misturar os reagentes a água Milli-Q, e esterilizar a solução por filtração através de sitema Millipore com membrana $22 \mu \mathrm{m}$, e acondicionar em frasco envolvido com papel alumínio e a temperatura ambiente. 
Tabela A.6 - Composição e preparo da solução traço de metais

\begin{tabular}{|c|c|}
\hline Reagentes & Quantidade \\
\hline $\mathrm{FeSO}_{4 .} 7 \mathrm{H}_{2} \mathrm{O}$ & $20,0 \mathrm{mg}$ \\
\hline $\mathrm{ZnSO}_{4} 7 \mathrm{H}_{2} \mathrm{O}$ & $1,0 \mathrm{mg}$ \\
\hline $\mathrm{H}_{3} \mathrm{BO}_{3 .} 4 \mathrm{H}_{2} \mathrm{O}$ & $3,0 \mathrm{mg}$ \\
\hline $\mathrm{MnCl}_{2 .} 7 \mathrm{H}_{2} \mathrm{O}$ & $0,3 \mathrm{mg}$ \\
\hline $\mathrm{CoCl}_{2} .6 \mathrm{H}_{2} \mathrm{O}$ & $2,0 \mathrm{mg}$ \\
\hline $\mathrm{CaCl}_{2} .2 \mathrm{H}_{2} \mathrm{O}$ & $0,1 \mathrm{mg}$ \\
\hline $\mathrm{NiCl}_{2 .} 6 \mathrm{H}_{2} \mathrm{O}$ & $0,2 \mathrm{mg}$ \\
\hline $\mathrm{Na}_{2} \mathrm{MoO}_{4} 2 \mathrm{H}_{2} \mathrm{O}$ & $0,3 \mathrm{mg}$ \\
\hline Água Milli-Q & $100 \mathrm{~mL}$ \\
\hline
\end{tabular}

$\underline{\text { Modo de Preparo }}$

Em um frasco com tampa, misturar os reagentes a água Milli-Q, e esterilizar em autoclave.

Acondicionar em frasco envolvido com papel alumínio e a temperatura ambiente. 


\section{APÊNDICE B - Parâmetros físico-químicos}

Tabela B.1. Os parâmetros C e N estão expressos em g. $\mathrm{Kg}^{-1}$; Matéria Orgânica (MO)está expressa em g.dm ${ }^{-3} ; \mathrm{Al}^{+3}$ está expressos em mmol c.dm

${ }^{3}, \mathrm{P}, \mathrm{S}, \mathrm{B}, \mathrm{Cu}$ estão expressos em mg.dm ${ }^{-3} ; \mathrm{K}^{+}, \mathrm{Ca}^{+2}, \mathrm{Mg}^{+3}$ estão expressos em mmolc. $\mathrm{dm}^{-3}$.

\begin{tabular}{|c|c|c|c|c|c|c|c|c|c|c|c|c|c|}
\hline Amostras & $\mathbf{C}$ & $\mathbf{N}$ & $\mathrm{C} / \mathrm{N}$ & MO & pH & $\mathbf{P}$ & $\mathbf{S}$ & $\mathbf{K}^{+}$ & $\mathrm{Ca}^{+2}$ & $\mathbf{M g}^{+3}$ & $\mathrm{Al}^{+3}$ & B & $\mathrm{Cu}$ \\
\hline F 1 & 11,05 & 0,76 & 14,50 & 16 & 3,9 & 5 & 9 & 0,8 & 10 & 3 & 1 & 0,19 & 0,9 \\
\hline F10 & 8,73 & 0,72 & 12,14 & 32 & 4,5 & 7 & 10 & 1,1 & 14 & 10 & 3 & 0,22 & 1 \\
\hline F100 & 11,45 & 1,04 & 11,02 & 17 & 3,6 & 5 & 11 & 0,6 & 7 & 2 & 3 & 0,24 & 1,9 \\
\hline P04 1 & 32,3 & 1,64 & 19,69 & 17 & 4,5 & 3 & 9 & 0,6 & 6 & 2 & 1 & 0,15 & 1,3 \\
\hline P04 10 & 8,76 & 0,55 & 15,86 & 14 & 4,6 & 3 & 9 & 1,1 & 6 & 3 & 2 & 0,14 & 1,4 \\
\hline P04 100 & 5,12 & 3,20 & 16,02 & 48 & 5 & 4 & 10 & 1,5 & 30 & 6 & 0,01 & 0,2 & 1,4 \\
\hline P72 1 & 11,95 & 0,67 & 17,89 & 25 & 4 & 5 & 8 & 1,3 & 9 & 2 & 2 & 0,17 & 1 \\
\hline P72 10 & 16,8 & 1,08 & 15,62 & 28 & 4,6 & 4 & 8 & 1,5 & 9 & 2 & 2 & 0,17 & 1,4 \\
\hline P72 100 & 22,05 & 1,36 & 16,18 & 28 & 4,6 & 3 & 8 & 0,5 & 16 & 2 & 2 & 0,14 & 1,8 \\
\hline P11 1 & 25,30 & 1,69 & 14,94 & 42 & 4,8 & 7 & 11 & 1,2 & 18 & 9 & 1 & 0,16 & 2,3 \\
\hline P11 10 & 29,15 & 2,13 & 13,67 & 37 & 5 & 6 & 13 & 2,4 & 19 & 9 & 0,01 & 0,16 & 2,1 \\
\hline P11 100 & 62,80 & 4,83 & 12,99 & 57 & 5 & 10 & 12 & 1,4 & 36 & 14 & 0,01 & 0,21 & 2,4 \\
\hline S 1 & 12,05 & 1,09 & 11,02 & 19 & 4 & 6 & 13 & 0,9 & 7 & 3 & 4 & 0,22 & 0,7 \\
\hline 10 & 16,80 & 1,52 & 11,08 & 14 & 3,7 & 5 & 14 & 0,8 & 3 & 2 & 7 & 0,24 & 0,8 \\
\hline S100 & 13,80 & 1,17 & 11,76 & 21 & 4,4 & 5 & 9 & 0,8 & 13 & 4 & 1 & 0,16 & 0,4 \\
\hline
\end{tabular}

